\title{
COMPARAÇÃO DA ANÁLISE DE CONFORTO DE FRENAGEM SUBJETIVA $x$ OBJETIVA DE UM VEÍCULO DE PASSEIO
}

Trabalho de Conclusão de Curso apresentado à Escola Politécnica da Universidade de São Paulo para obtenção do título de Mestre em Engenharia Automotiva. (Mestrado Profissionalizante) 


\title{
COMPARAÇÃO DA ANÁLISE DE CONFORTO DE FRENAGEM SUBJETIVA $x$ OBJETIVA DE UM VEÍCULO DE PASSEIO
}

\begin{abstract}
Trabalho de Conclusão de Curso apresentado à Escola Politécnica da Universidade de São Paulo para obtenção do título de Mestre em Engenharia Automotiva. (Mestrado Profissionalizante)
\end{abstract}

Área de Concentração: Engenharia Automotiva

Orientador: Prof. Dr. Tarcisio Antonio Hess Coelho 
Este exemplar foi revisado e alterado em relação à versão original, sob responsabilidade única do autor e com a anuência de seu orientador.

São Paulo, 16 de dezembro de 2005.

Assinatura do autor

Assinatura do orientador

FICHA CATALOGRÁFICA

Kawaguchi, Hiroaki

Comparação da análise de conforto de frenagem subjetiva $X$ objetiva de um veículo de passeio / H. Kawaguchi. -- ed.rev. -São Paulo, 2005.

$101 p$.

Trabalho de curso (Mestrado Profissionalizante em Engenharia Automotiva). Escola Politécnica da Universidade de São Paulo.

1.Automóveis 2.Freios 3.Frenagem 4.Conforto veicular I.Universidade de São Paulo. Escola Politécnica II.t. 
À minha esposa Ana Cristina, pelo incentivo, paciência e colaboração nos momentos difíceis.

Ao meu pai e a minha mãe (póstuma), pela dedicação e incentivo à minha educação e aperfeiçoamento profissional. 


\section{AGRADECIMENTOS}

Ao meu amigo e orientador, Prof. Dr. Tarcisio Antonio Hess Coelho, pelo grande apoio, paciência e incentivo na elaboração deste trabalho.

Aos meus amigos Geraldo José Gardinalli e Carlos Börder, pelo incentivo, apoio e compromisso durante todo o curso do mestrado profissional e em especial, na elaboração deste trabalho final.

À TRW Automotive - Chassis Systems, em especial, aos meus amigos Aparecido Zanarelli, Marcelo Arronilas Fernandes, Sérgio Roberto Berteloni e Maércio Aparecido Gachet pela colaboração na obtenção de material e dos dados experimentais para elaboração deste trabalho.

À Robert Bosch - Chassis Systems, em especial ao meu amigo Paulo Lourente pela colaboração na obtenção de informações para elaboração deste trabalho.

A todos que, direta ou indiretamente, colaboraram na execução deste trabalho. 


\section{SUMÁRIO}

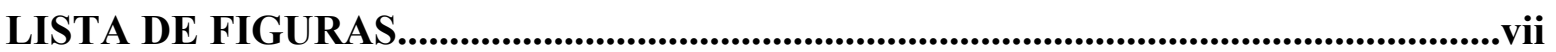



LISTA DE ABREVIATURAS E SIGLAS...................................................................xii

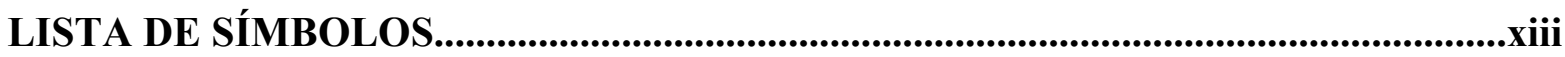

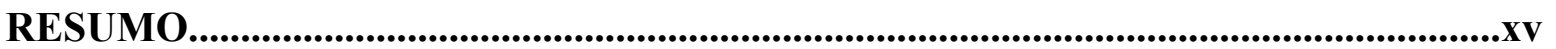

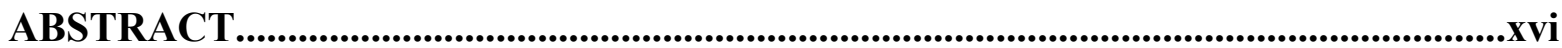

1. INTRODUÇÃ

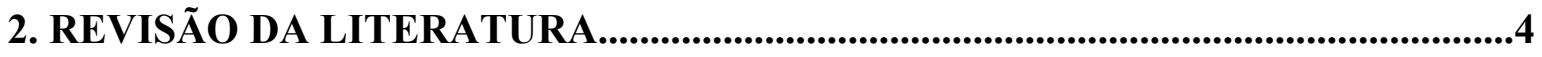



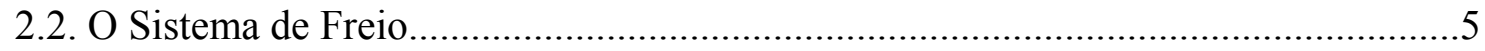

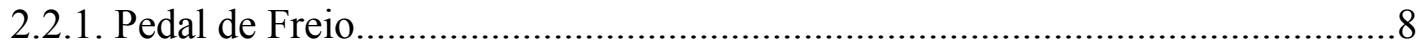

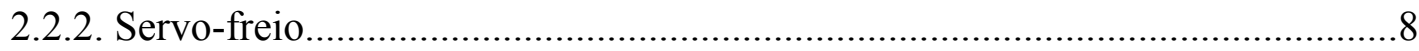

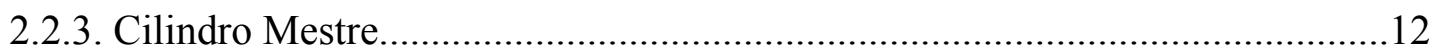

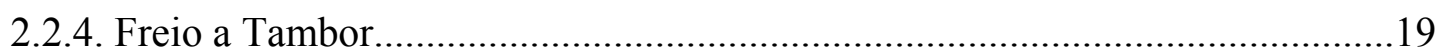

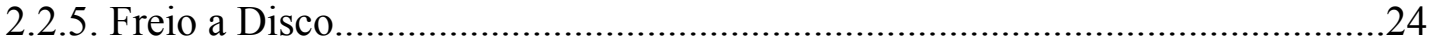

2.2.6. Dispositivos de controle de pressão..............................................................29

2.2.7. Configurações do circuito hidráulico do freio....................................................33

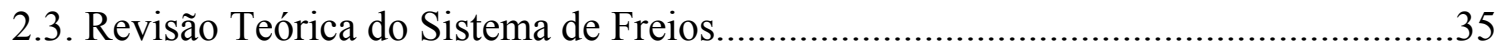

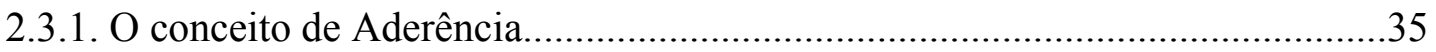

2.3.2. Dinâmica da frenagem...............................................................................4 41

2.3.3. Curva de distribuição de frenagem...............................................................45

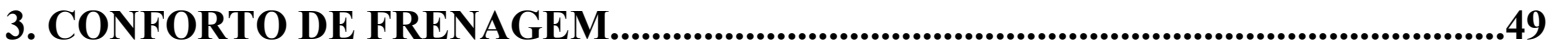

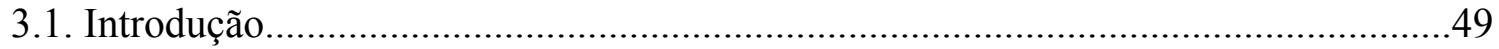

3.2. Análise Objetiva do Conforto de Frenagem..............................................................52



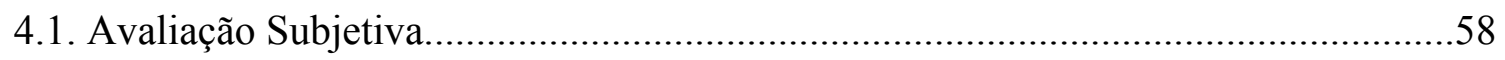

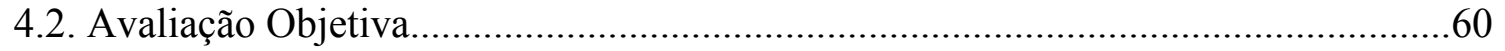


4.3. Modelagem dinâmica da frenagem em linha reta..................................................68

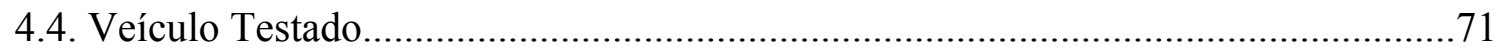

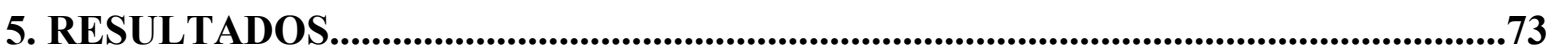



5.2. Resultados da avaliação de absorção dos freios a disco............................................77

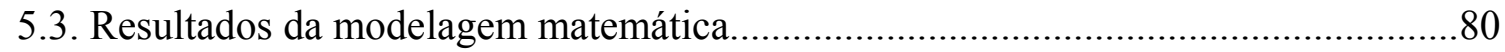

5.3.1. Coeficientes de atrito iguais entre a pastilha original e a pastilha proposta.....81

5.3.2. Coeficientes de atrito diferentes entre a pastilha original e a pastilha

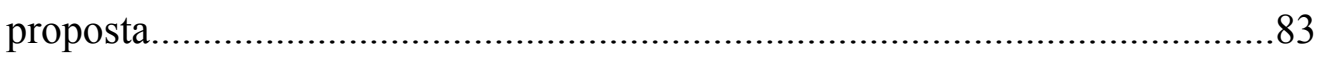

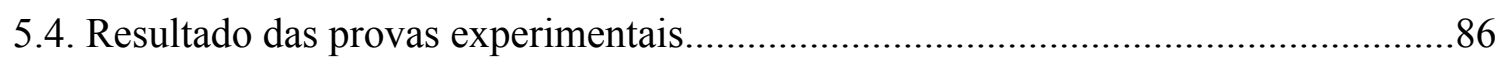

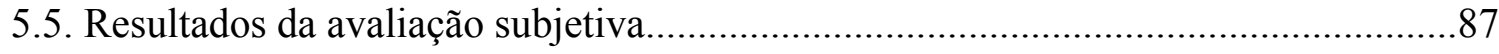

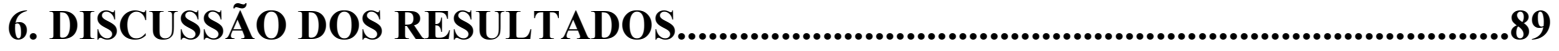

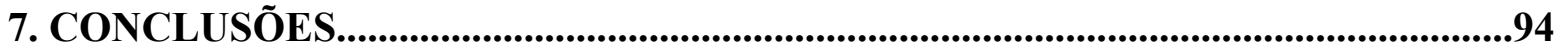

8. REFERÊNCIAS BIBLIOGRÁFICAS...............................................................97

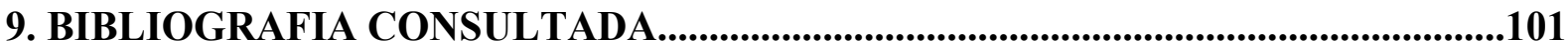




\section{LISTA DE FIGURAS}

Figura 2.1 - Sistema de freio convencional de um automóvel de passeio. .5

Figura 2.2 - Sistema de freio convencional com assistência eletrônica de um automóvel de passeio 6

Figura 2.3 - Sistema de freio eletro-hidráulico (SBC) ....................................................

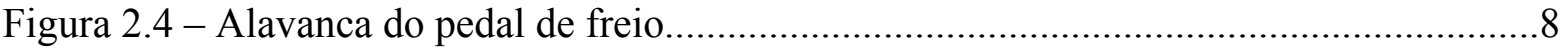

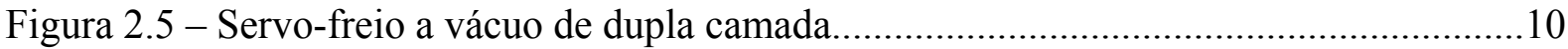

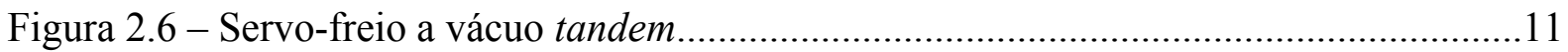

Figura 2.7 - Cilindro mestre convencional em repouso....................................................13

Figura 2.8 - Cilindro mestre convencional durante a aplicação do freio................................14

Figura 2.9 - Cilindro mestre convencional durante a liberação do freio.................................15

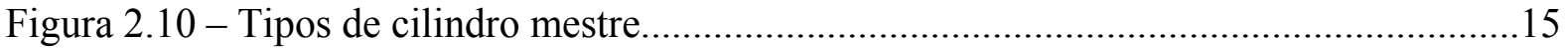

Figura 2.11 - Danos nos lábios da gaxeta de vedação num cilindro mestre convencional

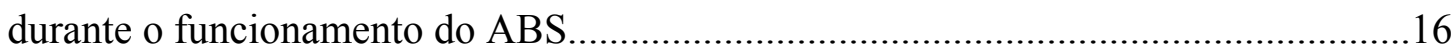

Figura 2.12 - Cilindro mestre com válvula central na posição de repouso.............................16

Figura 2.13 - Cilindro mestre com válvula central durante a aplicação do freio.....................17

Figura 2.14 - Cilindro mestre com válvula central durante a liberação do freio......................18

Figura 2.15 - Reservatório do Cilindro Mestre..................................................................18

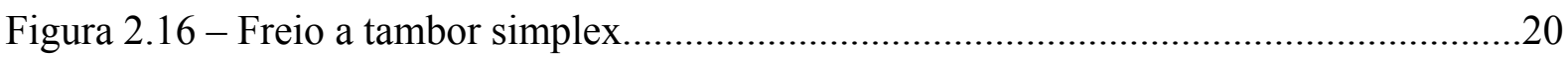

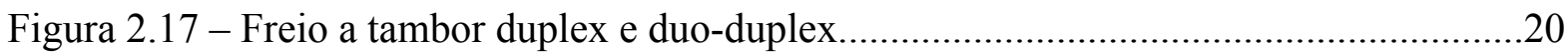

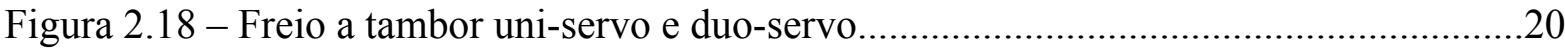

Figura 2.19 - Freio a tambor simplex com mecanismo de freio de estacionamento..............21

Figura 2.20 - Mecanismo de regulagem automática do freio a tambor.................................22

Figura 2.21 - Regulagem automática com compensação térmica..........................................22 
Figura 2.22 - Fatores de freio $C^{*}$ em função do coeficiente de atrito e velocidade de início da frenagem. .23

Figura 2.23 - Tipos de freio a disco: (a) tipo fixo; (b) tipo flutuante.....................................25

Figura 2.24 - Mecanismo de auto-regulagem dos freios a disco.......................................26

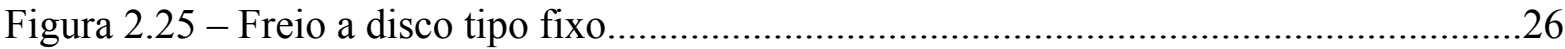

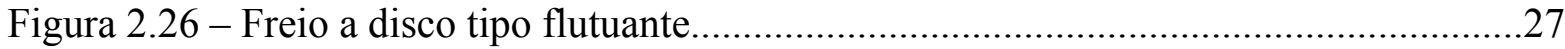

Figura 2.27 - Freio a disco flutuante com mecanismo de freio de estacionamento................28

Figura 2.28 - Efeito da transferência dinâmica de carga.......................................................29

Figura 2.29 - Curva de distribuição de frenagem instalada..................................................30

Figura 2.30 - Comportamento da válvula de corte fixo......................................................

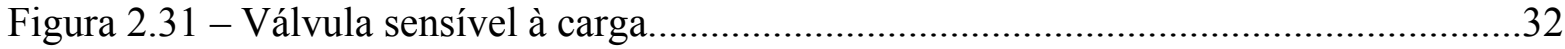

Figura 2.32 - Comportamento da válvula sensível à carga.................................................33

Figura 2.33 - Configurações hidráulicas típicas do sistema de freio.....................................34

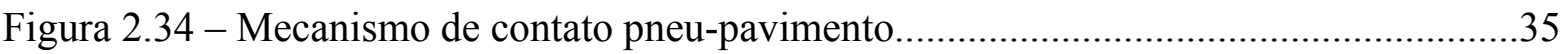



Figura 2.36 - Forças atuantes no pneu durante uma frenagem em curva...............................38

Figura 2.37 - Capacidade de transmissão de força nos sentidos longitudinal e lateral, em função do escorregamento longitudinal (pneu radial 205/60 R15 com 2 bar de pressão, carga dinâmica de 4000N e camber 0)....................................................39

Figura 2.38 - Comportamento de aderência pneu-pavimento...............................................41

Figura 2.39 - Sistema de coordenadas conforme SAE J670e............................................42

Figura 2.40 - Sistema de forças atuantes numa frenagem em pavimento plano....................43

Figura 2.41 - Curva de distribuição de frenagem.............................................................46

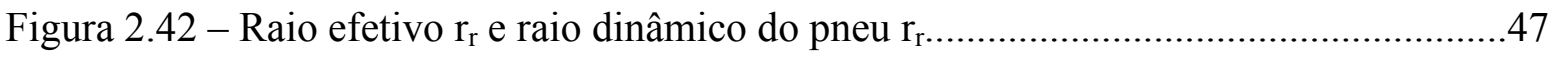

Figura 3.1 - Exemplo de um item de avaliação subjetiva realizada por montadoras............51 
Figura 3.2 - Propriedades de ganho de força de pedal ótima.

Figura 3.3 - Método de Cálculo do Índice de Sensação de Frenagem (BFI)

Figura 4.1 - Dispositivo para medição da absorção volumétrica......

Figura 4.2 - Esquema de um dinamômetro de inércia automotivo.

Figura 4.3 - Dispositivo de medição da compressibilidade da pastilha.

Figura 4.4 - Dinamômetro de inércia para análise de ruído e vibrações.

Figura 4.5 - Esquema de um dinamômetro de chassis.

Figura 4.6 - Fluxograma do programa de simulação matemática para análise objetiva de

conforto de frenagem.

Figura 4.7 - Tela de dados de entrada do programa de cálculo do sistema de freio.

Figura 5.1 - Comparativo da compressibilidade entre a pastilha original e a proposta...........74

Figura 5.2 - NPS máximo por freada para a pastilha original.............................................. 75

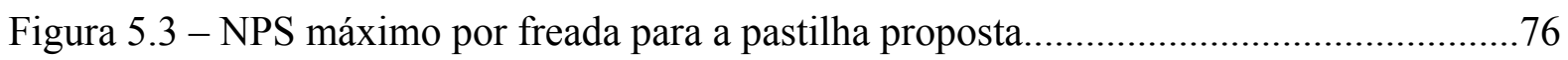

Figura 5.4 - Teste de ruído da pastilha original realizado conforme procedimento interno....77

Figura 5.5 - Teste de ruído da pastilha proposta realizado conforme procedimento interno...77

Figura 5.6 - Absorção volumétrica comparativa (pressão de leitura: 30bar)..........................79

Figura 5.7 - Absorção volumétrica comparativa (pressão de leitura: 70 bar)...........................79

Figura 5.8 - Absorção volumétrica comparativa (pressão de leitura: 100bar).........................80

Figura 5.9 - Força no pedal x desaceleração nas condições de carregamento vazio

(somente com motorista) e carregado (GVM), considerando o mesmo coeficiente de atrito entre as pastilhas original e proposta (Montadora A)

Figura 5.10 - Força no pedal x desaceleração nas condições de carregamento vazio

(somente com motorista) e carregado (GVM), considerando o mesmo coeficiente

de atrito entre as pastilhas original e proposta (Montadora B). 
Figura 5.11 - Curso do pedal x desaceleração nas condições de carregamento vazio (somente com motorista) e carregado (GVM), considerando o mesmo coeficiente de atrito entre as pastilha original e proposta (Montadora B)

Figura 5.12 - Curso do pedal $\mathrm{x}$ força do pedal, considerando o mesmo coeficiente de atrito entre a pastilha original e proposta (Montadora $\mathrm{B}$ ).

Figura 5.13 - Força no pedal x desaceleração nas condições de carregamento vazio (somente com motorista) e carregado (GVM), considerando diferentes coeficientes de atrito entre as pastilhas original e proposta (Montadora A)

Figura 5.14 - Força no pedal x desaceleração nas condições de carregamento vazio (somente com motorista) e carregado (GVM), considerando diferentes coeficientes de atrito entre as pastilhas original e proposta (Montadora B) .84

Figura 5.15 - Curso do pedal x desaceleração nas condições de carregamento vazio (somente com motorista) e carregado (GVM), considerando diferentes coeficientes de atrito entre as pastilha original e proposta (Montadora B).

Figura 5.16 - Curso do pedal x força do pedal, considerando diferentes coeficientes de atrito entre a pastilha original e proposta (Montadora B) .85

Figura 5.17 - Esforço de Pedal x Desaceleração: Medições Experimentais x Modelagem Matemática. 86

Figura 5.18 - Curso de Pedal x Desaceleração: Medições Experimentais x Modelagem Matemática .87 


\section{LISTA DE TABELAS}

Tabela 2.1 - Valores típicos de aderência longitudinal..........................................................40

Tabela 4.1 - Avaliação Subjetiva: Itens relacionados ao conforto de frenagem.....................60

Tabela 4.2 - Definiçãa dos Critérios de Pontuação para o "Screening Test"............................60

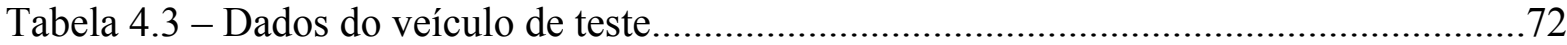

Tabela 5.1 - Coeficientes de atrito obtidos conforme AK-Master Dynamometer

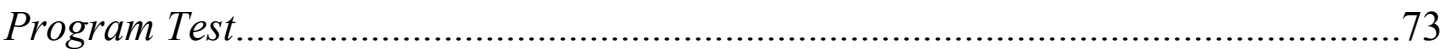



Tabela 5.3 - Dados de pressão de acomodação......................................................................78

Tabela 5.4 - Absorção volumétrica comparativa em função da pressão aplicada (condição de teste: pressão de medição 30 bar)..............................................................78

Tabela 5.5 - Absorção volumétrica para a pressão de leitura de 30 bar...................................80

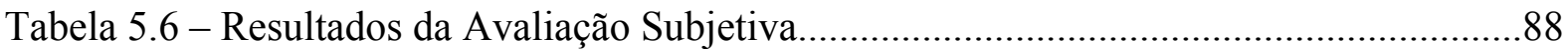

Tabela 6.1 - Força de pedal x desaceleração (faixa de 0 a $3,0 \mathrm{~m} / \mathrm{s}^{2}$ )..................................90

Tabela 6.2 - Curso no pedal x desaceleração (faixa de 0 a $3,0 \mathrm{~m} / \mathrm{s}^{2}$ )................................90

Tabela 6.3 - Força de pedal x desaceleração (faixa de 0 a $3,0 \mathrm{~m} / \mathrm{s}^{2}$ )...................................90

Tabela 6.4 - Curso no pedal x desaceleração (faixa de 0 a $3,0 \mathrm{~m} / \mathrm{s}^{2}$ )..................................91 


\section{LISTA DE ABREVIATURAS E SIGLAS}

ABS Anti-lock Braking System

ABNT Associação Brasileira de Normas Técnicas

BA Brake Assistant

BBW Brake-by-Wire

CG Centro de Gravidade

DIN Deutsches Institut für Normung

EBD Electronic Braking Distribution

ECE Economic Commission for Europe

EMB Electromechanical Brake

ESP Electronic Stability Program

FMVSS Federal Motor Vehicle Safety Standard

HDC Hill Descent Control

NHTSA National Highway Traffic Safety Administration

NPS Nível de Pressão Sonora

SAE Society of Automotive Engineers

SBC Sensotronic Brake Control

TCS Traction Control System 


\section{LISTA DE SÍMBOLOS}

\begin{tabular}{|c|c|}
\hline $\mathrm{A}_{\mathrm{MC}}$ & área do êmbolo do cilindro mestre $\left[\mathrm{mm}^{2}\right]$ \\
\hline $\mathrm{A}_{\mathrm{WC}}$ & $\begin{array}{l}\text { área do êmbolo do cilindro de roda ou do êmbolo do freio a disco } \\
{\left[\mathrm{mm}^{2}\right]}\end{array}$ \\
\hline $\mathrm{b}$ & desaceleração $\left[\mathrm{m} / \mathrm{s}^{2}\right]$ \\
\hline $\mathrm{BF}$ ou $\mathrm{C}^{*}$ & fator de freio [adimensional] \\
\hline $\mathrm{BF}_{\mathrm{f}}$ & fator do freio dianteiro [adimensional] \\
\hline $\mathrm{BF}_{\mathrm{t}}$ & fator do freio traseiro [adimensional] \\
\hline $\mathrm{F}_{1}$ & soma das forças de resistência impostas pelo solo à roda dianteira $[\mathrm{N}]$ \\
\hline $\mathrm{F}_{2}$ & soma das forças de resistência impostas pelo solo à roda traseira [N] \\
\hline $\mathrm{F}_{\mathrm{f}}$ & força de frenagem imposta pelo freio dianteiro $[\mathrm{N}]$ \\
\hline $\mathrm{F}_{\mathrm{P}}$ & força no pedal de freio $[\mathrm{N}]$ \\
\hline $\mathrm{F}_{S}$ & força lateral $[\mathrm{N}]$ \\
\hline $\mathrm{F}_{\mathrm{t}}$ & força de frenagem imposta pelo freio traseiro $[\mathrm{N}]$ \\
\hline $\mathrm{F}_{\mathrm{Xi}}$ & força de frenagem máxima atuante no pneu [N] \\
\hline $\mathrm{g}$ & aceleração da gravidade $\left[\mathrm{m} / \mathrm{s}^{2}\right]$ \\
\hline $\mathrm{H}$ & altura do CG em relação ao solo [mm] \\
\hline $\mathrm{i}$ & designação do eixo [adimensional] \\
\hline $1_{\mathrm{o}}$ & curso morto $[\mathrm{mm}]$ \\
\hline $1_{\mathrm{p}}$ & Relação do pedal de freio [adimensional] \\
\hline $\mathrm{L}$ & distância entre eixos [mm] \\
\hline $\mathrm{L}_{\mathrm{f}}$ & distância do CG ao eixo dianteiro [mm] \\
\hline $\mathrm{L}_{\mathrm{t}}$ & distância do CG ao eixo traseiro [mm] \\
\hline $\mathrm{m}$ & massa total do veículo $[\mathrm{kg}]$ \\
\hline $\mathrm{p}_{\mathrm{o}}$ & pressão pré-operativa, necessária para que as sapatas ou pastilhas \\
\hline & entrem em contato com o tambor ou disco [bar] \\
\hline $\mathrm{p}_{1}$ & pressão hidráulica de fluido que alimenta os freios de roda [bar] \\
\hline $\mathrm{R}_{\mathrm{D}}$ ou $\mathrm{r}_{\mathrm{r}}$ & raio dinâmico do pneu $[\mathrm{mm}]$ \\
\hline$r_{e f}$ ou $r_{f}$ & raio efetivo do disco de freio $[\mathrm{mm}]$ \\
\hline$r_{\text {et }}$ & raio efetivo do tambor de freio $[\mathrm{mm}]$ \\
\hline $\mathrm{S}_{\mathrm{p}}$ & curso do pedal de freio $[\mathrm{mm}]$ \\
\hline $\mathrm{v}_{\mathrm{F}}$ & velocidade linear longitudinal da roda $[\mathrm{m} / \mathrm{s}]$ \\
\hline
\end{tabular}




$\begin{array}{ll}\mathrm{V}_{\mathrm{U}} & \text { velocidade tangencial do pneu [m/s] } \\ \mathrm{V}_{\mathrm{i}} & \text { perda de volume de cada componente de freio }\left[\mathrm{cm}^{3}\right] \\ \mathrm{W} & \text { força peso [N] } \\ \mathrm{W}_{\mathrm{b}} \text { ou } \mathrm{W}_{\mathrm{bi}} & \text { peso dinâmico sobre o eixo [N] } \\ \mathrm{W}_{\mathrm{bf}} & \text { peso dinâmico sobre o eixo dianteiro [N] } \\ \mathrm{W}_{\mathrm{bt}} & \text { peso dinâmico sobre o eixo traseiro [N] } \\ \mathrm{W}_{\mathrm{f}} & \text { peso estático sobre o eixo dianteiro [N] } \\ \mathrm{W}_{\mathrm{t}} & \text { peso estático sobre o eixo traseiro [N] } \\ \eta_{\mathrm{Cf}} & \text { eficiência do freio a disco [adimensional] } \\ \eta_{\mathrm{Ct}} & \text { eficiência do freio a tambor [adimensional] } \\ \eta_{\mathrm{p}} & \text { eficiência do pedal do freio [adimensional] } \\ \lambda & \text { escorregamento [adimensional] } \\ \mu_{\mathrm{f}} & \text { aderência longitudinal do eixo dianteiro [adimensional] } \\ \mu_{\mathrm{L}} \text { ou } \mu_{\mathrm{HF}} & \text { aderência longitudinal [adimensional] } \\ \mu_{\mathrm{s}} & \text { aderência na direção lateral [adimensional] } \\ \mu_{\mathrm{sf}} & \text { aderência na direção lateral, eixo dianteiro [adimensional] } \\ \mu_{\mathrm{st}} & \text { aderência na direção lateral, eixo traseiro [adimensional] } \\ \mu_{\mathrm{t}} & \text { aderência longitudinal do eixo traseiro [adimensional] } \\ \omega & \text { velocidade angular da roda [rad/s] }\end{array}$




\section{RESUMO}

Considerando o nível de competitividade do mercado automobilístico atual, a satisfação do cliente tem se tornado uma vantagem competitiva a ser considerada, devido ao aumento da expectativa dos clientes em relação à percepção da qualidade. Neste aspecto, uma das maiores dificuldades existentes no projeto de sistemas de freio reside no fato de transformar informações e/ou opiniões subjetivas em informações e/ou dados objetivos, tais como parâmetros de projeto.

O presente trabalho investiga a análise objetiva do conforto de frenagem de automóveis de passeio, estabelecendo indicadores que auxiliem e/ou complementem as análises subjetivas normalmente utilizadas pela empresa, para um estudo de caso envolvendo a mudança de material de atrito da pastilha do freio a disco de um automóvel de passeio.

Foram utilizados para a análise objetiva, programas de simulação computacional para analisar o desempenho do sistema de freio com relação aos indicadores estabelecidos. Os dados obtidos através desta simulação foram comparados, tanto com os resultados da avaliação subjetiva, quanto aos resultados de medições experimentais do veículo analisado, buscando analisar a correlação dos resultados.

Ao final do trabalho, da comparação realizada entre a avaliação subjetiva e a avaliação objetiva observou-se uma melhoria no conforto de frenagem aos usuários, apesar de ser imperceptível na avaliação subjetiva. Esta ferramenta será muito importante no estabelecimento da curva de conforto de frenagem ótima para os novos desenvolvimentos de sistemas de freio eletrohidráulicos, denominados "brake-by-wire" (BBW). 


\begin{abstract}
Considering today's competitive automotive market, the customer satisfaction has become a competitive advantage to be considered, due to the customer expectation increasing regarding the quality perception. In this aspect, one of biggest existing difficulties in the brake system design is to transform subjective information and/or opinions into objective information and/or data, such as design parameters.

The present study investigates the objective analysis of the brake pedal feeling for passenger cars, establishing index that can support and/or complement the subjective analysis, usually used by our company, for a study case involving the friction material change of passenger car's caliper brake pad.

The computational simulation program has been used for the objective analysis, to analyze the brake system performance based on established index. The obtained data through this simulation was compared with the subjective evaluation results as much as with experimental measurements results of the analyzed vehicle, analyzing the correlation of results.

To the end of this study, based on the comparison between subjective evaluation and objective evaluation, it observed a brake comfort improvement for drivers, instead of this characteristic would be imperceptive in subjective evaluation. This tool will be very important in the optimum comfort curve establishment for the new developments of electro-hydraulic brake systems, called "brake-by-wire" (BBW).
\end{abstract}




\section{INTRODUÇÃO}

Historicamente, os projetos de sistemas de freio de automóveis de passeio sempre levaram em conta como objetivo principal, o atendimento das normas regulamentadoras, que são estabelecidas por órgãos governamentais que regulamentam o trânsito de veículos em seus países. Como principais exemplos destas normas, temos a regulamentação Federal Motor Vehicle Safety Standard (FMVSS) 135, estabelecida pela National Highway Traffic Safety Administration (NHTSA) dos Estados Unidos da América e a regulamentação Economic Commision for Europe (ECE) 13 e $13 \mathrm{H}$ estabelecida pela Comunidade Econômica Européia. Similarmente no Brasil, o Conselho Nacional de Trânsito (CONTRAN) também estabelece a sua regulamentação para sistemas de freio - o CONTRAN 777/93 e as Normas Técnicas NBR-10966 (Norma NB-1253), NBR-10967 (Método MB3160), NBR-10968 (Método MB-3161), NBR-10969 (Norma NB-1254) e NBR-10970 (Norma NB-1255) da Associação Brasileira de Normas Técnicas (ABNT), que são baseadas em parte na regulamentação européia ECE-13/05.

Tais regulamentações estabelecem basicamente os requisitos mínimos os quais os veículos devem atender para que possam trafegar oferecendo o nível mínimo de segurança não só para o motorista e passageiros, como também para as pessoas e veículos que circulam ao redor do mesmo. Dentro destes requisitos, são estabelecidos limites para esforços máximos para acionamento do pedal de freio e da alavanca de freio de estacionamento, desacelerações mínimas e/ou distâncias de parada máximas sobre certas condições de frenagem, sejam elas em condições normais de funcionamento ou simulando condições de falha no sistema de freio. Contudo, o atendimento dessas regulamentações não indica, necessariamente, que os automóveis apresentem uma boa sensação no uso de pedal de freio no momento da frenagem do veículo, uma vez que, todos os automóveis em circulação apesar de atenderem tais 
regulamentações, oferecem sensações de conforto muito diferentes aos motoristas, durante o acionamento do pedal de freio.

Considerando o nível de competitividade do mercado automobilístico atual, a satisfação do cliente tem se tornado uma vantagem competitiva a ser considerada, devido ao aumento da expectativa dos clientes em relação à percepção da qualidade. $\mathrm{O}$ atendimento destas expectativas pode resultar em sucesso ou fracasso nas vendas dos veículos lançados no mercado. Portanto, as sensações de conforto de frenagem exercem sua relevância em relação à percepção da qualidade, pelo fato de ser um dos primeiros pontos de contatos com que o motorista/cliente tem com o veículo em movimento.

Desta forma, uma das maiores dificuldades existentes no projeto de sistemas de freio reside no fato de transformar opiniões, informações e/ou expectativas dos motoristas/clientes, que normalmente são subjetivas, em parâmetros ou dados de projeto, que normalmente são numéricos, ou seja, objetivos. Mesmo as análises de conforto de frenagem realizadas tanto por parte da indústria automotiva quanto por parte da imprensa especializada se baseiam em critérios subjetivos, de modo que os seus resultados dependem pura e exclusivamente da sensibilidade do avaliador em transformar as sensações em dados realmente úteis ao engenheiro projetista.

Este trabalho tem por objetivo estudar os critérios relativos ao conforto do usuário em projetos de sistemas de freio de automóveis de passeio de modo a propor métodos quantitativos, através de indicadores que auxiliem e/ou complementem as análises subjetivas que são atualmente utilizadas nos projetos de sistemas de freio, de tal maneira que esta avaliação se torne independente do "gosto" dos avaliadores. A utilização de métodos quantitativos permitirá que sejam realizadas análises numéricas de desempenho do sistema de freio, possibilitando avaliar o comportamento do sistema de freio de um veículo, seja ele existente ou totalmente novo. 
Com relação à estrutura desta dissertação, o capítulo 2 se inicia com uma revisão da literatura, apresentando os conceitos básicos sobre os sistemas de freios de um automóvel de passeio, a descrição de seus componentes e suas funções dentro do sistema. É apresentada também a caracterização dos diferentes tipos de componentes, que normalmente são encontrados nos veículos.

Ainda no capítulo 2, será apresentada a modelagem matemática básica para cálculo do sistema de freio de um veículo, considerando as forças de frenagem atuantes em um veículo trafegando em linha reta.

No capítulo 3 são tratados os métodos descritos por diversos autores sobre a análise de conforto de frenagem, estabelecendo a ligação entre os dados subjetivos obtidos por clientes/motoristas, sejam eles consumidores ou técnicos especialistas, e os parâmetros objetivos a serem definidos que representassem a opinião do cliente.

O capítulo 4 descreve o procedimento adotado na análise subjetiva e objetiva do conforto de frenagem para o estudo de caso proposto, a modelagem escolhida, mencionando o programa computacional utilizado, os cálculos realizados e a característica do veículo selecionado para análise.

O capítulo 5 revela os resultados obtidos através da análise subjetiva e objetiva do conforto de frenagem, através da aplicação do programa computacional para o estudo de caso. Além disso, também se apresentam resultados de medição experimental no veículo para serem comparados com os resultados obtidos na simulação matemática.

No capítulo 6, desenvolve-se uma discussão sobre os resultados das avaliações objetivas, a serem obtidas nas simulações realizadas ou constatadas experimentalmente, e comparadas com os resultados obtidos na avaliação subjetiva.

No capítulo 7, apresentam-se as principais conclusões do trabalho e também são incluídas sugestões de temas para pesquisas futuras. 


\section{REVISÃO DA LITERATURA}

\subsection{Conceitos Básicos}

O sistema de freio é parte fundamental de um veículo, pois permite seu uso adequado e seguro em condições de tráfego nas ruas e estradas. Devido a sua importância na segurança do veículo, requisitos legais que regulamentam o seu funcionamento e o seu desempenho são estabelecidos por vários órgãos reguladores do tráfego de automóveis em vários países.

Em linhas gerais, um sistema de freio de um veículo automotor, deve cumprir as seguintes tarefas fundamentais (LIMPERT, 1999; BAUER, 2003):

- Reduzir a velocidade do veículo em movimento, aumentando a taxa de desaceleração do mesmo;

- Parar o veículo completamente;

- Manter a velocidade do veículo, impedindo a aceleração não desejada durante o seu trajeto em um declive;

- Manter o veículo estacionado quando este está completamente parado.

Estas tarefas fundamentais devem ser desempenhadas em sua totalidade em condições normais de uso, e com um menor grau de eficiência durante uma falha do sistema. Conseqüentemente, os freios podem ser classificados como (LIMPERT, 1999):

- Freios de serviço, responsável pela execução das três primeiras tarefas em sua totalidade;

- Freios secundários ou de emergência, que executam as três primeiras tarefas, mas com um menor grau de eficiência durante a falha parcial do sistema; e

- Freio de estacionamento, que é responsável pela execução da última tarefa fundamental. 


\subsection{O Sistema de Freio}

Nos modernos automóveis de passeio, os sistemas de freio podem ser classificados em convencionais e eletrônicos (BAUER, 2003).

Os sistemas de freio convencionais são comumente aplicados em quase toda a totalidade dos automóveis de passeio, devido ao seu custo menor frente aos eletrônicos. A seqüência de frenagem é iniciada pela aplicação de uma força mecânica no pedal de freio que é transformada em pressão hidráulica pelo conjunto servo-freio / cilindro mestre, que por conseqüência, aciona os freios de roda.

A figura 2.1 apresenta um típico sistema de freio convencional de acionamento mecânico-hidráulico, utilizado em automóveis de passeio.

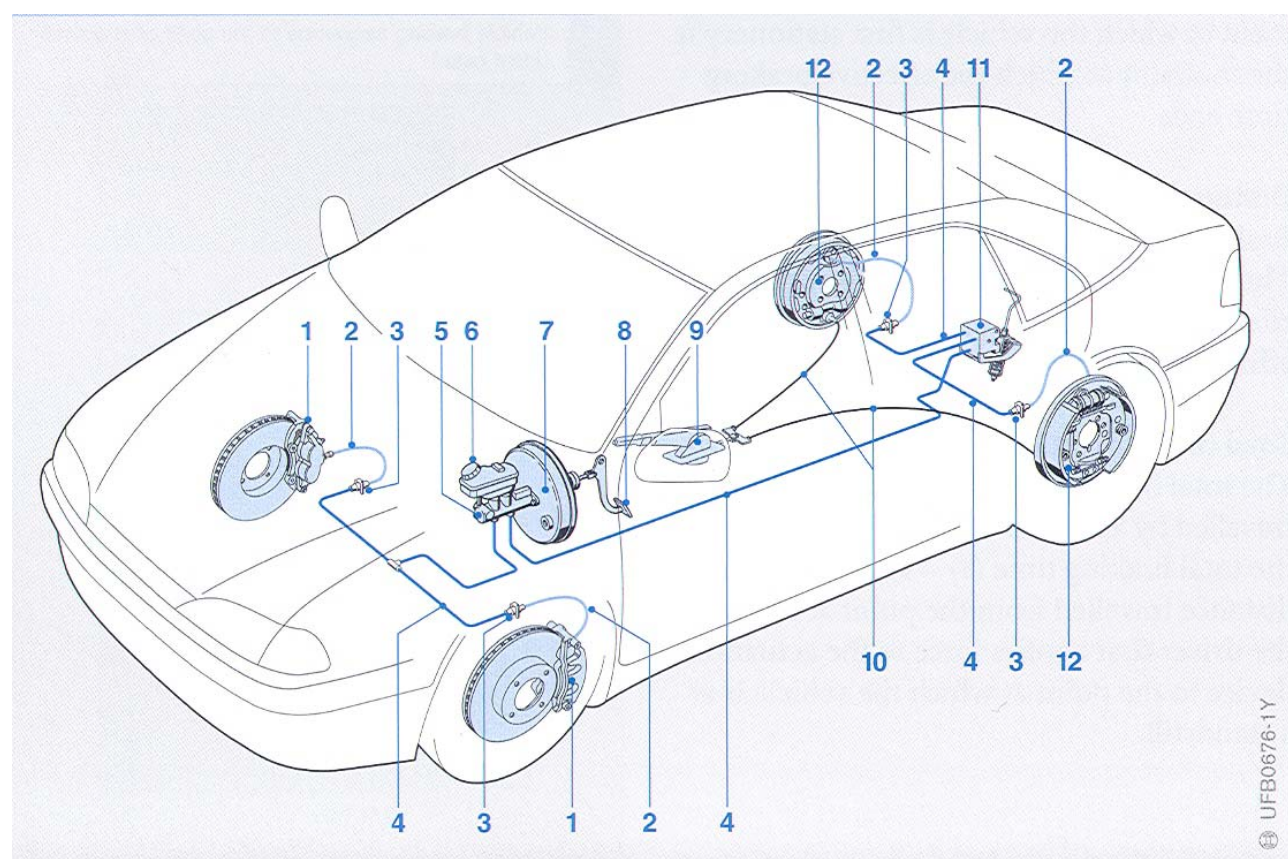

(1) freio a disco dianteiro; (2) flexível de freio; (3) conexão hidráulica; (4) tubo de freio;

(5) cilindro mestre; (6) reservatório; (7) servo-freio; (8) pedal de acionamento do freio;

(9) alavanca do freio de estacionamento; (10) cabo do freio de estacionamento;

(11) válvula reguladora sensível à carga; (12) freio a tambor traseiro.

Figura 2.1 - Sistema de freio convencional de um automóvel de passeio (BAUER, 2003). 
Neste sistema, a intensidade da frenagem e a sua duração são determinadas pela ação do motorista.

Os sistemas de freio eletrônicos buscam desempenhar basicamente duas funções:

- Complementação das funções de segurança ao motorista, quando aplicado em conjunto com os freios convencionais. Nesta classe, encontram-se os sistemas Anti-lock Brake Systems (ABS), Electronic Stability Program (ESP), Brake Assistant (BA), Electronic Brake Distribution (EBD) e Hill Descent Control (HDC). A figura 2.2 apresenta um típico sistema de freio convencional com assistência eletrônica;

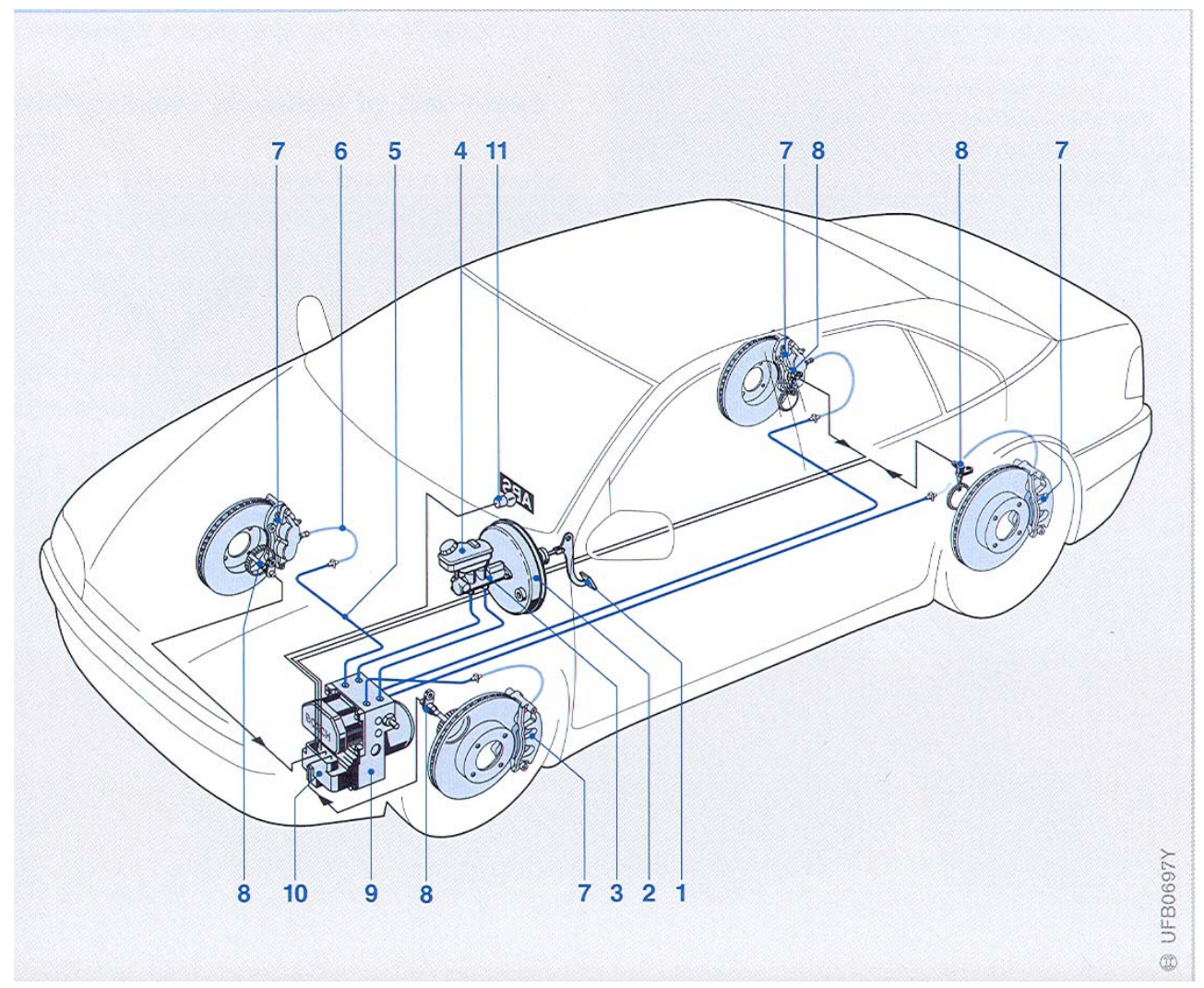

(1) pedal de acionamento do freio; (2) servo-freio; (3) cilindro mestre; (4) reservatório;

(5) tubo de freio; (6) flexível de freio; (7) freio a disco dianteiro; (8) sensor de velocidade;

(9) modulador hidráulico; (10) unidade de controle do ABS;

(11) lâmpada de advertência de falha do ABS

Figura 2.2 - Sistema de freio convencional com assistência eletrônica de um automóvel de passeio (BAUER, 2003). 
- Realização da conexão entre pedal de freio e freios de roda através de sinais elétricos, eliminando parcial ou totalmente a transmissão de pressão hidráulica. Nesta classe, encontramos os Brake-by-Wire (BBW), representado pelos Sensotronic Brake Control (SBC) e Electromechanical Brake (EMB). A figura 2.3 apresenta um sistema de freio eletrônico, do tipo eletro-hidráulico (SBC).

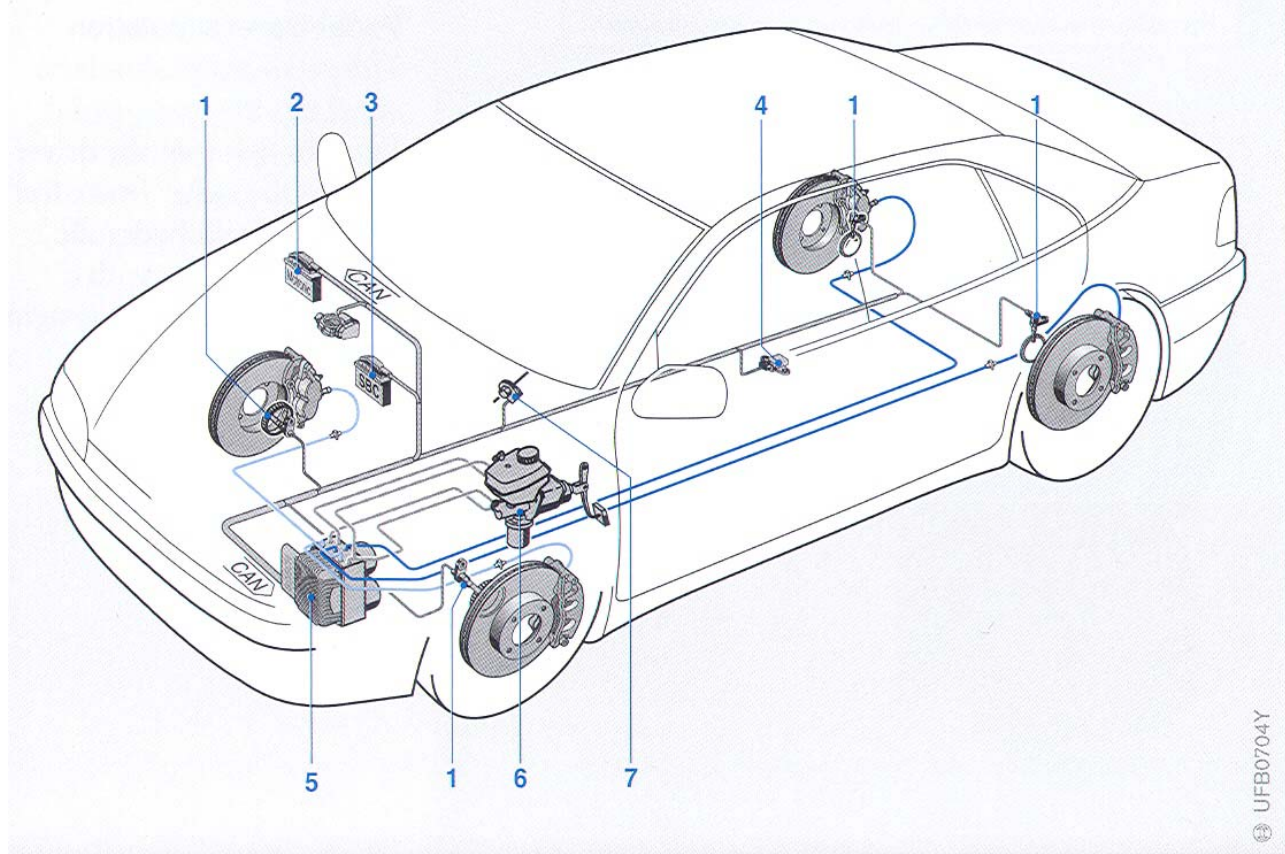

(1) sensor de velocidade ativo com sensor de direção; (2) unidade de gerenciamento do motor;

(3) unidade de gerenciamento do SBC; (4) sensor aceleração lateral e guinada;

(5) modulador hidráulico; (6) unidade de atuação com sensor de curso de pedal;

(7) sensor de ângulo de esterçamento.

Figura 2.3 - Sistema de freio eletro-hidráulico (SBC) (BAUER, 2003).

Os principais componentes do sistema de freio convencional são descritos a seguir: 


\subsubsection{Pedal de Freio}

O pedal de freio, conforme a figura 2.4, é uma alavanca que normalmente fica suspensa e se encontra localizado ao lado esquerdo do pedal do acelerador. Sua função é transmitir a força de acionamento do motorista ao sistema de freio, trabalhando como uma alavanca multiplicadora de força, que aciona o sistema de atuação do freio, composto pelo conjunto servo-freio e cilindro mestre. Estes por sua vez, convertem a força mecânica de entrada em pressão hidráulica para os freios de roda (BAUER, 2003).

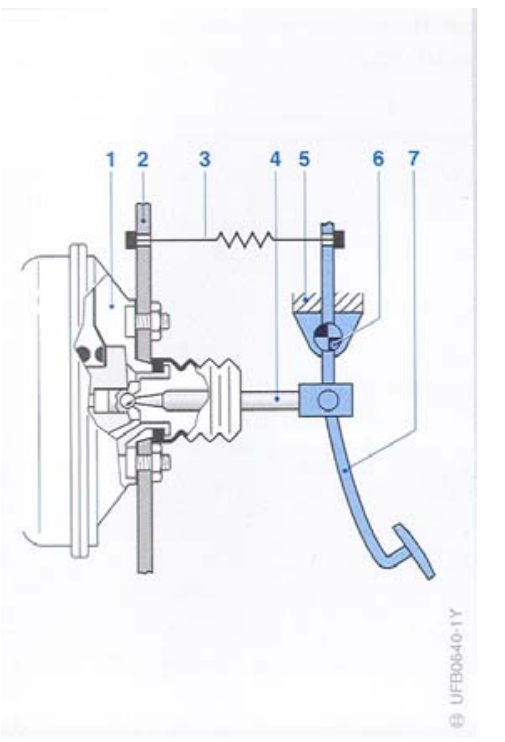

(1) servo-freio; (2) painel do compartimento do motor; (3) mola de retorno;

(4) haste de acionamento; (5) fixação; (6) pino de articulação; (7) pedal.

Figura 2.4 - Alavanca do pedal de freio (BAUER, 2003).

A ação multiplicadora da força de pedal de freio é determinada pela relação do pedal de freio, que influencia em parte a sensação no pedal de freio que o motorista sente.

\subsubsection{Servo-freio}

O servo-freio é um dispositivo auxiliar que amplifica a força aplicada pelo motorista durante a frenagem do veículo, com objetivo de aumentar o poder e a eficácia da frenagem, ao mesmo tempo em que melhora o seu conforto. Normalmente é fornecido em conjunto com o cilindro mestre, formando uma única unidade, denominada de atuação, 
facilitando não só o seu manuseio durante a sua montagem na linha de produção da montadora, como garante a integridade e o perfeito funcionamento tanto do servo-freio quanto do cilindro mestre (BAUER, 2003).

Podemos encontrar os seguintes tipos de servo-freio: servos-freios com assistência a vácuo e servos-freios com assistência hidráulica.

O tipo de servo-freio mais comumente encontrado nos automóveis de passeio é aquele cuja assistência é dada pelo vácuo, que é gerada no coletor de admissão nos veículos com motor ciclo Otto, movidos à gasolina e/ou a álcool. O nível de vácuo gerado no coletor de admissão, com a válvula borboleta fechada, pode chegar a aproximadamente 0,8 bar (BOSCH, 2004). Para motores com nível baixo de vácuo, como os motores ciclo Diesel, normalmente são utilizadas bombas de vácuo. Para suprir a necessidade dos servos-freios, as bombas de vácuo são instaladas junto aos motores de forma independente ou ligadas a outros componentes, tais como alternadores ou bombas da direção hidráulica (BOSCH, 2004).

Existem duas versões de servos-freios a vácuo, ambas com funcionamento similar, a saber:

- $\quad$ Servo-freio de dupla câmara (figura 2.5);

- Servo-freio tandem, ou de quatro câmaras (figura 2.6); 


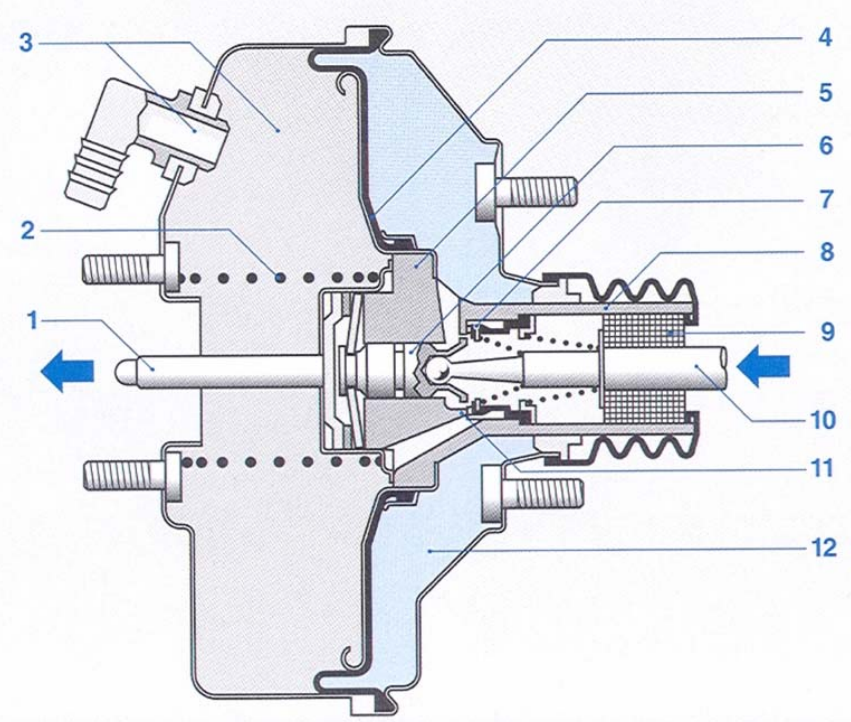

(1) haste do cilindro mestre; (2) mola; (3) câmara de vácuo e válvula de retenção;

(4) diafragma e disco do diafragma; (5) pistão de acionamento; (6) êmbolo sensor;

(7) válvula dupla; (8) corpo de válvula; (9) filtro de ar; (10) haste de conexão;

(11) assento da válvula; (12) câmara de trabalho.

Figura 2.5 - Servo-freio a vácuo de dupla câmara (BAUER, 2003).

No funcionamento do servo-freio de dupla câmara, o diafragma que é produzido em elastômero SBR (Item 4, figura 2.5), encontra-se fixada ao disco do diafragma, separando duas câmaras, a de vácuo (Item 3, figura 2.5) e a de trabalho (Item 12, figura 2.5). Quando o freio não é aplicado, as duas câmaras encontram-se interligadas através de cavidades no interior do corpo de válvula (Item 8 , figura 2.5 ), de modo que haja vácuo em ambas as câmaras. Ao iniciar o acionamento do pedal de freio, a haste de conexão (Item 10, figura 2.5) movimenta o êmbolo sensor (Item 6, figura 2.5), permitindo a passagem de ar atmosférico pelos filtros (Item 9, figura 2.5) à câmara de trabalho. Ao mesmo tempo, a ação das molas em conjunto com a haste de conexão movimenta a válvula dupla (Item 7, figura 2.5), de modo que a câmara de vácuo não seja atingida pelo ar atmosférico.

A diferença de pressão entre as duas câmaras (vácuo na câmara de vácuo e pressão atmosférica na câmara de trabalho) gera uma força resultante que é aplicada ao diafragma sobre o disco do diafragma, que por sua vez, estando ligado ao pistão de 
acionamento (Item 5, figura 2.5), movimenta-o, auxiliando a força de pedal transmitida pela haste de conexão.

Ao liberar o pedal de freio, o servo-freio volta a sua condição original, interligando as duas câmaras para uma próxima frenagem.



(1) haste do cilindro mestre; (2) mola; (3) câmara de vácuo II e válvula de retenção;

(4) diafragma II e disco do diafragma II; (5) câmara de vácuo I; (6) divisão;

(7) diafragma I; (8) cilindro de acionamento; (9) êmbolo sensor; (10) válvula dupla;

(11) corpo de válvula; (12) filtro de ar; (13) haste de conexão; (14) assento da válvula;

(15) câmara de trabalho I; (16) câmara de trabalho II.

Figura 2.6 - Servo-freio a vácuo tandem (BAUER, 2003).

No servo-freio tandem ou de quatro câmaras a vácuo, o seu funcionamento é similar ao servo-freio de dupla câmara, sendo que neste caso possui duas câmaras de vácuo (Itens 3 e 5, figura 2.6) e duas câmaras de trabalho (Itens 15 e 16, figura 2.6). Quando os freios não estão aplicados há vácuo nas quatro câmaras do servo-freio. Contudo uma vez acionado o êmbolo sensor (Item 9, figura 2.6), esta libera a passagem de ar para as duas câmaras de trabalho, enquanto a válvula dupla (Item 10, figura 2.6) fecha a passagem das câmaras de vácuo à pressão atmosférica. 
Os servos-freios tandem podem ser compostos de câmaras com diafragmas de diâmetros iguais ou diferentes, sendo que no caso de diâmetros diferentes, o maior diâmetro sempre está do lado de fixação do servo-freio na carroceria. O uso dos servos-freios tandem proporciona uma capacidade de auxílio muito maior que os de dupla câmara, contudo, apresentam custos mais elevados que os de dupla câmara e, normalmente apresentam respostas mais lentas, influenciando o conforto de frenagem.

A forma construtiva utilizada nos servos-freios permite que, mesmo que haja danos no diafragma ou problemas na geração de vácuo, não permite que seja afetado o funcionamento do sistema de freio, apesar da perda da assistência originária do auxílio do vácuo.

Nos servos-freios hidráulicos, a assistência é obtida através de uma bomba hidráulica de alta pressão acionada pelo motor do veículo e oferece o mesmo nível de assistência que é fornecida pelos servos-freios a vácuo ao motorista. Geralmente, esses servos-freios são conectados ao sistema da direção hidráulica, compartilhando a mesma bomba. Comparado aos servos-freios a vácuo, apresentam custos maiores de manufatura e são mais pesados, tornando sua aplicação aconselhável somente aos casos onde haja restrição na instalação de um servo-freio a vácuo.

\subsubsection{Cilindro Mestre}

O cilindro mestre realiza a conversão da força exercida pelo motorista no pedal, devidamente amplificada pelo servo-freio, na pressão hidráulica que é aplicada no circuito de freio, de forma proporcional à força do pedal, para acionamento dos freios das rodas. A figura 2.7 mostra um cilindro mestre convencional comumente utilizado em automóveis de passeio sem sistema ABS (LUCAS, 1995a). 


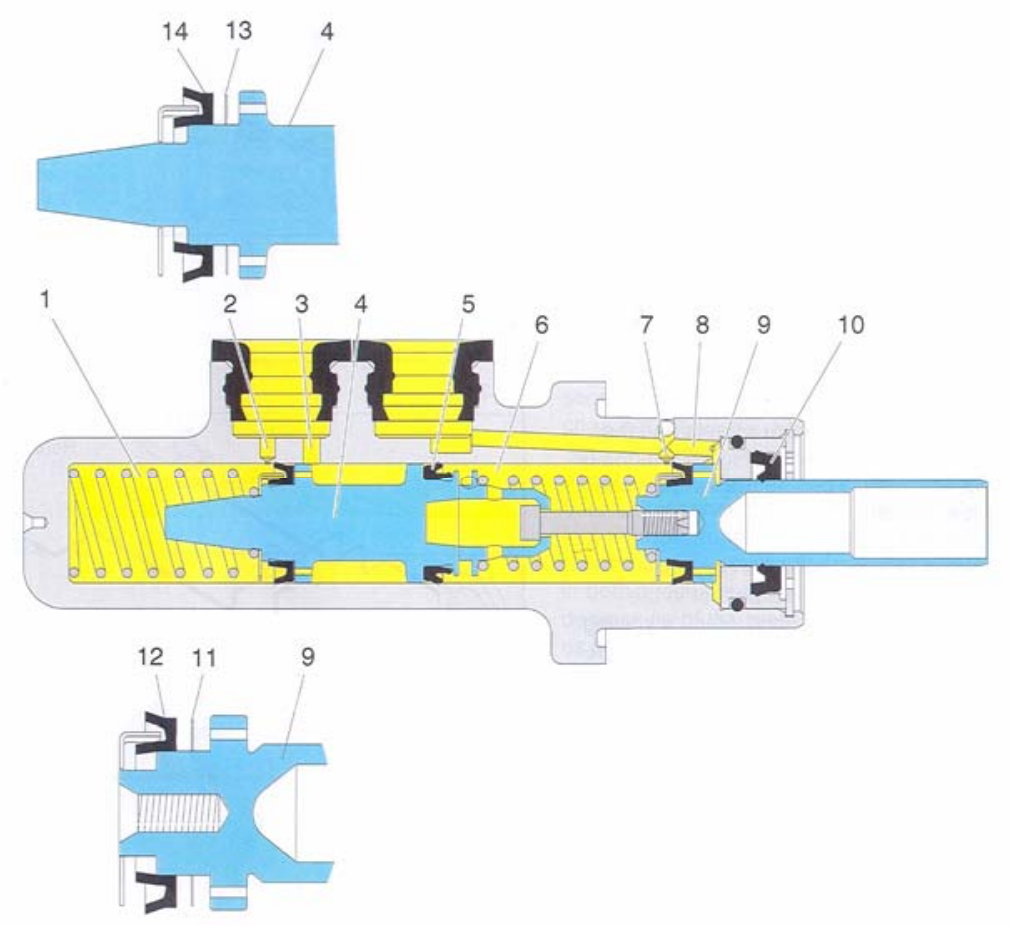

(1) circuito secundário; (2) furo de compensação, circuito secundário; (3) furo de alimentação, circuito secundário; (4) êmbolo secundário; (5) gaxeta de isolamento; (6) circuito primário; (7) furo de compensação, circuito primário; (8) furo de alimentação, circuito primário; (9) êmbolo primário; (10) vedação traseira; (11) espaçador, êmbolo primário; (12) gaxeta de recuperação; (13) espaçador, êmbolo secundário; (14) gaxeta de recuperação, êmbolo secundário.

Figura 2.7 - Cilindro mestre convencional em repouso (LUCAS, 1995a).

As figuras 2.7, 2.8 e 2.9 mostram respectivamente as condições do cilindro mestre convencional em repouso (sem aplicação da força do pedal), durante a aplicação e na liberação do freio.

$\mathrm{Na}$ condição de repouso, ambos os furos de compensação (Item 2 e 7, figura 2.7) de ambos os êmbolos estão abertos e não há pressão no sistema de freio. Quando o pedal de freio é acionado, o movimento é transmitido ao êmbolo primário através da haste do cilindro mestre (Item 3, figura 2.8). No momento em que a gaxeta de recuperação (Item 4, figura 2.8) ultrapassar o furo de compensação (Item 1, figura 2.8), a câmara primária é selada 
e inicia-se o aumento de pressão. $\mathrm{Na}$ região posterior do êmbolo primário, o furo de alimentação (Item 6, figura 2.8) encarrega-se de mantê-la preenchida com fluido de freio.

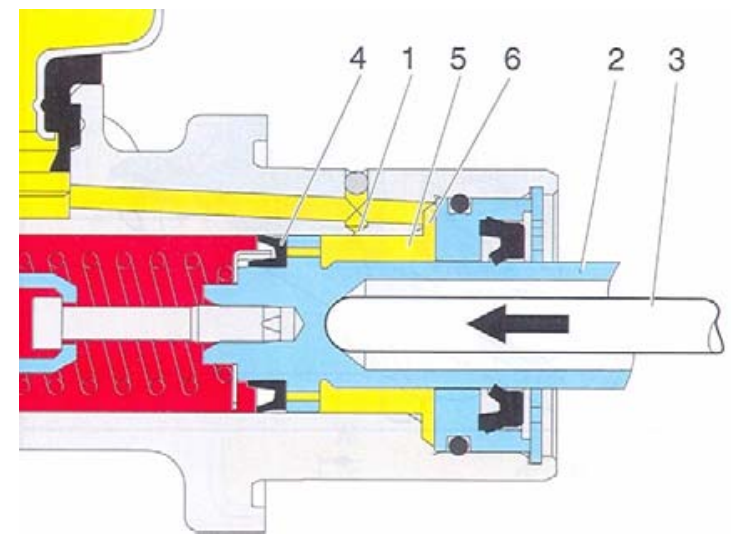

(1) furo de compensação; (2) êmbolo primário; (3) haste do cilindro mestre; (4) gaxeta de recuperação; (5) câmara anelar; (6) furo de alimentação.

Figura 2.8 - Cilindro mestre convencional durante a aplicação do freio (LUCAS, 1995a).

Praticamente ao mesmo tempo, o furo de compensação do êmbolo secundário é fechado e o aumento de pressão é iniciado. A diferença de pressão entre as duas câmaras é de até 0,5 bar (LUCAS, 1995a).

Quando o pedal é liberado, ambos os êmbolos retornam a posição de repouso, e, portanto, os freios de roda são liberados. Entretanto, a força das molas de retorno faz com que ambos os êmbolos retornem na sua posição de repouso muito mais rapidamente que o fluxo de fluido de freio. Deste modo, a diferença de pressão gerada pelo retorno dos êmbolos colapsa a gaxeta de recuperação (Item 4, figura 2.9), permitindo que haja fluxo de fluido pelos furos (Item 7, figura 2.9) do êmbolo primário (Item 2, figura 2.9), através do furo de alimentação (Item 6, figura 2.9), preenchendo a câmara primária e eliminando esta diferença de pressão. A mesma situação ocorre no êmbolo secundário. 


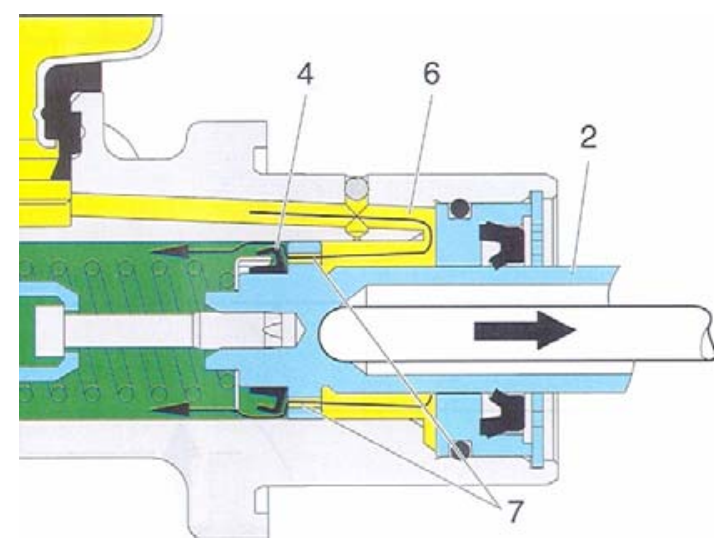

(2) êmbolo primário; (4) gaxeta de recuperação; (6) furo de alimentação;

(7) furos do êmbolo primário.

Figura 2.9 - Cilindro mestre convencional durante a liberação do freio (LUCAS, 1995a).

Para configurações de automóveis com sistema ABS, normalmente são utilizados cilindros mestres com válvula central. A figura 2.10 (Tipo 2) mostra um cilindro mestre com a válvula central incorporada no êmbolo secundário. Uma outra configuração possível é mostrada na figura 2.10 (Tipo3), com duas válvulas centrais, que é aplicado em veículos com sistemas de controle de tração ou ESP (LUCAS, 1995a).



Figura 2.10 - Tipos de cilindro mestre (LUCAS, 1995a). 
A utilização da válvula central nas aplicações com ABS se deve ao fato da possibilidade de ocorrência de danos nos lábios das gaxetas de vedação, como mostra a figura 2.11, durante o seu funcionamento, uma vez que picos de até 200 bar de pressão são aplicados no cilindro mestre decorrente da regulagem de pressão dos freios de roda, provocando movimentações longitudinais pulsantes em ambos os êmbolos primário e secundário. (LUCAS, 1995a).

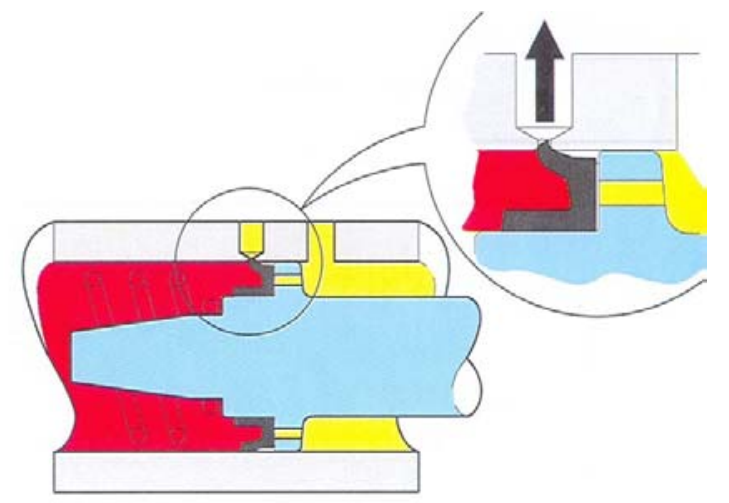

Figura 2.11 - Danos nos lábios da gaxeta de vedação num cilindro mestre convencional durante o funcionamento do ABS (LUCAS, 1995a).

As figuras 2.12, 2.13 e 2.14 mostram respectivamente as condições de operação da válvula central na posição de repouso (sem aplicação de força do pedal), durante a aplicação e na liberação do freio, na câmara secundária de um cilindro mestre.

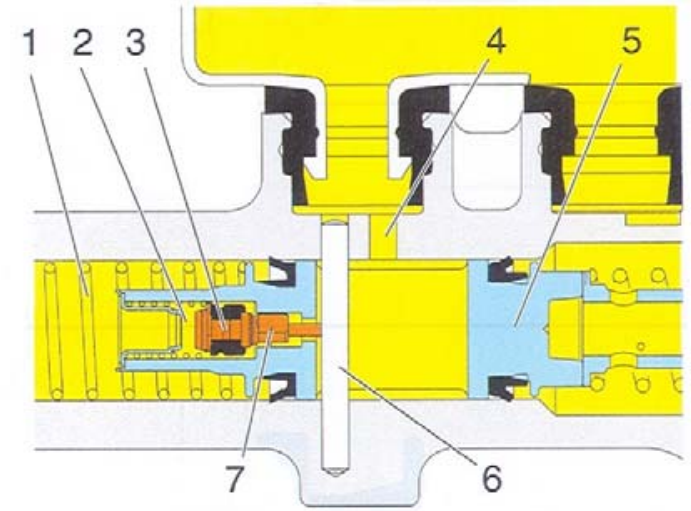

(1) mola de retorno do êmbolo; (2) mola de retorno da válvula central; (3) válvula central;

(4) canal de comunicação; (5) êmbolo secundário; (6) pino limitador;

(7) parte posterior da válvula central.

Figura 2.12 - Cilindro mestre com válvula central na posição de repouso

(LUCAS, 1995a). 
Na condição de repouso, o êmbolo secundário está encostado no pino limitador (Item 6, figura 2.12) através da força da mola de retorno do êmbolo (Item 1, figura 2.12). A parte posterior (Item 7, figura 2.12) da válvula central (Item 3, figura 2.12), da mesma forma encosta no pino limitador pela ação da mola de retorno da válvula central (Item 2, figura 2.12), mantendo a válvula aberta. A câmara secundária é alimentada pelo canal de comunicação da válvula central (Item 4, figura 2.12).

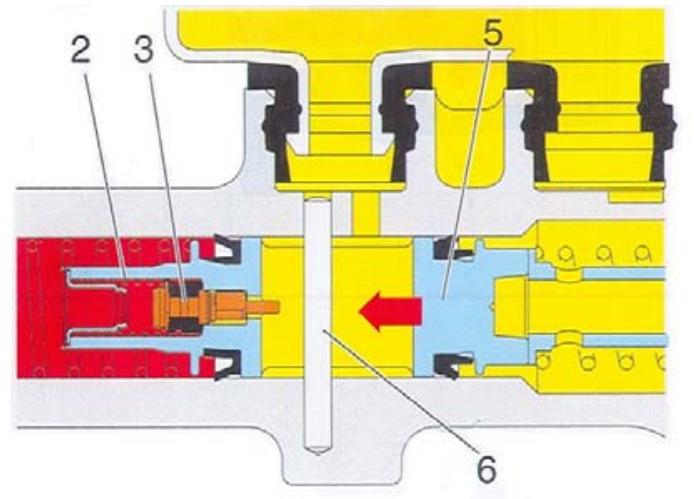

(2) mola de retorno da válvula central; (3) válvula central;

(5) êmbolo secundário; (6) pino limitador.

Figura 2.13 - Cilindro mestre com válvula central durante a aplicação do freio (LUCAS, 1995a).

Quando o pedal de freio é aplicado, o êmbolo secundário (Item 5, figura 2.13) inicia o movimento e a válvula central (Item 3, figura 2.13) é então pressionada contra a sua sede pela sua mola de retorno (Item 2, figura 2.13), fechando a comunicação entre a câmara secundária e o reservatório do cilindro mestre, e iniciando, deste modo, o aumento da pressão hidráulica no circuito de freio. 


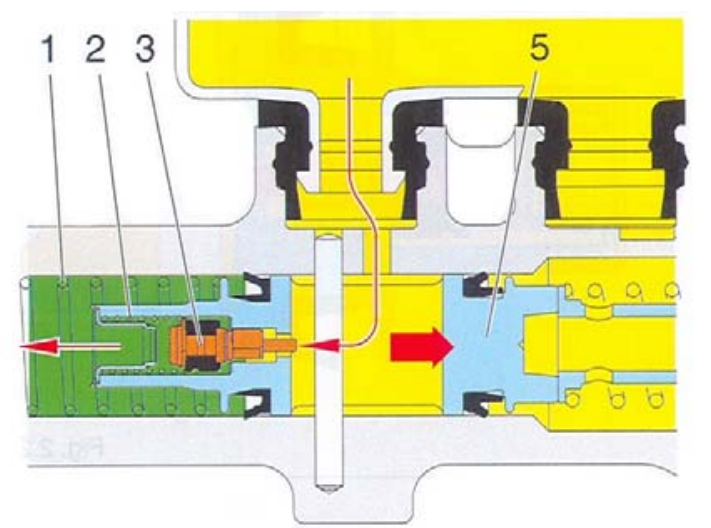

(1) mola de retorno do êmbolo; (2) mola de retorno da válvula central;

(3) válvula central;(5) êmbolo secundário.

Figura 2.14 - Cilindro mestre com válvula central durante a liberação do freio (LUCAS, 1995a).

Quando o pedal é liberado, a mola de retorno do êmbolo (Item 1, figura 2.14) movimenta o êmbolo secundário (Item 5, figura 2.14) para que retorne à sua posição de repouso rapidamente. Este retorno rápido gera uma diferença de pressão entre a câmara secundária e a antecâmara que está ligada ao reservatório do cilindro mestre, permitindo o fluxo de fluido com a abertura da válvula central, apesar da força que a mola de retorno da válvula central (Item 2, figura 2.14) exerce sobre a válvula. Ao retornar o êmbolo secundário à sua posição de repouso, a válvula central fica novamente aberta pelo pino limitador.

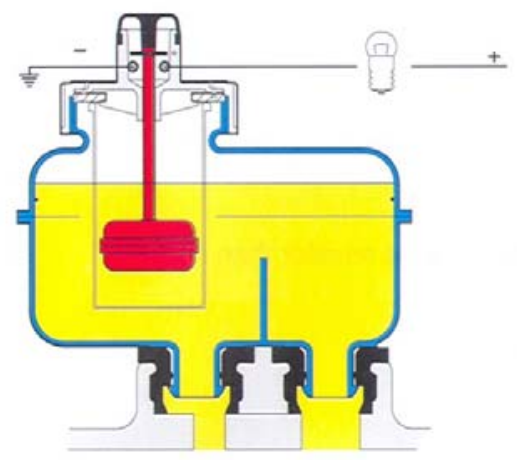

Figura 2.15 - Reservatório do Cilindro Mestre (LUCAS, 1995a).

O reservatório de fluido de freio, conforme mostrado na figura 2.15, é um componente integrante do cilindro mestre, que pode estar conectado remotamente, ou como na maior parte dos veículos, conectado diretamente ao cilindro mestre. Sua função básica é 
não só servir como reservatório de fluido do sistema, mas também compensar as flutuações de volume que ocorrem durante o funcionamento do sistema de freio. Estas flutuações ocorrem devido às variações de temperatura ambiente, liberação dos freios após a aplicação, desgaste das pastilhas e lonas das sapatas de freio ou devido ao funcionamento dos sistemas ABS e/ou ESP (LUCAS,1995a).

Nos veículos modernos, os reservatórios são normalmente produzidos com materiais plásticos translúcidos, de modo que possamos visualizar o nível do seu conteúdo. Um dispositivo indicador do nível de fluido pode estar acoplado à tampa, conforme mostrado na figura 2.15 , ou no interior do reservatório, e permite que uma lâmpada de advertência seja ligada quando o nível atingir um nível abaixo do mínimo especificado.

\subsubsection{Freio a Tambor}

Os freios a tambor representam um dos freios de roda comumente utilizados nos modernos automóveis de passeio, devido ao seu baixo custo comparado aos freios a disco (BAUER, 2003). Seu princípio básico de funcionamento consiste na geração de força de frenagem através do contato das lonas que revestem as sapatas na superfície interna do tambor por meio de sua movimentação radial provida pela ação de um atuador hidráulico, o cilindro de roda.

Devido a fatores construtivos, os freios a tambor podem ser divididos em 5 tipos principais, a saber (LIMPERT, 1999; BAUER, 2003):

- Simplex ou com sapatas “leading-trailing” (Itens a e b, figura 2.16);

- Duplex ou com sapatas “two-leading" (Item a, figura 2.17);

- Duo-duplex ou com sapatas "full two-leading" (Item b, figura 2.17);

- Uni-servo (Item a, figura 2.18);

- Duo-servo (Item b, figura 2.18); 

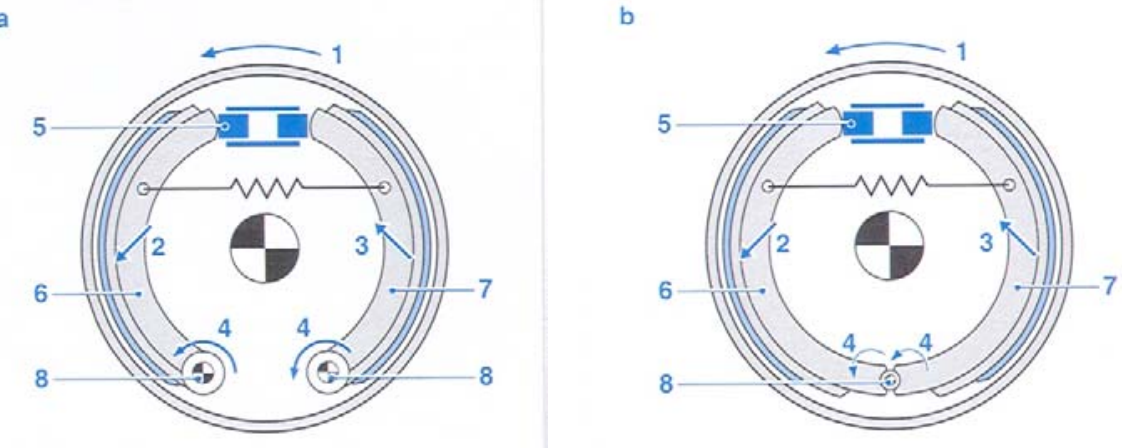

(1) direção de rotação; (2) efeito auto-energizamento; efeito auto-inibimento; (4) torque; (5) cilindro de roda de dupla ação; (6) e (7) sapatas; (8) ponto de ancoragem.

Figura 2.16 - Freio a tambor simplex (BAUER, 2003).
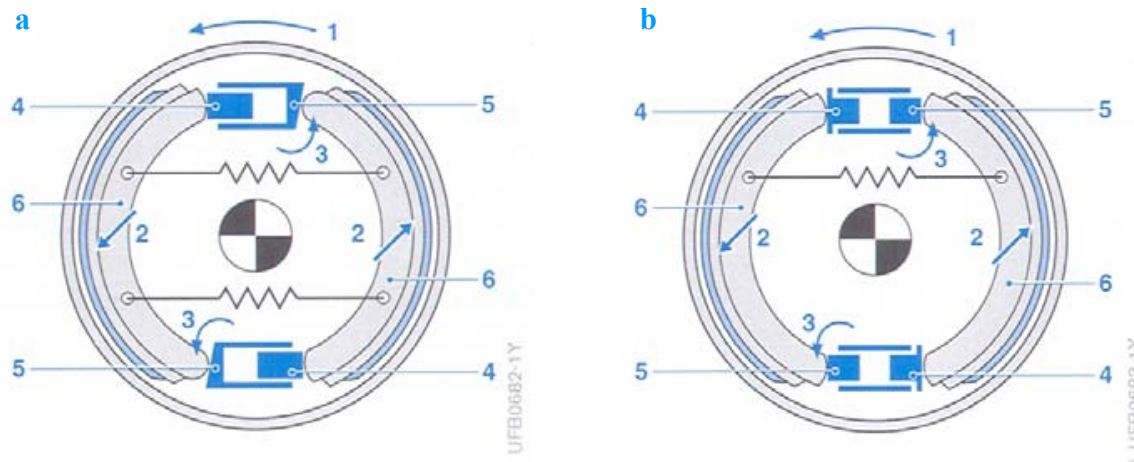

(1) direção de rotação; (2) efeito auto-energizamento; (3) torque; (4) cilindro de roda; (5) ponto de apoio; (6) sapatas de freio.

Figura 2.17 - Freio a tambor duplex (a) e duo-duplex (b) (BAUER, 2003).
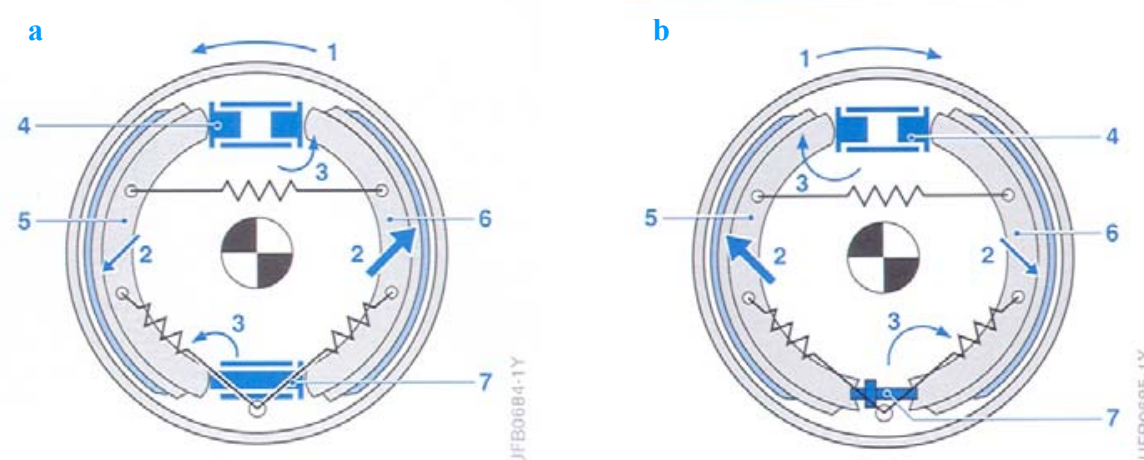

(1) direção de rotação; (2) efeito auto-energizamento; (3) torque; (4) cilindro de roda;

(5) ponto de apoio; (6) sapatas de freio; (7) pino de pressão.

Figura 2.18 - Freio a tambor uni-servo (a) e duo-servo (b) (BAUER, 2003). 
Dentre os diversos freios a tambor, o tipo simplex é o mais utilizado nos automóveis de passeio. A figura 2.19 mostra um típico freio a tambor simplex.

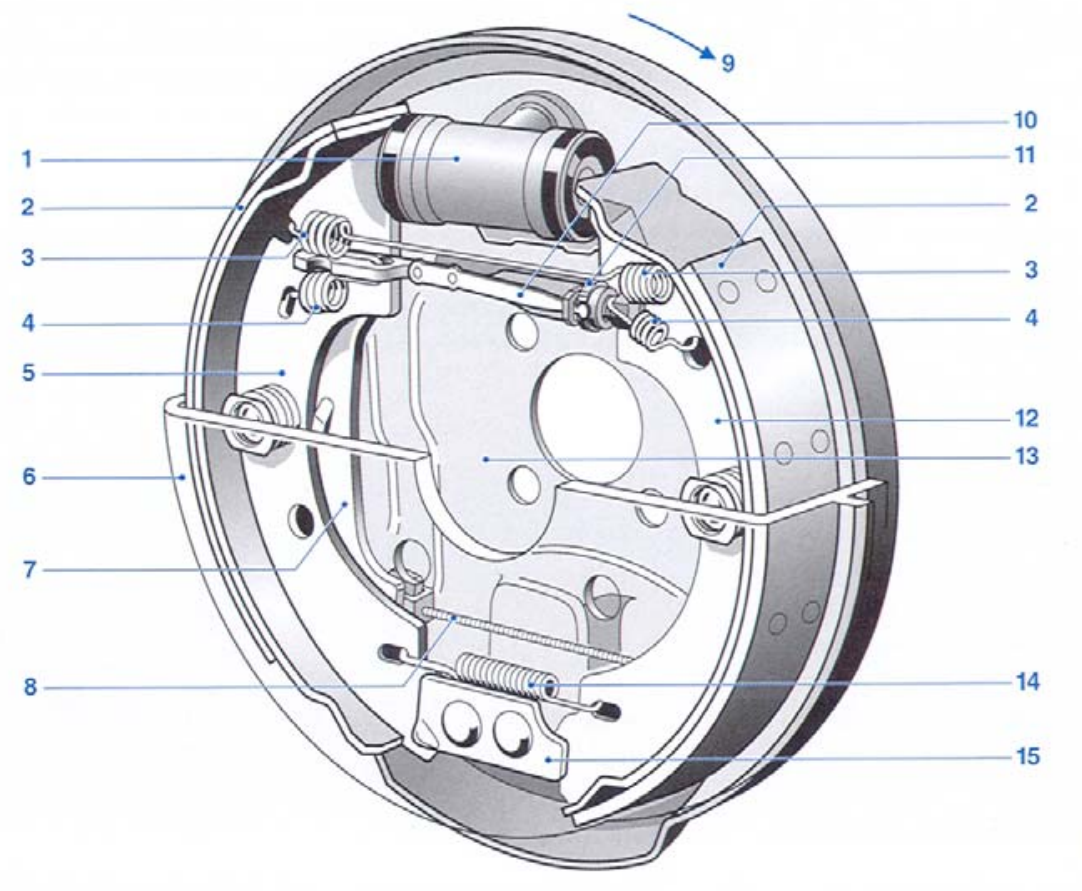

(1) cilindro de roda; (2) lona; (3) mola de retorno da sapata; (4) mola de retorno do mecanismo de auto-ajuste; (5) sapata de freio; (6) tambor de freio; (7) alavanca do freio de estacionamento; (8) cabo do freio de estacionamento; (9) sentido de rotação do tambor; (10) lâmina bi-metálica do mecanismo de auto-ajuste; (11) porca do mecanismo de autoajuste; (12) sapata de freio; (13) prato do freio; (14) mola de retorno; (15) placa de apoio.

Figura 2.19 - Freio a tambor simplex com mecanismo de freio de estacionamento (BAUER, 2003).

No caso do freio a tambor simplex, a pressão aplicada pelo fluido de freio através do cilindro mestre, atua sobre a câmara interna do cilindro de roda de dupla ação (Item 1, figura 2.19), movimentando os dois êmbolos que estão em contato com as sapatas de freio (Itens 5 e 12, figura 2.19), afastando-as. As sapatas, por sua vez giram em torno da placa de apoio (Item 15, figura 2.19), entrando em contato o tambor de freio, gerando assim, o torque de frenagem. 

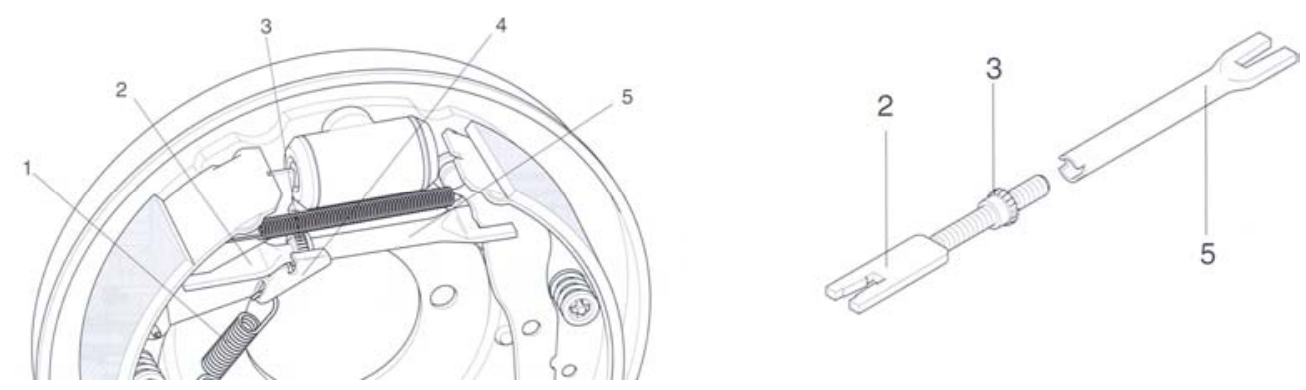

(1) mola da alavanca de ajuste; (2) fuso de ajuste roscado; (3) porca de ajuste dentada;

(4) alavanca de ajuste; (5) corpo do suporte.

Figura 2.20 - Mecanismo de regulagem automática do freio a tambor (LUCAS, 1995b).

Conforme o uso do freio, ocorre o desgaste das lonas e tambor, aumentando a folga entre ambas e por conseqüência, aumentando o curso morto do pedal de freio, ou seja, o curso de pedal que efetivamente não resulta em nenhuma força efetiva de frenagem. Para compensar o desgaste e evitar o aumento do curso morto, mecanismos de regulagem automática, conforme figura 2.20, são utilizados (BAUER, 2003). Estes mecanismos podem ser tanto acionados pelos freios de serviço quanto pelo freio de estacionamento. Em casos onde a aplicação de frenagem seja freqüente e com grande intensidade, a dilatação do tambor pode permitir uma regulagem do mecanismo acima do necessário, causando um sobre-ajuste que poderá travar o freio. Para evitar estas situações, são adicionados dispositivos compensadores térmicos bimetálicos (Item 4, figura 2.21) que compensam a dilatação térmica do tambor, evitando assim, o mau funcionamento do mecanismo de regulagem automática (LUCAS, 1995b).
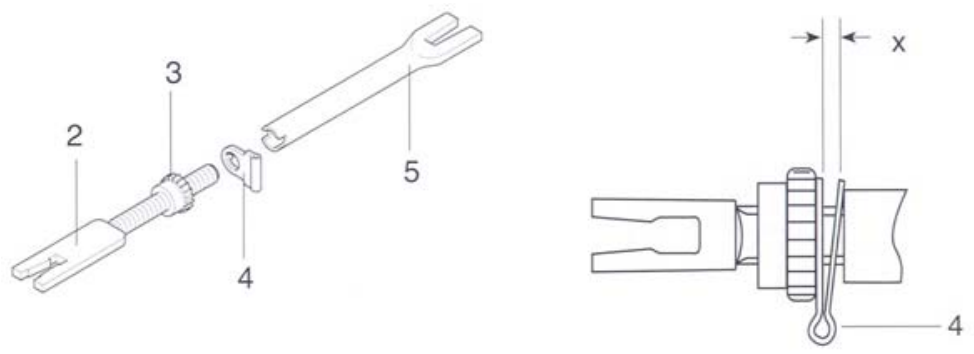

(2) fuso de ajuste roscado; (3) porca de ajuste dentada; (4) compensador térmico; (5) corpo do suporte.

Figura 2.21 - Regulagem automática com compensação térmica (LUCAS, 1995b). 
Segundo Gillespie (1992), a utilização dos freios a tambor se deve ao seu alto fator de freio, que é a razão entre a força de frenagem produzida pelo atrito entre as lonas e o tambor, e a força aplicada nas lonas contra o tambor. A figura 2.22 mostra um comparativo dos fatores de freio para diferentes tipos de freio a tambor e para o freio a disco, em função do coeficiente de atrito dos materiais (lona ou pastilha) e da velocidade inicial de frenagem (BAUER, 2003).
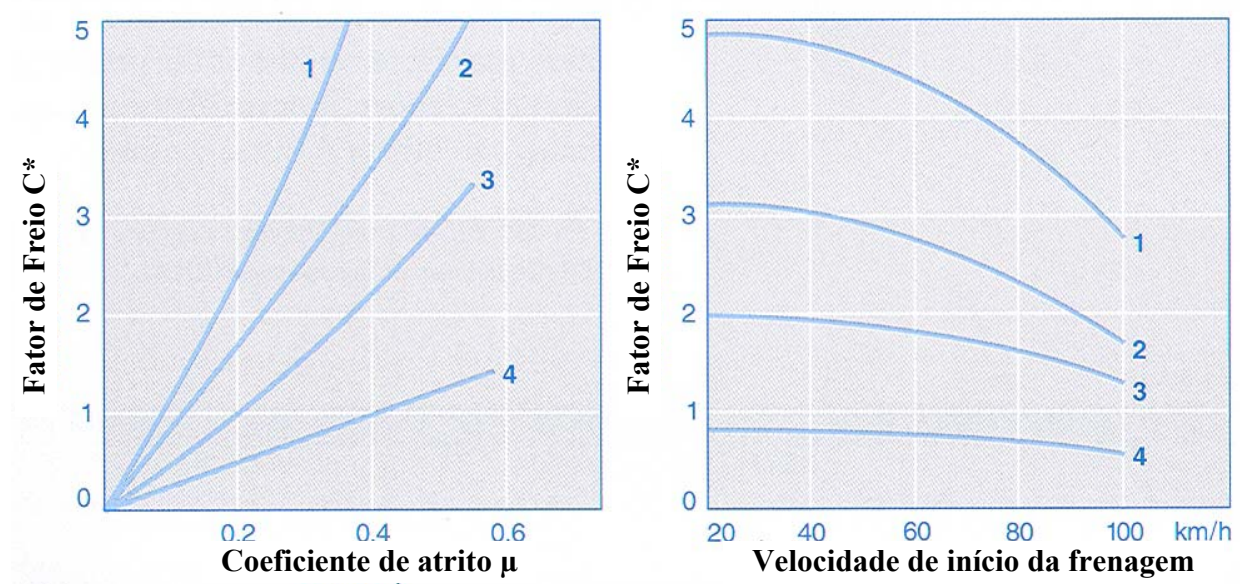

(1) freio a tambor duo-servo; (2) freio a tambor duo-duplex;

(3) freio a tambor simplex; (4) freio a disco.

Figura 2.22 - Fatores de freio $C^{*}$ em função do coeficiente de atrito e velocidade de início da frenagem (BAUER, 2003)

Ainda segundo Gillespie (1992), outra característica dos freios a tambor é a fácil incorporação de sistemas de freio de estacionamento, como se pode observar na figura 2.19 .

No entanto, segundo Limpert (1999), os freios a tambor não apresentam um comportamento linear entre o torque de freio e o coeficiente de atrito, de modo que pequenas variações do nível de atrito das lonas resultem em grandes variações de torque de frenagem.

Além disso, são freios altamente sensíveis à temperatura, não podendo exceder faixas de trabalho limites entre $400{ }^{\circ} \mathrm{C}$ a $500{ }^{\circ} \mathrm{C}$, devido à temperatura não só influenciar na degradação dos níveis de atrito lona/tambor, mas promover a dilatação térmica do tambor 
aumentando o seu diâmetro interno. Estes dois fatores podem influenciar diretamente o esforço e o curso de pedal de freio, ou seja, o conforto de frenagem.

Deste modo, pode-se observar a aplicação de freios a tambor principalmente nos eixos traseiros dos veículos modernos, ficando os freios a disco, de comportamento mais linear e mais robusto aos altos níveis de calor gerados durante a frenagem aplicados aos eixos dianteiros (BAUER, 2003).

\subsubsection{Freios a disco}

O freio a disco representa o outro tipo de freios de roda comumente utilizado nos automóveis de passeio. Seu princípio básico de funcionamento consiste na geração de força de frenagem através do contato das pastilhas nas superfícies laterais do disco por meio de sua movimentação axial provida pelo êmbolo do conjunto freio a disco ou "caliper", como também é conhecido.

Segundo Limpert (1999), a maior vantagem do uso de freios a disco baseia-se no fato de sua baixa degradação em desempenho a altas temperaturas, de até $800{ }^{\circ} \mathrm{C}$ a $900{ }^{\circ} \mathrm{C}$. O aumento da espessura devido à dilatação do disco de freio decorrente da frenagem não causa perda de volume do fluido de freio, isto é, não causa nenhum aumento de curso de pedal, nem afeta de modo algum o conforto de frenagem. Além disso, apresenta comportamento linear entre o torque de frenagem e o coeficiente de atrito entre pastilha e disco.

Baseado na sua forma construtiva, os freios a disco podem ser divididos em freio a disco tipo fixo e tipo flutuante, conforme figura 2.23. 

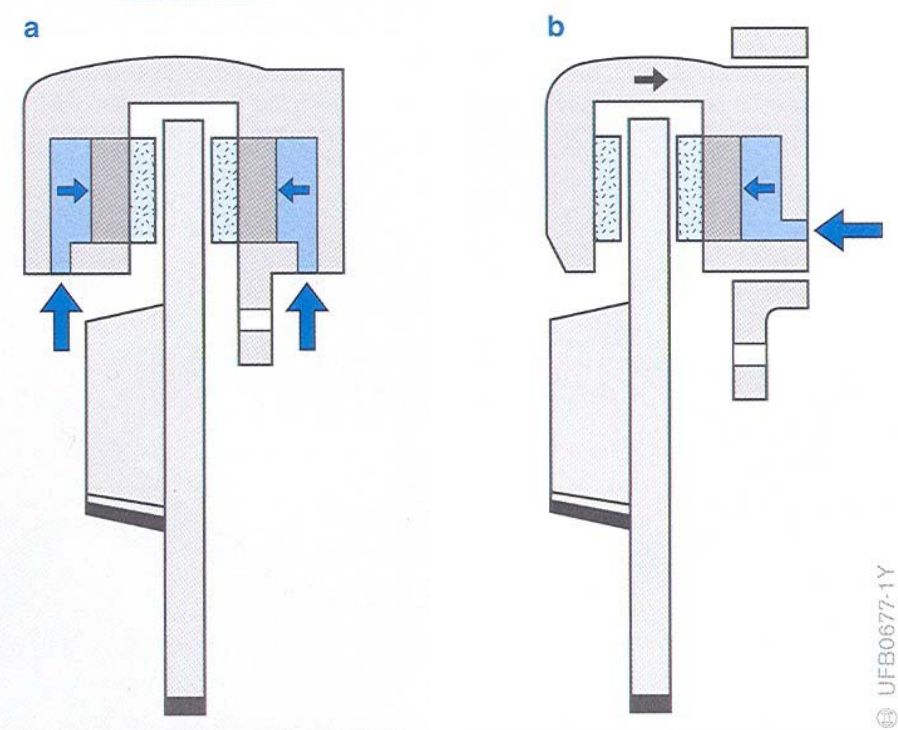

Figura 2.23 - Tipos de freios a disco: (a) tipo fixo; (b) tipo flutuante (BAUER, 2003).

Diferente dos freios a tambor que necessitam de um mecanismo auxiliar para realizar a regulagem automática, os freios a disco devido a sua concepção são auto-reguláveis. A figura 2.24 mostra o princípio de funcionamento. $\mathrm{O}$ anel de vedação (Item 1, da figura 2.24) é projetado de modo a sofrer deformação elástica (figura 2.24(b)). Durante a aplicação do freio, ao mesmo tempo em que permite o deslocamento relativo do êmbolo (Item 4, da figura 2.24), acompanha o desgaste da pastilha e do disco. Quando o freio é liberado, o anel de vedação arrasta o êmbolo até a sua posição de repouso (figura 2.24(a)), gerando uma folga entre o disco e pastilha da ordem de $0,15 \mathrm{~mm}$, permitindo que o disco gire livremente (BAUER, 2003). 
a

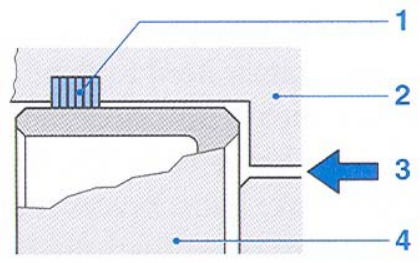

b



(a) freio não aplicado; (b) freio aplicado;

(1) anel de vedação; (2) corpo do caliper; (3) orifício de entrada de fluído; (4) êmbolo.

Figura 2.24 - Mecanismo de auto-regulagem dos freios a disco (BAUER, 2003).

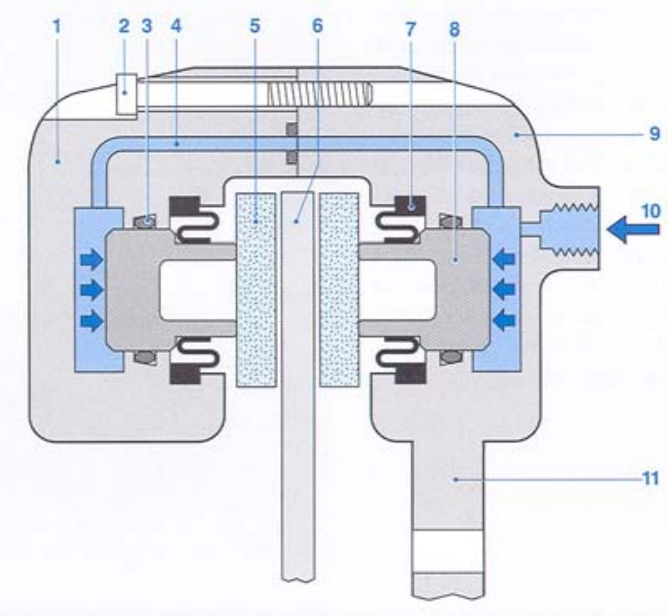

(1) carcaça externa; (2) parafuso de junção; (3) anel de vedação; (4) canal de fluido;

(5) pastilha de freio; (6) disco de freio; (7) guarda-pó de borracha; (8) êmbolo;

(9) carcaça interna flangeada; (10) furo de alimentação do fluido; (11) flange de montagem.

Figura 2.25 - Freio a disco tipo fixo (BAUER, 2003).

Um freio a disco tipo fixo (figura 2.25) pode possuir dois êmbolos (Item 8, da figura 2.25) localizados em lados opostos ou quatro êmbolos localizados em lados opostos, dois a dois, que movimentam as pastilhas (Item 5, da figura 2.25) contra o disco (Item 6, da figura 2.25) quando é aplicada pressão hidráulica pelo furo de alimentação (Item 10, da figura 2.25). Desta forma, a força de contato pastilha/disco gera a força de frenagem do veículo. 
Segundo Kakihara e Matsuzaki apud Breuer (2003), os freios a disco tipo fixo caracterizam-se por serem mais leves e mais robustos que os do tipo flutuante, que serão apresentados a seguir. Sua robustez resulta em baixa absorção volumétrica. Além disso, apresenta um desgaste de pastilha interna e externa mais balanceada, com baixo desgaste cônico comparado aos freios a disco flutuantes (LIMPERT, 1999).



(1) suporte; (2) pino-guia; (3) carcaça; (4) pastilha de freio externa; (5) disco de freio;

(6) pastilha de freio interna; (7) anel de vedação; (8) furo de alimentação do fluido;

(9) êmbolo; (10) carcaça; (11) guarda-pó de borracha.

Figura 2.26 - Freio a disco tipo flutuante (BAUER, 2003).

Um freio a disco tipo flutuante (figura 2.26) pode possuir um êmbolo (Item 9, figura 2.26) ou dois êmbolos localizados no lado interno da carcaça, que também é denominado cilindro de roda (Item 10, figura 2.26) que movimenta a pastilha interna (Item 6, figura 2.26) contra o disco de freio (Item 5, figura 2.26), quando é aplicada pressão hidráulica pelo furo de alimentação (Item 8, figura 2.26). Ao mesmo tempo, a pressão hidráulica desloca a carcaça no sentido oposto ao êmbolo, movimentando a pastilha externa (Item 4, figura 2.26) contra o disco de freio.

Segundo Limpert (1999), os freios a disco flutuantes apresentam uma série de vantagens comparados ao do tipo fixo. Caracterizam-se pela facilidade de instalação nas 
rodas, uma vez que não possuem pistões no lado externo, próximo às rodas. Além disso, apresentam temperaturas de trabalho do fluido de freio menores que os do tipo fixo, devido a inexistência de circulação do fluido próximo às áreas de geração de calor e onde há baixa circulação de ar para arrefecimento, evitando potencial vaporização do fluido de freio. Também tem a possibilidade de serem providos de mecanismos de freio de estacionamento (figura 2.27), onde uma alavanca externa aciona um mecanismo de esferas em canais em forma de rampa, movimentando mecanicamente o êmbolo, que por sua vez, aplica força sobre as pastilhas.



(1) carcaça; (2) pino guia; (3) pastilha de freio externa; (4) disco de freio;

(5) pastilha de freio interna; (6) êmbolo; (7) guarda-pó de borracha; (8) carcaça;

(9) mecanismo de auto-ajuste; (10) envólucro metálico; (11) furo de alimentação de fluido;

(12) haste; (13) disco de vedação; (14) tampa da carcaça; (15) came; (16) alavanca;

(17) alavanca do freio de estacionamento; (18) anel de vedação; (19) mola; (20) folga.

Figura 2.27 - Freio a disco flutuante com mecanismo de freio de estacionamento (BAUER, 2003).

A desvantagem principal dos freios a disco flutuante consiste no maior potencial de torque residual decorrente do arraste da pastilha. Este fato se deve ao retorno insuficiente do anel de vedação do êmbolo, quando a pressão hidráulica do freio é liberada. A existência de um número maior de graus de liberdade comparado aos do tipo fixo, tornam estes mais suscetíveis a ocorrência de ruídos. 


\subsection{6 - Dispositivos de controle de pressão}

Desconsiderando outras forças resistivas ao movimento do veículo, tais como força aerodinâmica e a força de rolamento na frenagem de um veículo, a força que atua no centro de gravidade (CG) causa uma "transferência dinâmica de carga" (REIMPELL; STOLL; BETZLER, 2001). Desta forma, este efeito de transferência dinâmica de carga provoca alterações nas forças normais de reação pneu-pavimento, que por conseqüência influenciam diretamente a máxima força de frenagem a ser aplicada em cada eixo. A figura 2.28 mostra o efeito da transferência dinâmica de carga.


(a) veículo na condição estática; (b) veículo na condição de frenagem.

\section{Figura 2.28 - Efeito da transferência dinâmica de carga (LUCAS, 1995a).}

Neste comportamento dinâmico do veículo durante a frenagem, em que as forças de frenagem aplicadas pelo sistema de freio, são maiores que as forças máximas de frenagem possível pela condição de aderência pneu-pavimento, podemos ter uma condição de travamento do eixo. Segundo Reimpell, Stoll e Betzler (2001), o travamento traseiro representa uma condição instável no comportamento dinâmico do veículo.

A figura 2.41 mostra o gráfico do comportamento das forças de frenagem dianteira e traseira de um veículo para cada condição pneu-pavimento. A curva parabólica representa a curva das força máximas de frenagem dianteira e traseira para cada condição de aderência entre pneu-pavimento. Nesta ocasião, ocorre o travamento dos eixos dianteiro e traseiro simultaneamente, e esta é denominada curva de distribuição ótima de frenagem. $\mathrm{O}$ 
comportamento da força de frenagem do sistema de freio instalado no veículo é representado pela reta no gráfico da figura 2.41. Deste modo, uma frenagem numa condição acima da curva ótima, como o ponto $\mathrm{P}_{3}$ resultará na ocorrência do travamento do eixo traseiro.

Assim sendo, o projeto de um sistema de freio de um veículo deve ter como objetivo desempenhar forças de frenagem o mais próxima possível da curva de distribuição ótima de frenagem, de modo a utilizar a máxima eficiência disponível que os freios de roda permitem. Entretanto, numa instalação normal somente contendo o conjunto servofreio/cilindro mestre e os freios de roda dianteiros (freio a disco) e traseiros (freios a disco ou a tambor) não seria possível obter tal condição para todas as condições de pista, uma vez que a relação de frenagem instalada seria uma constante (figura 2.29) (LUCAS, 1995a).
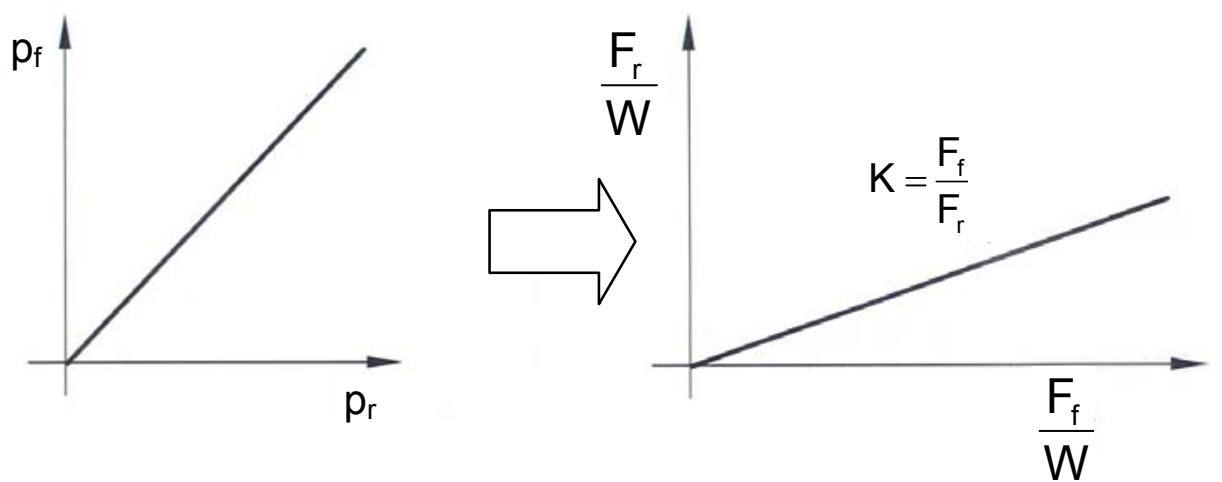

$\mathrm{p}_{\mathrm{f}}$ : Pressão do sistema de freio, eixo dianteiro; $\mathrm{p}_{\mathrm{r}}$ : Pressão do sistema de freio, eixo traseiro; $\mathrm{F}_{\mathrm{f}}$ : Força de frenagem, eixo dianteiro; $\mathrm{F}_{\mathrm{r}}$ : Força de frenagem, eixo traseiro; $\mathrm{W}$ : peso do veículo; $\mathrm{K}$ : relação de freio instalado

Figura 2.29 - Curva de distribuição de frenagem instalada (LUCAS, 1995a).

A utilização de dispositivos de controle de pressão no sistema de freio permite que a força de frenagem real do veículo se aproxime da condição de frenagem ótima. Os dispositivos de controle de pressão podem ser divididos basicamente em duas categorias principais: válvulas limitadoras de pressão e válvulas reguladoras ou redutoras de pressão. Dentre as duas, as válvulas reguladoras de pressão são as mais utilizadas, dentre as quais destacam-se (BAUER, 2003): 
- Válvula redutora de pressão com ponto de pressão de corte fixo, ou, válvula de corte fixo;

- Válvula redutora de pressão com ponto de pressão de corte proporcional à carga, ou, válvula sensível à carga;

- Válvula redutora de pressão com ponto de pressão de corte proporcional à desaceleração, ou, válvula sensível à desaceleração.

Dentre as válvulas acima mencionadas, as de corte fixo e as sensíveis à carga são as que possuem maior utilização nos veículos.

As válvulas de corte fixo são as mais utilizadas nos automóveis de passeio, devido ao seu baixo custo e à simplicidade na sua aplicação. Nestas válvulas, a taxa de aumento da pressão nos freios traseiros é menor que nos freios dianteiros, acima de uma pressão específica, denominado pressão de corte da válvula, ou ponto de corte. A figura 2.30 mostra o comportamento da válvula de corte fixo.



(1) pressão não regulada; (2) curva de pressão ideal (veículo carregado); (3) pressão regulada; (4) curva de pressão ideal (veículo em ordem de marcha); (5) ponto de corte.

Figura 2.30 - Comportamento da válvula de corte fixo (BAUER, 2003).

O funcionamento deste tipo de válvula é constante, independente das condições de carregamento do veículo, o que pode resultar na sobrecarga do freio dianteiro, caso as diferenças de carga sejam muito expressivas entre a condição de veículo somente com 
motorista e na condição de carregamento máximo permitido, como no caso de veículos comerciais, tais como as caminhonetas, onde são possíveis variações entre $55 \%$ a $65 \%$ de massa entre as duas condições de carregamento do veículo.

As válvulas sensíveis à carga são as mais utilizadas por veículos que apresentam variações de cargas entre os limites inferior e superior que possam substancialmente afetar a posição do centro de gravidade do veículo, tal como ocorre nas caminhonetas. Entretanto, devido ao seu refinamento quanto a regulagem de pressão, podemos perceber o seu uso também em automóveis de passeio, mesmo compactos.



(a) veículo carregado; (b) veículo em ordem de marcha;

(1) êmbolo graduado; (2) mola de controle externa; (3) pressão para os freios;

(4) pressão do cilindro mestre; (5) mecanismo articulado de barras; (6) eixo traseiro.

Figura 2.31 - Válvula sensível à carga (BAUER, 2003).

Este dispositivo, como mostra a figura 2.31 constitui-se basicamente de uma válvula de corte fixo anexo a uma mola de controle externa (Item 2, figura 2.31), a qual altera o ponto de corte da válvula, dependendo do movimento relativo da suspensão que é transmitido através de um mecanismo articulado de barras (Item 5, figura 2.31). A figura 2.32 mostra o comportamento da válvula sensível à carga, para diversos carregamentos, e 
apresentando os pontos de corte numa condição de carregamento mínimo e máximo do veículo.

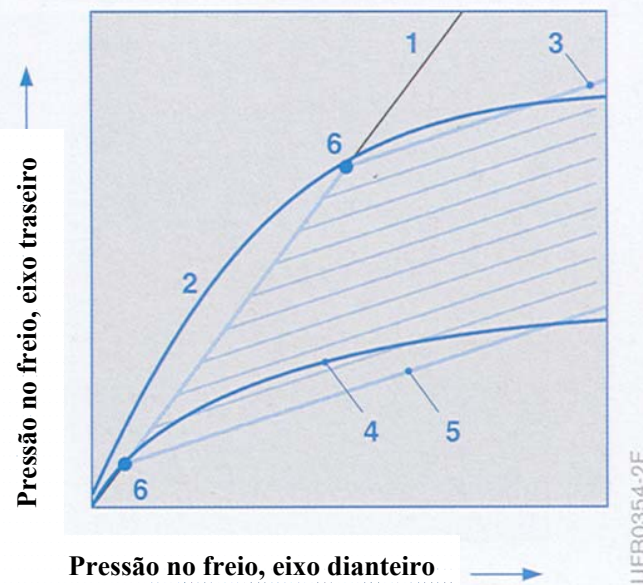

(1) pressão não reduzida; (2) curva de pressão ideal (veículo carregado); (3) pressão reduzida (veículo carregado); (4) curva de pressão ideal (veículo em ordem de marcha);

(5) pressão reduzida (veículo em ordem de marcha); (6) pontos de corte.

Figura 2.32 - Comportamento da válvula sensível à carga (BAUER, 2003).

\subsubsection{Configurações do circuito hidráulico do freio}

Para atender aos requisitos estabelecidos pelas normas regulamentadoras, o sistema de freio deve incorporar circuitos duplos e independentes, com o objetivo de prevenir a perda total do sistema de freio, em caso de ocorrência de alguma falha no sistema, como por exemplo, vazamento no circuito.

Segundo Bauer (2003), a norma DIN 74000 informa que o circuito hidráulico do freio pode ser configurado de 5 formas diferentes, conforme a figura 2.33 . 



(a) configuração II, vertical ou paralela; (b) configuração X ou diagonal; (c) configuração HI; (d) configuração LL; (e) configuração HH; (1) circuito 1; (2) circuito 2; $(\leftarrow)$ sentido frontal.

Figura 2.33 - Configurações hidráulicas típicas do sistema de freio (BAUER, 2003).

Dentre os circuitos apresentados, os mais utilizados são as configurações II (vertical ou paralela) e X (diagonal). No circuito vertical, uma das câmaras do cilindro mestre alimenta os eixos dianteiros, enquanto a outra câmara alimenta os eixos traseiros. Já no circuito diagonal, uma das câmaras alimenta o freio dianteiro esquerdo e o freio traseiro direito, enquanto que a outra câmara alimenta o freio dianteiro direito e o freio traseiro esquerdo.

O circuito diagonal é utilizado em praticamente todos os automóveis de passeio, pois apresentam uma polarização de distribuição de carga mais dianteira. Já o circuito vertical é largamente utilizado em veículos utilitários e comerciais leves, os quais apresentam 
em geral uma polarização de distribuição de carga mais traseira.

\subsection{Revisão Teórica do Sistema de Freios}

Ao abordar-se uma breve revisão sobre os vários componentes que constituem o sistema de freio, é oportuno realizar uma revisão teórica dos conceitos associados à dinâmica de frenagem, antes de analisar o conforto, o qual é o propósito deste trabalho.

\subsubsection{O Conceito de Aderência}

Ao discutir-se o mecanismo do contato pneu-pavimento, é comum logo se relacionar às forças que agem nesta interface, tais como a força de tração e a de frenagem, diretamente com a força de atrito, baseada na lei de Coulomb. Contudo, este conceito não abrange totalmente a dinâmica envolvida no contato pneu-pavimento, pois o atrito segundo a lei de Coulomb, sendo independente da área de contato, não se justificaria os diferentes resultados obtidos por veículos utilizando pneus com diferentes bandas de rodagem.

De acordo com Gillespie (1992), o mecanismo de contato pneu-pavimento baseia-se pela ação de dois componentes primários: a aderência superficial e a histerese da banda de borracha. A figura 2.34 mostra como estes dois componentes atuam no pneu.

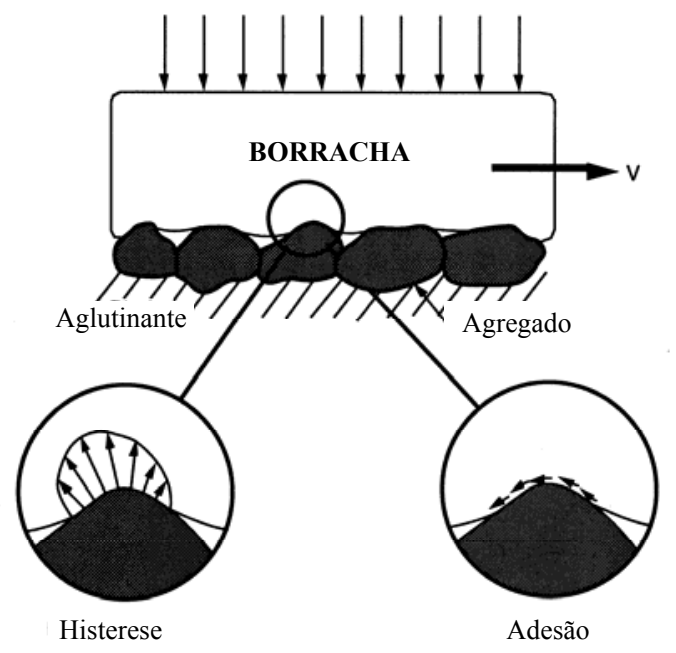

Figura 2.34 - Mecanismo de contato pneu-pavimento (GILLESPIE, 1992). 
A aderência superficial origina-se da ligação intermolecular entre a borracha e os elementos que compõe a superfície do pavimento, e portanto, varia conforme o atrito entre a borracha do pneu e a superfície do pavimento, resultando no desgaste do pneu.

Já a histerese da borracha representa a perda de energia em forma de calor decorrente da deformação da borracha do pneu sobre a superfície dos elementos que compõem o pavimento, e é pouco influenciada pelo atrito entre a borracha da banda e os elementos do pavimento.

Desta forma, baseando-se no mecanismo de contato pneu-pavimento, seria conveniente substituir o termo "coeficiente de atrito" por "coeficiente de adesão", ou simplesmente "aderência", apesar de muitos autores, tais como Limpert (1999) e Reimpell, Stoll e Betzler (2001) utilizarem o termo coeficiente de atrito para expressar o mesmo fenômeno.

Ainda segundo Gillespie (1992), durante o rolamento do pneu sobre o pavimento, tanto a aderência como a histerese do pneu, estão correlacionadas a escorregamentos infinitesimais ocorridas na interface pneu-pavimento. No momento em que ocorre uma frenagem em linha reta, um escorregamento adicional é observado como resultado da deformação dos elementos da borracha da banda do pneu, desenvolvendo e sustentando a força de frenagem.

Assim sendo, podemos observar que na frenagem, a velocidade tangencial da roda é menor devido ao escorregamento $(\lambda)$, que representa o quanto a velocidade tangencial do pneu se afasta da velocidade longitudinal da roda (figura 2.35), e é dada por: 



$\left(\mathrm{v}_{\mathrm{F}}\right)$ Velocidade no centro da roda, $\mathrm{M} ;\left(\mathrm{v}_{\mathrm{U}}\right)$ Velocidade tangencial.

Figura 2.35 - Roda rolando livre (a); roda sob frenagem (b) (BAUER, 2003).

$$
\lambda=\frac{\left(\mathrm{v}_{\mathrm{F}}-\mathrm{v}_{\mathrm{U}}\right)}{\mathrm{v}_{\mathrm{F}}}
$$

sendo que,

$\mathrm{V}_{\mathrm{F}}$ : velocidade linear longitudinal da roda

$\mathrm{V}_{\mathrm{U}}:$ velocidade tangencial do pneu

Quando um veículo descreve uma trajetória curvilínea com ou sem frenagem, a flexibilidade lateral do pneu gera uma força lateral $\left(\mathrm{F}_{\mathrm{s}}\right)$ decorrente do desvio do movimento do pneu em relação ao seu plano diametral (MADUREIRA, 2004).

A figura 2.36 mostra as forças que atuam no pneu no momento da frenagem, onde temos as forças de frenagem em cada eixo $\left(F_{f}\right.$ e $\left.F_{t}\right)$, a força lateral $\left(F_{s}\right)$ e as forças normais $\left(\mathrm{W}_{\mathrm{bf}}\right.$ e $\left.\mathrm{W}_{\mathrm{bt}}\right)$, que representam os "pesos dinâmicos" do veículo e serão descritas mais adiante. 




Figura 2.36 - Forças atuantes no pneu durante uma frenagem em curva (BAUER, 2003).

Devido a essa característica de flexibilidade do pneu, as forças de frenagem $\left(\mathrm{F}_{\mathrm{f}}\right.$ e $\left.F_{t}\right)$ e a força lateral $\left(F_{s}\right)$, dependentes respectivamente da aderência longitudinal e lateral do pneu, e o escorregamento coexistem e se relacionam mutuamente, como apresentado na figura 2.37 (MITSCHKE; WALLENTOWITZ, 2004). Além disso, observa-se a influência do ângulo de deriva $(\alpha)$ na aderência longitudinal e lateral, que representa o ângulo de desvio direcional do movimento do pneu na trajetória curvilínea. 


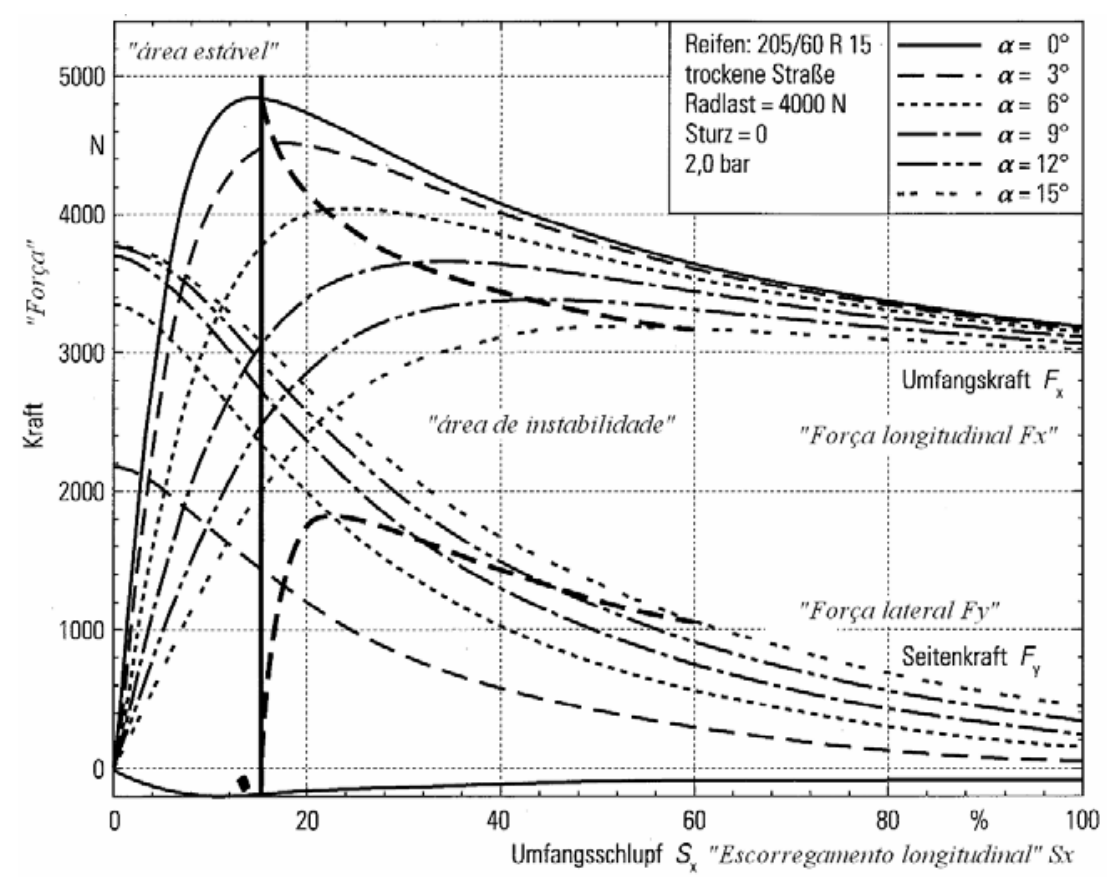

Figura 2.37 - Capacidade de transmissão de força no sentido longitudinal e lateral, em função do escorregamento longitudinal (pneu radial 205/60 R15 com 2 bar de pressão, carga dinâmica de 4000N e camber 0) (MITSCHKE; WALLENTOWITZ, 2004).

A força de frenagem derivada da aderência e da histerese do pneu cresce com o escorregamento até uma faixa entre $10 \%$ a $20 \%$, dependendo de certas condições, atingindo o seu máximo valor que corresponde à máxima capacidade de tração obtida na interface pneupavimento (GILLESPIE, 1992). Desta forma, podemos expressar para limites máximos de aderência, as seguintes relações:

$$
\begin{aligned}
& \mathrm{F}_{\mathrm{f}}=\mu_{\mathrm{f}} \cdot \mathrm{W}_{\mathrm{bf}} \\
& \mathrm{F}_{\mathrm{sf}}=\mu_{\mathrm{sf}} \cdot \mathrm{W}_{\mathrm{bf}} \\
& \mathrm{F}_{\mathrm{t}}=\mu_{\mathrm{t}} \cdot \mathrm{W}_{\mathrm{bt}} \\
& \mathrm{F}_{\mathrm{st}}=\mu_{\mathrm{st}} \cdot \mathrm{W}_{\mathrm{bt}}
\end{aligned}
$$

onde, $\mu_{\mathrm{f}}$ e $\mu_{\mathrm{sf}}$ indicam respectivamente as aderências longitudinais e laterais no pneu dianteiro e $\mu_{\mathrm{t}}$ e $\mu_{\mathrm{st}}$, as aderências no pneu traseiro.

Considerando que normalmente os automóveis de passeio utilizam pneus iguais tanto na dianteira quanto na traseira, podemos adotar que: 


$$
\begin{aligned}
& \mu_{\mathrm{f}}=\mu_{\mathrm{t}}=\mu_{\mathrm{HF}} \\
& \mu_{\mathrm{sf}}=\mu_{\mathrm{st}}=\mu_{\mathrm{s}}
\end{aligned}
$$

Segundo BAUER (2003), as condições que também influenciam o coeficiente de adesão seriam:

- O material do pavimento;

- O estado e o desenho das bandas do pneu;

- A velocidade do veículo sobre o pavimento;

- As condições climáticas;

- O peso dinâmico atuante em cada pneu no momento da frenagem.

A tabela 2.1 mostra a variação da aderência pneu-pavimento em função da velocidade do veículo, da condição climática e do estado do pneu.

\begin{tabular}{|c|c|c|c|c|c|c|}
\hline $\begin{array}{c}\text { Velocidade } \\
{[\mathrm{km} / \mathrm{h}]}\end{array}$ & $\begin{array}{l}\text { Estado dos } \\
\text { pneus }\end{array}$ & $\begin{array}{c}\text { Asfalto } \\
\text { seco } \\
\mu_{\mathrm{HF}}\end{array}$ & $\begin{array}{c}\text { Asfalto } \\
\text { molhado } \\
\text { (filme } 0,2 \mathrm{~mm} \text { ) } \\
\mu_{\mathrm{HF}}\end{array}$ & $\begin{array}{c}\text { Asfalto sob } \\
\text { chuva intensa } \\
\text { (filme 1 mm) } \\
\mu_{\mathrm{HF}}\end{array}$ & $\begin{array}{c}\text { Lâmina } \\
\text { d'água } \\
\text { (2mm) } \\
\mu_{\mathrm{HF}}\end{array}$ & $\begin{array}{l}\text { Gelo } \\
\mu_{\mathrm{HF}}\end{array}$ \\
\hline \multirow{2}{*}{50} & novo & 0,85 & 0,65 & 0,55 & 0,5 & 0,1 \\
\hline & desgastado & 1,00 & 0,50 & 0,4 & 0,25 & $<0,1$ \\
\hline \multirow{2}{*}{90} & novo & 0,80 & 0,60 & 0,3 & 0,05 & $<0,1$ \\
\hline & desgastado & 0,95 & 0,20 & 0,1 & 0 & $<0,1$ \\
\hline \multirow{2}{*}{130} & novo & 0,75 & 0,55 & 0,2 & 0 & $<0,1$ \\
\hline & desgastado & 0,90 & 0,20 & 0,1 & 0 & $<0,1$ \\
\hline
\end{tabular}

Tabela 2.1 - Valores típicos de aderência longitudinal

O comportamento da aderência pneu-pavimento para níveis maiores de escorregamento resulta na sua diminuição, após atingir o seu valor máximo, como mostrado no gráfico da figura 2.38, podendo estabelecer o comportamento da frenagem em duas áreas distintas: 
- a área de frenagem estável, até a aderência máxima, onde a frenagem é segura de modo que o motorista obtém o máximo desempenho do freio de seu veículo, além do controle direcional, e

- a área instável, onde a influência do escorregamento torna-se cada vez maior no comportamento dinâmico do pneu, tendendo ao travamento, condição essa que resulta além da queda no desempenho da frenagem, a total perda de controle direcional do veículo.

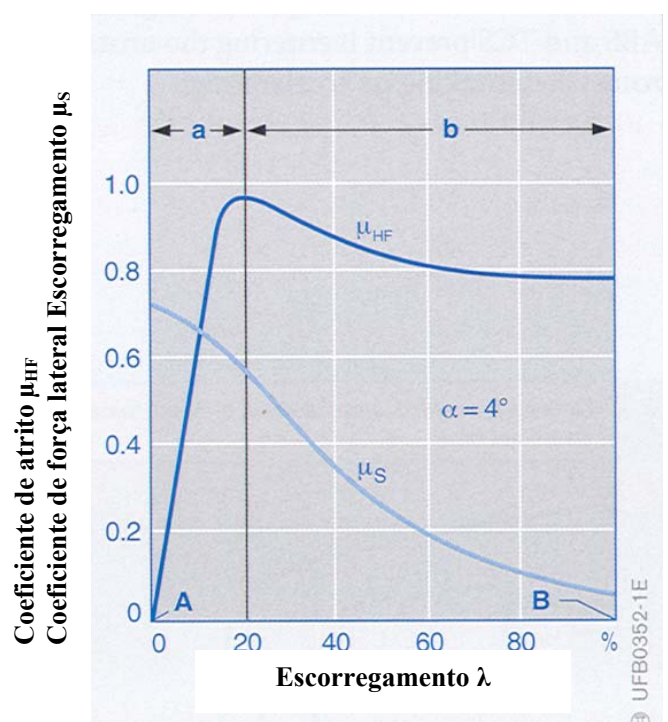

(a) zona estável; (b) zona instável; ( $\alpha$ ) ângulo de deriva; (A) roda rolando; (B) roda travada.

Figura 2.38 - Comportamento da aderência pneu-pavimento (BAUER, 2003).

\subsubsection{Dinâmica da frenagem}

A figura 2.39 abaixo mostra a representação de coordenadas padronizadas pela Society of Automovive Engineers (SAE), para automóveis, considerando o modelo de veículo onde a sua massa esteja concentrada no seu centro de gravidade (CG) (GILLESPIE, 1992). 


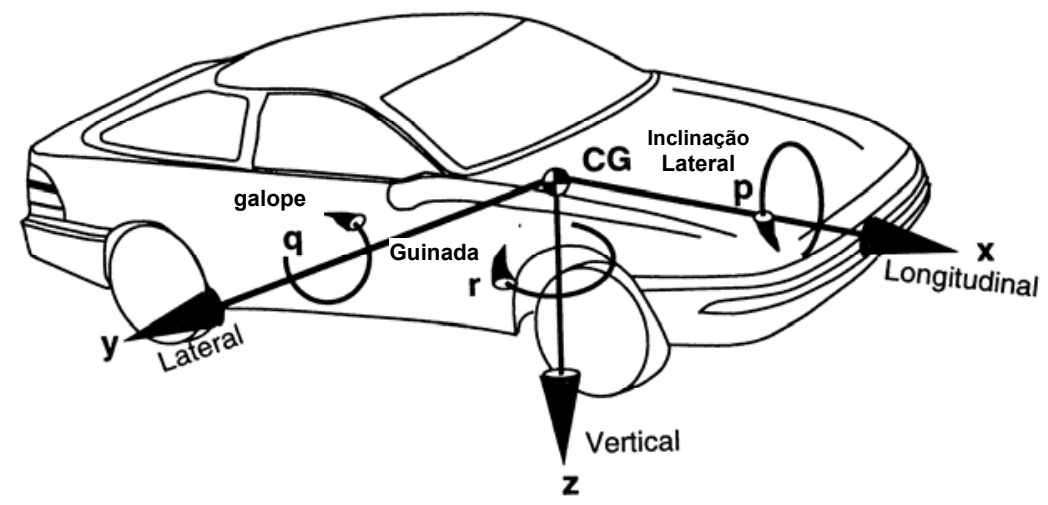

Figura 2.39 - Sistema de coordenadas conforme SAE J670e (GILLESPIE, 1992).

Durante a frenagem de um veículo, além da força gerada pelo sistema de freio através do acionamento do pedal de freio pelo motorista afetar a velocidade do veículo, outras forças resistivas ao movimento contribuem também com a sua parcela, tais como (MADUREIRA, 2004):

- Resistência aerodinâmica;

- Resistência ao rolamento;

- Resistência ao aclive, que decorre da ação da gravidade sobre o veículo ao se deslocar em pavimentos inclinados;

- Resistência de inércia das partes rotativas do veículo. 


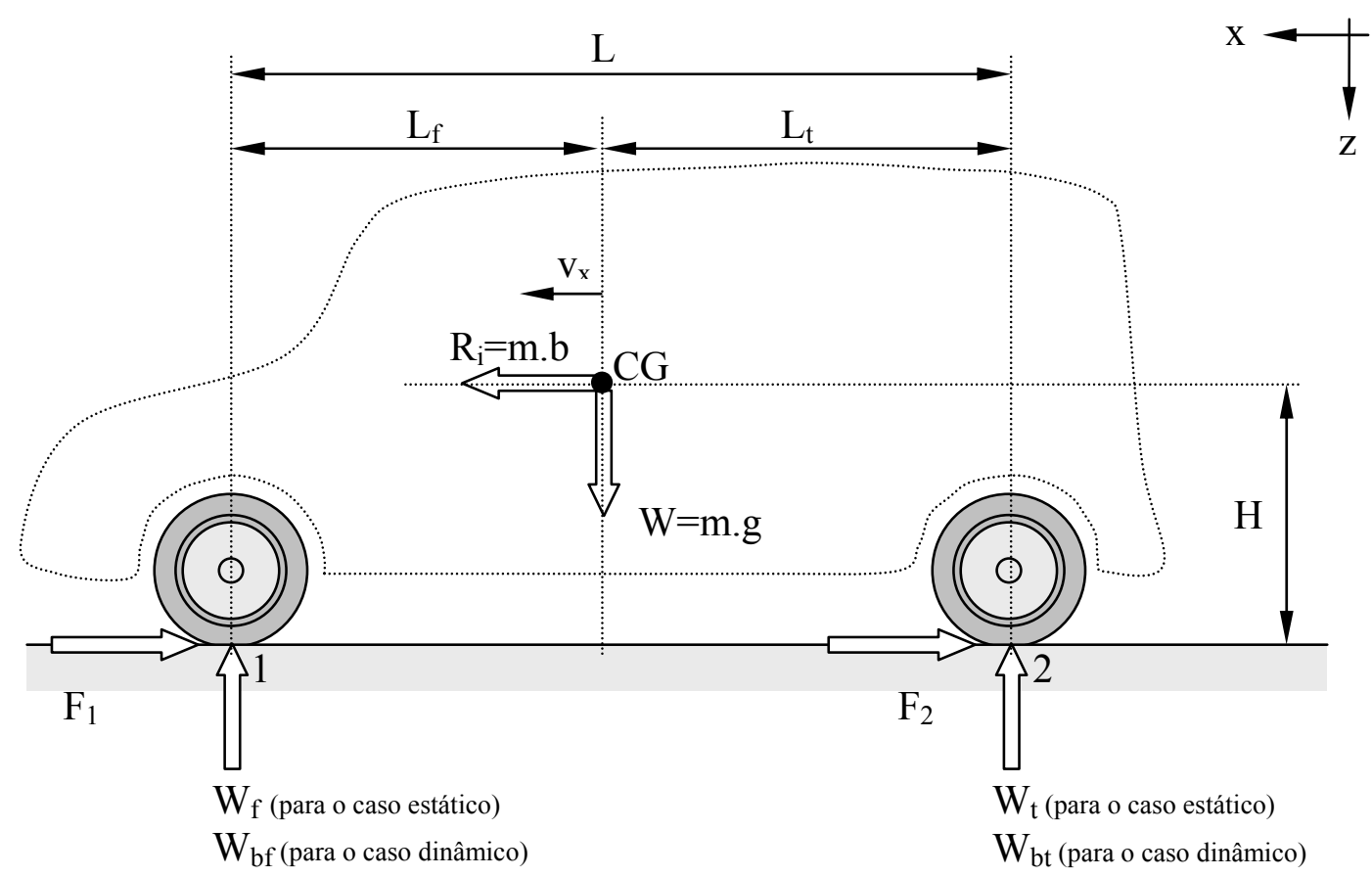

onde,

$\mathrm{R}_{\mathrm{i}}$ : é a resultante de inércia do movimento acelerado de translação;

$\mathrm{m}$ : a massa total do veículo;

$\mathrm{b}:$ desaceleração;

$\mathrm{g}:$ aceleração da gravidade;

$\mathrm{W}$ : força peso;

$\mathrm{W}_{\mathrm{f}}$ : peso estático sobre o eixo dianteiro;

$\mathrm{W}_{\mathrm{bf}}$ : o peso dinâmico sobre o eixo dianteiro;

$\mathrm{W}_{\mathrm{t}}$ : peso estático sobre o eixo traseiro;

$\mathrm{W}_{\mathrm{bt}}$ : o peso dinâmico sobre o eixo traseiro;

$\mathrm{F}_{1}$ : soma das forças de resistência impostas pelo solo à roda do eixo dianteiro;

$\mathrm{F}_{2}$ : soma das forças de resistência impostas pelo solo à roda do eixo traseiro.

Figura 2.40 - Sistema de forças atuantes numa frenagem em pavimento plano.

A figura 2.40 mostra as principais forças que atuam no veículo sob frenagem, num pavimento plano horizontal. Todas as forças que se opõe ao movimento do veículo, descritas anteriormente podem ser denominadas comumente de forças de frenagem $\left(\mathrm{F}_{1}\right.$ e $\left.\mathrm{F}_{2}\right)$, apesar de que as forças resistivas ao movimento não decorrentes da aplicação do freio do veículo representam em termos práticos, $1 \%$ da carga estática do eixo, caso este não proporcione a tração do veículo, e 1,5\% da carga estática do eixo, caso este proporcione a tração do veículo (Norma ABNT NBR 14353, 1999). Desta forma, seria razoável se 
considerar que a força de frenagem é praticamente oriunda da força aplicada pelo sistema de freio.

De acordo com Lucas (1995a), as forças normais dinâmicas $\left(\mathrm{W}_{\mathrm{bf}}\right)$ e $\left(\mathrm{W}_{\mathrm{bt}}\right)$ devido à força de frenagem, diferem das forças normais estáticas $\left(\mathrm{W}_{\mathrm{f}}\right)$ e $\left(\mathrm{W}_{\mathrm{t}}\right)$ devido ao efeito denominado "transferência dinâmica de carga", que é diretamente dependente da desaceleração do veículo (b) e da altura do centro de gravidade $(\mathrm{H})$. Assim, numa condição estática do veículo tem-se que:

$$
\begin{aligned}
& \sum \mathrm{M}_{\mathrm{l}_{\text {ESTÁATCO }}}=0 \\
& \mathrm{~W}_{\mathrm{t}}=\mathrm{W} \cdot \frac{\mathrm{L}_{\mathrm{f}}}{\mathrm{L}} \\
& \sum \mathrm{F}_{\mathrm{Z}_{\text {ESTÁATCO }}}=0 \\
& \mathrm{~W}_{\mathrm{f}}=\mathrm{W}\left(1-\frac{\mathrm{L}_{\mathrm{f}}}{\mathrm{L}}\right)
\end{aligned}
$$

Numa condição dinâmica devido à frenagem do veículo, surge à inércia $R_{i}$ decorrente da desaceleração do veículo, onde se tem:

$$
\begin{aligned}
& \sum \mathrm{M}_{\mathrm{1}_{\text {DINÂMICO }}}=0 \\
& \mathrm{~W}_{\mathrm{bt}}=\mathrm{W}_{\mathrm{t}}-\frac{\mathrm{mbH}}{\mathrm{L}} \\
& \sum \mathrm{F}_{\mathrm{z}_{\text {DINÂMICO }}}=0 \\
& \mathrm{~W}_{\mathrm{bf}}=\mathrm{W}_{\mathrm{f}}+\frac{\mathrm{mbH}}{\mathrm{L}}
\end{aligned}
$$

A norma brasileira NBR 14353 (1999) define o coeficiente de adesão como sendo o "quociente de força de frenagem máxima sem travamento das rodas e a carga 
dinâmica correspondente ao eixo que está sendo freado". Assim pode-se definir o coeficiente de adesão como:

$$
\mu_{\mathrm{HF}_{\mathrm{i}}}=\frac{\mathrm{F}_{\mathrm{x}_{\mathrm{i}}}}{\mathrm{W}_{\mathrm{b}_{\mathrm{i}}}}
$$

sendo que,

$\mathrm{F}_{\mathrm{x}_{\mathrm{i}}}:$ força de frenagem máxima atuante no pneu

$\mathrm{W}_{\mathrm{b}_{\mathrm{i}}}$ :força dinâmica normal aplicado no eixo

i: designação do eixo

Deste modo, numa condição ótima de frenagem (LIMPERT, 1999), considerase que a força de frenagem atuante no veículo seria:

$$
\mathrm{F}_{1}+\mathrm{F}_{2} \approx \mathrm{F}_{\mathrm{f}}+\mathrm{F}_{\mathrm{t}}=\mu_{\mathrm{HF}_{\mathrm{f}}} \cdot \mathrm{W}_{\mathrm{bf}}+\mu_{\mathrm{HF}_{\mathrm{t}}} \cdot \mathrm{W}_{\mathrm{bt}}=\mathrm{m} \cdot \mathrm{b}
$$

Considerando que num automóvel de passeio normalmente utiliza-se os mesmos pneus tanto no eixo dianteiro, quanto no eixo traseiro, pode-se considerar que:

$$
\mu_{\mathrm{HF}_{\mathrm{f}}}=\mu_{\mathrm{HF}_{\mathrm{t}}}=\mu_{\mathrm{HF}}
$$

Assim sendo, da equação 2.13 resulta que:

$$
\begin{gathered}
\mathrm{m} \cdot \mathrm{b}=\mu_{\mathrm{HF}} \cdot \mathrm{W}_{\mathrm{bf}}+\mu_{\mathrm{HF}} \cdot \mathrm{W}_{\mathrm{bt}}=\mu_{\mathrm{HF}} \cdot \mathrm{W}=\mu_{\mathrm{HF}} \cdot \mathrm{m} \cdot \mathrm{g} \\
\mu_{\mathrm{HF}}=\frac{\mathrm{b}}{\mathrm{g}}
\end{gathered}
$$

\subsubsection{Curva de distribuição de frenagem}

A curva de distribuição de frenagem mostrada na figura 2.41 representa a razão da força de frenagem em cada eixo pelo peso do veículo, onde temos a parcela representativa do eixo traseiro $\left(\mathrm{F}_{\mathrm{r}} / \mathrm{W}\right)$ nas ordenadas e a parcela representativa do eixo dianteiro $\left(\mathrm{F}_{\mathrm{f}} / \mathrm{W}\right)$ nas abscissas. 


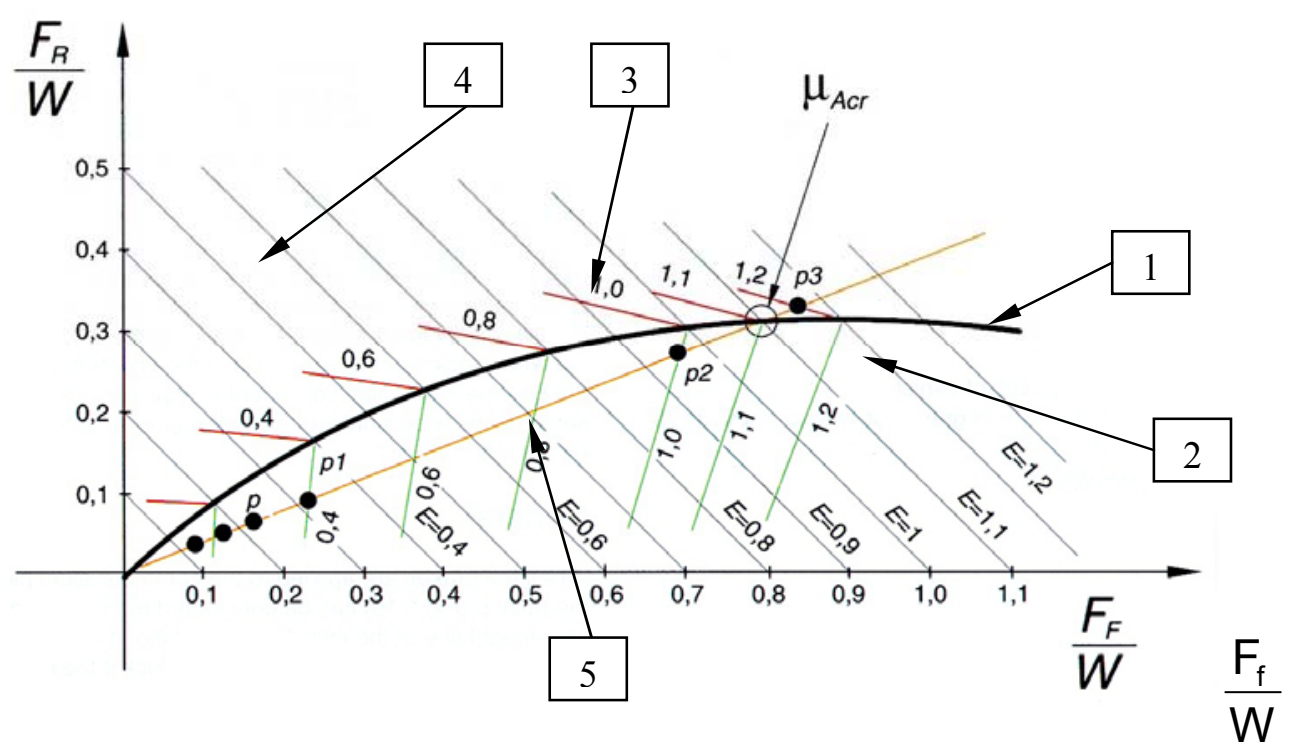

Figura 2.41 - Curva de distribuição de frenagem (LUCAS, 1995a).

A curva parabólica (Item 1, figura 2.41) representa a curva de força de frenagem ótima ou ideal, onde a máxima aderência é utilizada tanto pelo eixo dianteiro quanto pelo eixo traseiro. Esta curva é resultante do cruzamento das linhas de iso-aderência dianteiro (Item 2, figura 2.41) e traseiro (Item 3, figura 2.41).

As linhas inclinadas a $45^{\circ}$ (Item 4, figura 2.41) representam as linhas de eficiência de frenagem constante ou aderência constante (LUCAS, 1995a).

A reta inclinada que parte da origem representa a linha de distribuição instalada (Item 5, figura 2.41). O cruzamento da linha de distribuição instalada com a curva de distribuição ideal, determina o ponto conhecido como da aderência crítica $\left(\mu_{\mathrm{ACR}}\right)$, e representa a máxima desaceleração que o sistema de freio pode proporcionar ao veículo sem que o eixo traseiro apresente travamento antes do dianteiro. Deste modo, toda condição de projeto que leve o sistema de freio do veículo a operar em qualquer ponto acima da curva de distribuição ideal, como o ponto $\mathrm{P}_{3}$, conduz ao travamento do eixo traseiro antes do dianteiro, o que pode resultar numa condição de instabilidade de trajetória do veículo durante a frenagem (REIMPELL; STOLL; BETZLER, 2001). Já a condição de operação em qualquer ponto 
abaixo da curva ideal leva ao travamento do eixo dianteiro antes do traseiro, o que é preferível sob o ponto de vista da instabilidade de frenagem.

A curva da distribuição instalada representa aquilo que é possível obter com os componentes convencionais de freio, devido ao fato de reproduzir a conversão da pressão hidráulica no momento da frenagem proporcional a certas características ajustáveis no projeto do sistema de freio, tais como (LUCAS, 1995a):

- Área dos êmbolos dos freios a disco ou dos cilindros de roda que geram as forças atuantes nas pastilhas ou nas sapatas de freio;

- O coeficiente de atrito entre o material de atrito da pastilha ou lona e o disco ou o tambor de freio;

- Relação entre o raio efetivo de trabalho $\mathrm{r}_{\mathrm{f}}$ do disco ou do tambor, onde é aplicado o torque de frenagem e o raio dinâmico de rolamento do pneu $\mathrm{r}_{\mathrm{r}}$ (figura 2.42).

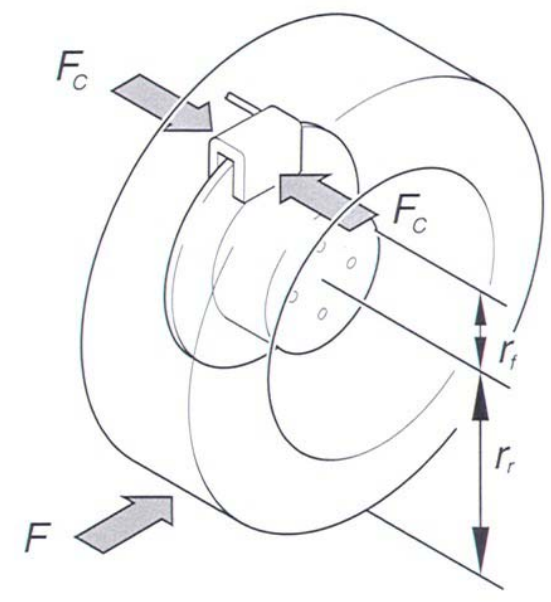

Figura 2.42 - Raio efetivo $r_{f}$ e raio dinâmico do pneu $r_{r}$ (LUCAS, 1995a).

Para um melhor aproveitamento da capacidade de frenagem conferida pelo nível de aderência disponível para um dado pavimento, é extremamente útil o emprego de dispositivos de controle de pressão, tais como válvulas de corte fixo, e preferencialmente as válvulas sensíveis à carga, como descritos anteriormente. Uma aproximação mais precisa da 
curva ideal de frenagem só pode ser obtida com a utilização de dispositivos de controle eletrônico, tais como ABS e EBD. 


\section{CONFORTO DE FRENAGEM}

\subsection{Introdução}

De um modo geral, pode-se definir o conforto de frenagem como a sensação que o motorista/usuário de um automóvel sente ao acionar o pedal de freio, durante o ato de desacelerar este veículo. Esta sensação ao acionar o pedal de freio, que se pode denominar como sensação de pedal de freio, possui não somente uma relação com o conforto do usuário, mas também a sensação de segurança que é transmitida ao motorista/usuário (AUGSBURG apud BREUER; DAUSEND, 2003).

A avaliação deste conforto de pedal tem sido realizada de uma maneira geral, através de opiniões subjetivas, tanto por parte da imprensa especializada como por parte da indústria montadora (EBERT; KAATZ, 1994). No caso da imprensa especializada, inclusive é muito mais comum à utilização de informações como distância de parada para caracterizar o desempenho de frenagem dos veículos, que representa na realidade, uma condição limite de uso do freio do veículo, mas não necessariamente representa as condições normais de uso dos motoristas na sua maior parte do tempo no trânsito, seja nas cidades ou mesmo nas estradas. As opiniões subjetivas, quando realmente utilizadas para avaliação do conforto utilizam termos adjetivos tais como "boa progressividade"1, "pedal esponjoso", "pedal leve"3, "pedal duro", , entre outros.

No caso da indústria montadora, os departamentos de Planejamento de Produto e de Marketing são os principais responsáveis na coleta de informações sobre os desejos e

\footnotetext{
${ }^{1}$ Progressividade refere-se à sensação de linearidade entre a modulação do pedal (aplicação do esforço/curso do pedal de freio) comparado à desaceleração percebida por parte do motorista.

${ }^{2}$ Considera-se "pedal esponjoso", a falta de definição do início da desaceleração do veículo durante a modulação do pedal de freio.

${ }^{3}$ Entende-se por "pedal leve" o sistema de freio que apresenta um rápido início de desaceleração no início da modulação do pedal de freio.

4 "Pedal duro" é a sensação na qual o motorista necessita aplicar grandes esforços para desacelerar o veículo, de modo que a participação da assistência de frenagem praticamente é nula.
} 
expectativas dos clientes, que na sua grande maioria, são expressas em termos vagos e subjetivos, não permitindo uma transformação direta dessas opiniões em parâmetros de projeto de sistemas de freio por parte do departamento de Engenharia do Produto. Expressões tais como "o carro deve parar rapidamente", "quando eu uso mais força, é que o carro deve parar mais rapidamente", "o freio deve atuar logo quando piso no pedal" são alguns dos exemplos de opiniões que se pode observar.

Segundo Kowalski e Ebert (1993), para que as informações subjetivas coletadas sejam realmente significativas e úteis para a definição dos parâmetros de projeto, podem ser realizadas clínicas com clientes potenciais do veículo-alvo, onde cada cliente é entrevistado por um profissional e acompanhado por um técnico, de modo que as informações necessárias sejam coletadas diretamente. Este método pode apresentar resultados possivelmente exatos e completos, desde que a amostragem de dados seja representativa do mercado alvo, mas demandam muito tempo e apresentam custos elevados na sua condução. Uma outra possibilidade seria a realização de pesquisas de campo, através de questionários a serem preenchidos pelos clientes potenciais ou através de entrevistas conduzidas por serviços de telemarketing, que podem apresentar um retrato da opinião dos clientes com exatidão, inferior ao primeiro método. Mesmo assim, os resultados obtidos não podem ser diretamente transformados em dados de engenharia.

Os exames de satisfação do comprador, tais como o realizado pela $J$. $D$. Powers $^{5}$ e relatórios do consumidor podem informar as preferências do consumidor, mas focalizam em problemas e/ou falhas presentes nos veículos que o cliente experimentou, não fornecendo muitos dados de entrada úteis a respeito da percepção da sensação do sistema de freio. Além disso, os dados aqui obtidos abordariam somente àquelas pessoas que compraram

\footnotetext{
5 J. D. Powers é empresa global de informação de marketing estabelecida em 1968, que conduz exames independentes e imparciais da satisfação do cliente, da qualidade de produto e do comportamento do comprador.
} 
o veículo, enquanto que os dos clientes potenciais que resolveram adquirir veículos concorrentes, não seriam abordados.

Os dados de garantia das montadoras podem possivelmente fornecer dados a cerca da satisfação com a sensação do freio, se o nível de descontentamento for bastante alto, mas geralmente fornecem poucas informações úteis sobre a satisfação do cliente com a sensação do pedal.

Outra fonte de opinião de conforto de frenagem dentro das montadoras são aquelas fornecidas por avaliadores da própria montadora através de avaliações subjetivas. Normalmente, estas avaliações subjetivas são executadas sob circunstâncias de operação controladas e tentam simular todas as condições de uso experimentadas pelos clientes. Os critérios de avaliação e a escala de pontuação, dirigidos para análise de sensação de freio, são estabelecidos entre outras análises subjetivas. A figura 3.1 apresenta um exemplo de escala de desempenho associada com uma avaliação numérica, onde o avaliador aplica a sua pesquisa sobre a avaliação à sensação subjetiva da manobra de frenagem (KOWALSKI; EBERT, 1993).

Este veículo atende a sua expectativa para parar rapidamente a $60 \mathrm{~km} / \mathrm{h}$ em uma linha reta? Circunde por favor, a avaliação apropriada.

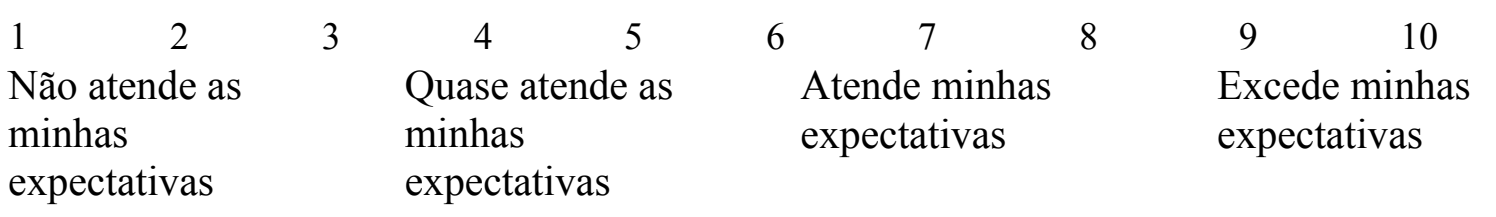

Figura 3.1 - Exemplo de um item de avaliação subjetiva realizada por montadoras (KOWALSKI; EBERT, 1993).

Entretanto, este fato faz com que os resultados dependam em grande parte pura e exclusivamente, da capacidade de sensibilidade do avaliador em transformar suas sensações em notas de pontuação, a qual pode ou não divergir dos resultados de outros avaliadores, dependendo não só do seu grau de aprimoramento e sensibilidade, como também pelo "gosto" 
particular de cada avaliador tem em relação ao item avaliado. Neste sentido, são necessários esforços significativos em treinamento de avaliadores, para que ser estabelecido certo padrão de avaliação subjetiva.

A utilização de critérios numéricos para análise de conforto de frenagem pode além de auxiliar e complementar a análise subjetiva, estabelecer o elo entre a sensação de frenagem avaliada e percebida com os parâmetros objetivos mensuráveis, que fazem parte da concepção técnica do projeto de sistemas de freio. Uma vez que estes critérios estejam bastante refinados, podem-se diminuir as variações de opiniões subjetivas resultantes do nível dos avaliadores, além de permitir uma análise prévia do que se pode ter como resultado do funcionamento do sistema de freio em sua fase inicial de projeto, antes mesmo de serem realizados os primeiros ensaios veiculares, reduzindo os riscos de re-projeto e seus custos.

\subsection{Análise Objetiva do Conforto de Frenagem}

Segundo Gillespie (1992), a importância da ergonomia no projeto de um sistema de freio de um veículo está no fato de permitir aos usuários usufruir toda a potencialidade de frenagem disponível de maneira otimizada. Além do posicionamento do pedal de acionamento do freio em relação a outros pedais, tais como o do acionamento do acelerador e do acionamento da embreagem, o esforço e o curso de pedal durante a frenagem são variáveis influentes no projeto do sistema.

A sensação do pedal de freio, portanto, descreve como o esforço de pedal, o curso de pedal e a desaceleração do veículo interagem em função do tempo (AUGSBURG apud BREUER; DAUSEND, 2003). O estabelecimento da correlação entre estas variáveis mensuráveis no veículo (esforço de pedal, curso de pedal e desaceleração) em função do tempo com as avaliações subjetivas resulta na análise objetiva do conforto de frenagem e 
define os limites de aceitação com o objetivo de estabelecer uma boa sensação de pedal de freio.

Mortimer et al. (1970) publicaram um trabalho, identificando para diversas condições de ganho de força de pedal - razão entre força de pedal e desaceleração - uma faixa ótima de conforto de pedal para homens e mulheres que potencializassem ao máximo a frenagem do veículo. A figura 3.2 apresenta os resultados obtidos e a faixa ótima de ganho de pedal.

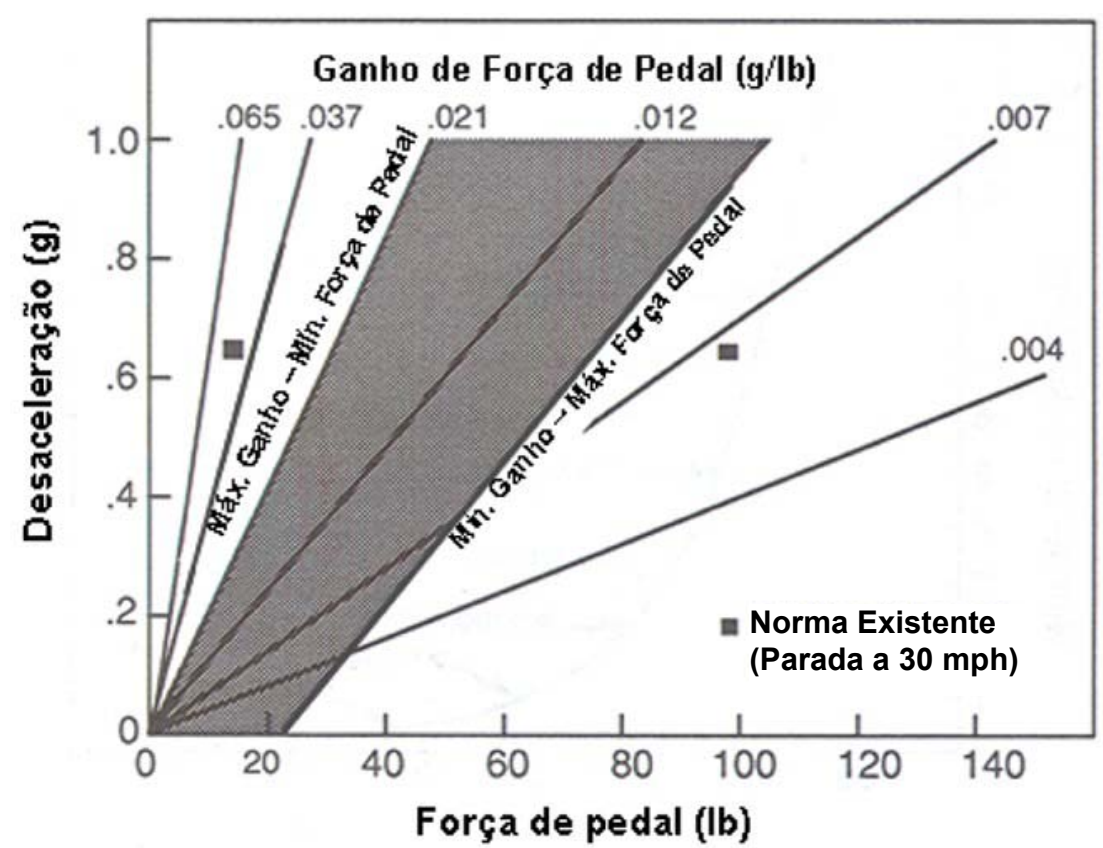

Figura 3.2 - Propriedades de ganho de força de pedal ótima (MORTIMER et al., 1970).

Este trabalho conclui que a força máxima exercida com o pé direito durante a frenagem por $5 \%$ da população feminina é de aproximadamente $378 \mathrm{~N}$ (85 lbf), apesar de Limpert (1999) observar que a força máxima exercida poderia ser de $445 \mathrm{~N}$ (100 lbf) para o mesmo percentual da população feminina e aproximadamente $823 \mathrm{~N}(185 \mathrm{lbf})$ para a população masculina. Vale ressaltar que a regulamentação européia ECE - R13 estabelece como limite de força de pedal de freio $500 \mathrm{~N}$ para automóveis de passeio (categoria M1). Ainda segundo Limpert (1999), considera-se também que veículos que normalmente utilizam 
servo-freio com assistência a vácuo, a força de pedal máxima de aproximadamente $223 \mathrm{~N}$ a $489 \mathrm{~N}$ (50 lbf a $75 \mathrm{lbf}$ ) deve fornecer uma desaceleração de $0,9 \mathrm{~g}$ a 1,0 g. O curso de pedal associado a esta condição de força de pedal não deve ultrapassar de $75 \mathrm{~mm}$ a $90 \mathrm{~mm}$ para freios na condição "fria" (temperatura do freio menor que $90{ }^{\circ} \mathrm{C}$ ).

Uma abordagem mais completa, porém, simplificada foi apresentada por Kowalski e Ebert (1993), que correlacionou as medidas objetivas de frenagem tais como força de pedal, curso de pedal e tempo de resposta do sistema de freio com as avaliações subjetivas através de um indicador numérico, o Índice de Sensação de Freio ou Brake Feel Index (BFI). Este indicador numérico é baseado num sistema de pontuação de até 100 pontos. A figura 3.3 apresenta um exemplo de cálculo do BFI para um veículo em particular.

\begin{tabular}{|l|c|c|l|}
\hline \multicolumn{1}{|c|}{ PARÂMETRO } & PESO & OBJETIVO & \multicolumn{1}{|c|}{ MÉTODO DE CÁCCULO } \\
\hline $\begin{array}{l}\text { Força da pré-carga do } \\
\text { pedal }\end{array}$ & $5 \%$ & - & $\begin{array}{l}\text { Subtraia 1 \% para cada 4,4 N (1 lbf) sobre } \\
\text { o valor objetivo }\end{array}$ \\
\hline $\begin{array}{l}\text { Força de pedal em baixa } \\
\text { desaceleração }\end{array}$ & $5 \%$ & - & $\begin{array}{l}\text { Subtraia 1\% para cada 4,4 N (1 lbf) sobre } \\
\text { o valor objetivo }\end{array}$ \\
\hline $\begin{array}{l}\text { Curso de pedal em baixa } \\
\text { desaceleração }\end{array}$ & $20 \%$ & - & $\begin{array}{l}\text { Subtraia 2 \% para cada 25 mm (1 pol.) } \\
\text { excedente do valor objetivo }\end{array}$ \\
\hline $\begin{array}{l}\text { Força do pedal em } \\
\text { desaceleração moderada }\end{array}$ & $10 \%$ & - & $\begin{array}{l}\text { Subtraia 1\% para cada 4,4 N (1 lbf) sobre } \\
\text { o valor objetivo }\end{array}$ \\
\hline $\begin{array}{l}\text { Curso de pedal em } \\
\text { desaceleração moderada }\end{array}$ & $10 \%$ & - & $\begin{array}{l}\text { Subtraia 1\% para cada 50 mm (2 pol.) } \\
\text { acima do objetivo, ou subtraia 1 \% para } \\
\text { cada 25 mm (1 pol.) abaixo do objetivo. }\end{array}$ \\
\hline $\begin{array}{l}\text { Força de pedal em } \\
\text { desaceleração elevada }\end{array}$ & $20 \%$ & - & $\begin{array}{l}\text { Subtraia 1\% para cada 4,4 N (1 lbf) sobre } \\
\text { o valor objetivo }\end{array}$ \\
\hline Tempo de resposta & $30 \%$ & - & $\begin{array}{l}\text { Subtraia 1,5\% para cada 1 s excedente ao } \\
\text { tempo objetivo }\end{array}$ \\
\hline Contagem máxima & $100 \%$ & \multicolumn{2}{|l}{} \\
\hline
\end{tabular}

\section{Figura 3.3 - Método de Cálculo do Índice de Sensação de Frenagem (BFI) (KOWALSKI; EBERT, 1993).}

Para o desenvolvimento do BFI, aproximações empíricas foram feitas, pesos e métodos de cálculos foram ajustados até que a correlação entre os dados objetivos e subjetivos existentes fosse atingida. Foram estabelecidas para o levantamento dos dados objetivos as seguintes características dos veículos: velocidade do veículo, condição do freio 
(por exemplo, pré-assentado, assentado ou pós-fade), temperatura inicial de frenagem, condição de pista de teste, nível de vácuo no servo-freio, carregamento do veículo (condição vazia, meia-carga ou carregado), velocidade de aplicação da força no pedal.

A utilização do BFI, entretanto não substitui o uso de medições objetivas detalhadas do desempenho do sistema de freio. Esta condição de correlação entre dados objetivos e subjetivos permite prognosticar razoavelmente a sensação subjetiva de um freio, mesmo que o veículo em questão ainda esteja em fase de projeto. Análises realizadas em vários veículos de diversas categorias mostram uma correlação boa entre o BFI e as avaliações subjetivas efetuadas (Coeficiente de Correlação ${ }^{6} \mathrm{R}^{2}>0,79$ ). Valores de Coeficiente de Correlação entre 0,40 e 0,70 são considerados razoáveis.

Em seu trabalho, Pascali et al. (2003) desenvolveu um novo processo para traduzir a sensação de frenagem em valores mensuráveis e prognosticáveis através de índices de qualidade (Q.I.), para então gerar especificações de sistemas de freio. O estabelecimento destes índices de qualidade é realizado através do desdobramento da qualidade da sensação de freio, que analisa as seguintes funções: eficiência global da frenagem, controlabilidade (capacidade de modulação) da frenagem, progressividade do pedal, sensação da força do pedal, sensação do curso de pedal e a esponjosidade do pedal (resposta do pedal do freio devido à deformação elástica dos componentes). A obtenção destes índices é realizada através de medições das variáveis correlacionadas às funções, comparadas a uma referência. Estes índices de qualidade, por sua vez, são utilizados para estabelecer o Índice Global da Sensação de Freio, denominado IQF. A aplicação da metodologia do IQF pode ser resumida em duas tarefas basicamente: a caracterização experimental do veículo-objeto de análise, que permite construir uma base de dados para o desdobramento objetivo do sistema de freio, onde através

\footnotetext{
${ }^{6}$ Coeficiente de Correlação $\mathrm{R}^{2}$ representa, no caso em questão, o percentual que uma mudança na avaliação subjetiva pode ser explicada por mudanças nas encontradas na medição objetiva.
} 
dos dados gerados, objetivos para o desempenho do sistema de freio são ajustados, e através de modelos de simulação numérica, permite a realização de ajustes de subsistemas.

Markus (1999) publicou um artigo sobre a influência dos tipos de freio de roda utilizados na sensação de frenagem. Foi observado que veículos com freio a disco nas quatro rodas podem oferecer uma sensação de pedal de freio melhor do que veículos de mesma plataforma, mas equipados com freio a tambor traseiro, devido à existência de perdas préoperativas no freio a tambor (pressões iniciais de trabalho típicas de 3,8 bar a 4,1 bar contra pressões típicas de 0,3 bar a 0,6 bar nos freios a disco), o que resulta em força e cursos de pedal maiores. Este fato permite que veículos com freio a disco nas quatro rodas apresentem respostas de frenagem mais rápidas e melhor progressividade que os veículos com freio a tambor no eixo traseiro. Esta diferença no desempenho dos componentes de freio torna praticamente impossível à utilização de servos-freios comuns às duas aplicações.

Ainda segundo Markus (1999), o tipo de freio a disco, a sua rigidez e o material de atrito utilizado, embora secundário, podem afetar também a sensação de pedal. Os freios a disco deslizantes, normalmente utilizados na maioria dos automóveis de passeio, têm possibilidade de se deformarem sob frenagem pesada, confundindo a sensação transmitida através do pedal de freio. Os freios a disco fixo por serem mais rígidos, geralmente apresentam sensações melhores de pedal de freio (KAKIHARA; MATSUZAKI apud BREUER, 2003).

Basch et al. (2002) analisaram a influência das propriedades dos materiais de atrito, representado pelas pastilhas e lonas de freio, com relação à sensação do pedal de freio. Características como o nível de fricção, taxa de crescimento do nível de atrito no momento da parada, a compressibilidade a frio e a compressibilidade a quente são algumas das propriedades dos materiais de fricção que podem influenciar a sensação do pedal. Apesar da sua influência na sensação de conforto de frenagem ser menor, comparado ao ajuste do servo- 
freio e dimensionamento dos componentes hidráulicos, a sua alteração é relativamente simples e apresentam impactos de custo relativamente baixos para sua implementação. Entretanto, considerando materiais de atrito com níveis de fricção de mesmo nível, de modo que não seja afetado o comportamento de frenagem do veículo, as diferenças em propriedades tais compressibilidade a frio e a quente, taxa de crescimento do nível de atrito no momento da parada mostraram-se muito sutis, mas perceptíveis quando analisadas do ponto de vista objetivo, no entanto, não apresentaram nenhuma diferença estatisticamente significativa do ponto de vista da avaliação subjetiva. 


\section{METODOLOGIA}

Para analisar o conforto de frenagem de um automóvel de passeio, o objetivo deste trabalho é realizar comparações entre as avaliações subjetivas de sensação de frenagem e as avaliações objetivas baseadas em resultados obtidos através da modelagem matemática do sistema de freio, utilizando um programa baseado em planilha de cálculo, para um estudo de caso envolvendo a mudança do material de atrito da pastilha do freio dianteiro.

A motivação da mudança do material de atrito da pastilha neste estudo de caso tem como objetivo, primeiramente a nacionalização do material de atrito buscando ganhos em termos de redução de custo do produto e em segundo lugar, a melhoria no desempenho de sua durabilidade em campo. Considerando que a sua aplicação deveria ser realizada num sistema de freio de um automóvel em produção, um terceiro objetivo consiste em proporcionar diferenças mínimas no desempenho e no conforto de frenagem do veículo, preservando deste modo a total intercambiabilidade entre os dois materiais de atrito.

Os trabalhos para seleção de materiais de atrito foram iniciados em conjunto com o fornecedor do sistema de freios, com o estudo de quatro propostas de materiais de atrito, sendo duas de fornecedores de materiais de atrito locais e, duas alternativas de fornecedores japoneses, sugeridas pela matriz da Montadora B. Para a seleção final, foram levados em consideração, além do atendimento dos objetivos acima mencionados, um bom desempenho em termos de conforto acústico ao motorista com relação aos ruídos de freio.

\subsection{Avaliação Subjetiva}

A avaliação subjetiva foi conduzida através de ensaios realizados com funcionários de vários departamentos, entre os quais, Engenharia de Produto, Qualidade, Assistência Técnica, Qualidade Assegurada, em veículos monitores da frota dos departamentos respectivos e em veículos pertencentes à gerência das áreas envolvidas, onde a 
pastilha de freio original fora substituída pela nova proposta de pastilha de freio. Todas as pessoas que participaram desta avaliação subjetiva tinham um longo contato com o veículo e com o sistema de freio utilizando a pastilha de freio original, o que tornaria possível a obtenção de resultados mais significativos do ponto de vista de qualquer alteração expressiva em termos do conforto de pedal.

Os trajetos utilizados para a realização desta avaliação subjetiva foram os mais diversos, sempre baseados na utilização dos veículos desde o transporte diário até o local de trabalho, como para viagens a trabalho, que resultam em trechos mistos de tráfego urbano e rodoviário, com participações percentuais variadas.

Para a realização da análise subjetiva de sensação de frenagem, foi utilizado um questionário baseado no procedimento de avaliação subjetiva comparativa entre o veículo com a pastilha original e o veículo com a pastilha proposta, utilizada pela Montadora B, denominada "Vehicle Screening Test", na qual quesitos relacionados ao sistema de freio são avaliados e recebem notas, que variam de 1,0 a 5,0, baseados em critérios de pontuação. A tabela 4.1 mostra os itens avaliados em termos de conforto de frenagem e a tabela 4.2 mostra os critérios de pontuação utilizados nesta avaliação, apesar da avaliação subjetiva realizada ter sido concentrada apenas no quesito sensação de freio, vibração e ruído. 
Tabela 4.1 - Avaliação Subjetiva: Itens relacionados ao conforto de frenagem.

\begin{tabular}{|l|}
\hline \multicolumn{1}{|c|}{ Itens de Avaliação } \\
\hline $\begin{array}{l}\text { Sensação de Freio } \\
\text { (Eficiência, Esforço de Pedal, Curso de Pedal, Balanceamento do Sistema, } \\
\text { Controle) }\end{array}$ \\
\hline Vibração \\
\hline Ruído \\
\hline $\begin{array}{l}\text { Estabilidade de frenagem em linha reta } \\
\text { (Desvio de trajetória, Puxada lateral) }\end{array}$ \\
\hline $\begin{array}{l}\text { Desempenho do ABS } \\
\text { (Ponto de acionamento, Ruído de Funcionamento, Estabilidade, } \\
\text { Controlabilidade da Direção) }\end{array}$ \\
\hline $\begin{array}{l}\text { Eficiência do Freio de Estacionamento } \\
\text { (\& acionamento acidental) }\end{array}$ \\
\hline $\begin{array}{l}\text { Desempenho do Servo-freio } \\
\text { (Capacidade/Recuperação de vácuo, Ruído de Funcionamento) }\end{array}$ \\
\hline Outros \\
\hline
\end{tabular}

Tabela 4.2 - Definição dos Critérios de Pontuação para o "Vehicle Screening Test".

\begin{tabular}{|c|l|}
\hline Notas & \multicolumn{1}{|c|}{ Definição } \\
\hline \hline 5 & $\begin{array}{l}\text { Muito melhor que os competidores. (O melhor de todos os } \\
\text { competidores.) }\end{array}$ \\
\hline 4 & Melhor que os competidores. \\
\hline 3,5 & Marginalmente melhor que a média dos competidores. \\
\hline 3,25 & Um pouco melhor que a média dos competidores. \\
\hline 3 & Nível médio entre os competidores. \\
\hline 2,75 & Um pouco abaixo que a média dos competidores. \\
\hline 2,5 & Marginalmente pior que os competidores. \\
\hline 2 & Pior que os competidores. \\
\hline 1 & Muito pior que os competidores. \\
\hline
\end{tabular}

\subsection{Avaliação Objetiva}

A análise objetiva do conforto de frenagem foi realizada através da simulação matemática do sistema de freio do veículo objeto de estudo, utilizando um programa computacional baseado em planilhas de cálculo Microsoft Excel $^{7}$ desenvolvido pela

\footnotetext{
${ }^{7}$ Microsoft Excel é marca registrada da Microsoft Corporation, Estados Unidos.
} 
Montadora B. Este programa leva em consideração apenas os efeitos da atuação do sistema de freio na desaceleração do veículo, desprezando o efeito das forças resistivas relativas à resistência ao rolamento, à resistência aerodinâmica, à resistência ao aclive e à resistência de inércia das partes rotativas do veículo, como a maior parte dos programas de cálculos de sistema de freio utilizados pelos fabricantes de sistemas de freio, tais como TRW Automotive e Robert Bosch. Foram comparados os resultados obtidos na modelagem matemática com critérios de aceitação de conforto de frenagem das Montadoras A e B.

Além da hipótese simplificadora acima mencionada, outras hipóteses simplificadoras são consideradas pelo programa de cálculo, a saber:

- Incompressibilidade do fluido de freio utilizado no veículo, apesar de Limpert (1999) apresentar uma forma de cálculo para determinação da perda de volume devido à compressão do fluido de freio;

- Desprezadas as perdas de volume decorrente da aplicação de pressão no sistema de freio, devido expansão volumétrica dos tubos de freio e no cilindro mestre, a existência de ar ou gás remanescente após a sangria do sistema de freio, e uma pequena parcela da compressibilidade do fluido de freio, apesar de Limpert (1999) apresentar uma forma de cálculo baseado em dados experimentais para a determinação destas perdas. Deste modo, apenas o cilindro mestre, as mangueiras flexíveis e os conjuntos de freio de roda contribuem para a absorção volumétrica do sistema de freio, afetando assim as variáveis: curso de pedal e força de pedal;

Neste programa, além da realização de cálculos básicos de balanceamento de frenagem e desempenho de frenagem, comparado aos requisitos das normas regulamentadoras, tais como a regulamentação européia ECE-R13, realiza também os cálculos relativos às variáveis relacionadas ao conforto de frenagem, tais como curso de pedal de freio, esforço de pedal de freio e desaceleração do veículo. Para realização destes cálculos 
do sistema de freio, além dos dados geométricos de instalação e especificação dos componentes de freio, foram levantados dados experimentais através de equipamentos de ensaio em bancada e dinamômetros de inércia nos laboratórios de ensaio do fabricante do sistema de freio e dos fabricantes de materiais de atrito. Estes dados obtidos permitiram também, numa primeira análise, avaliar o desempenho comparativo entre a pastilha original e pastilha proposta pelo fornecedor local.

Para o fabricante do sistema de freio foi solicitado o levantamento da absorção volumétrica do freio a disco dianteiro com a pastilha proposta comparada à pastilha original, a qual tem como objetivo medir o volume de fluido de freio consumido pelo conjunto de freio a disco em função da pressão hidráulica aplicada. A figura 4.1 ilustra o tipo de equipamento utilizado para medição da absorção volumétrica dos conjuntos freios a disco. Os resultados obtidos neste ensaio levam em consideração as deformações sofridas pelo freio a disco e a compressão da pastilha de freio devido à aplicação da pressão hidráulica. Segundo Schwanke (2002), a absorção volumétrica de um freio a disco é não linear.

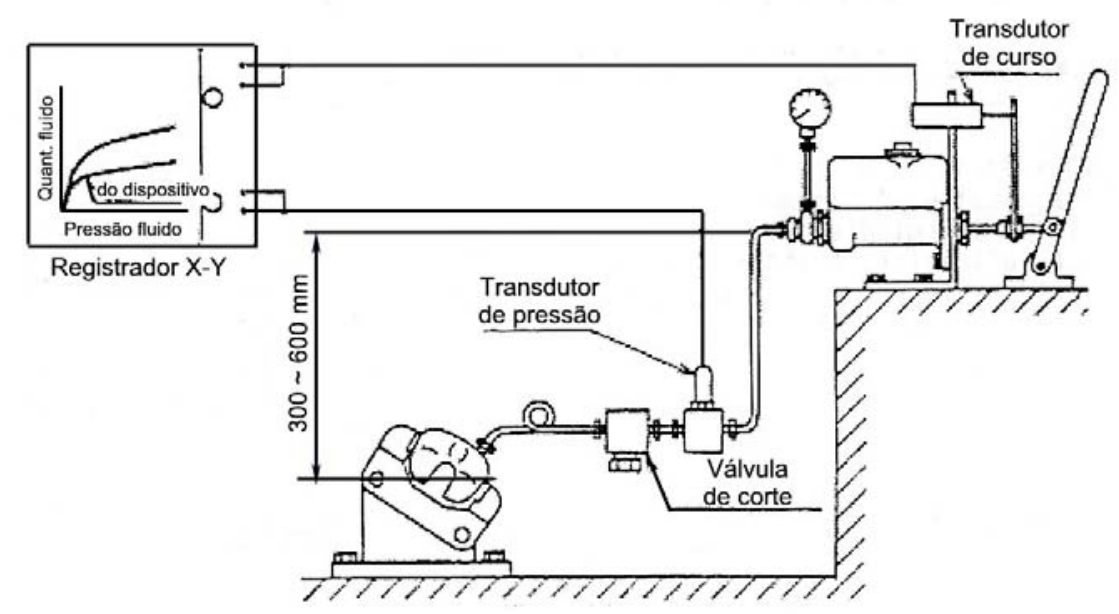

Figura 4.1 - Dispositivo para medição da absorção volumétrica.

No caso do fabricante de material de atrito, foram realizados ensaios comparativos entre a pastilha original e a pastilha proposta, considerando não somente o desempenho dinâmico necessário, através do levantamento do coeficiente de atrito da 
pastilha, mas também outras características importantes, como a compressibilidade da pastilha a frio e a quente, e o desempenho de ruído.

O levantamento do coeficiente de atrito da pastilha foi realizado baseado na norma AK Master Dynamometer Program Test (1998), a qual utiliza dinamômetros de inércia automotivos (figura 4.2), onde a inércia do veículo é simulada através de discos de inércia anexados ao eixo motor do dinamômetro, e por conseqüência, ao disco de freio. Para este ensaio, frenagens são aplicadas sob certas condições de velocidade, desaceleração e temperatura, obtendo-se valores de torque de frenagem, de onde são calculados e obtidos os valores de coeficiente de atrito.

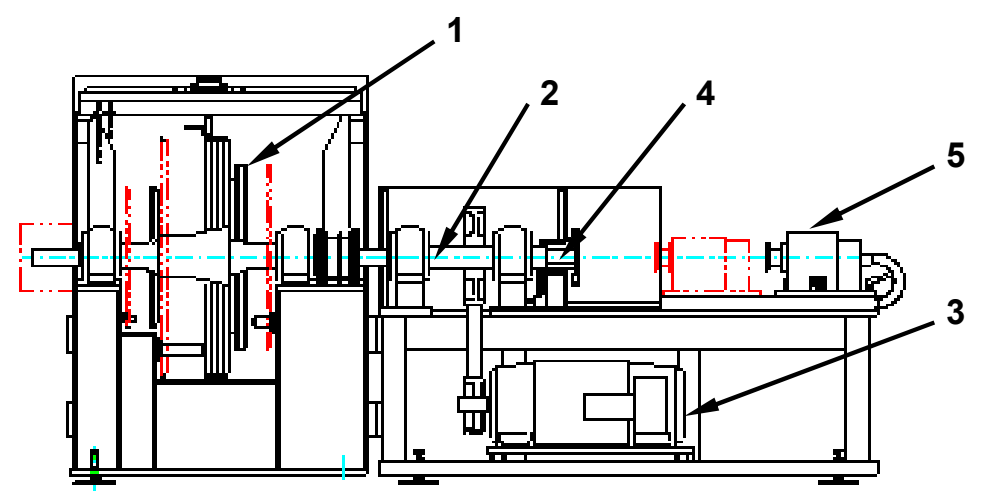

(1) discos de inércia; (2) eixo motor; (3) motor elétrico; (4) flange para o disco de freio; (5) suporte para o freio a disco;

Figura 4.2 - Esquema de um dinamômetro de inércia automotivo (LINK, 2005).

A medição da compressibilidade da pastilha a frio e a quente foi executada conforme os procedimentos descritos na norma TRW TS 6-11-101 (1997), que emprega um dispositivo de medição da compressibilidade em bancada (figura 4.3) e, mediante a aplicação e liberação cíclica de pressão sobre a pastilha, utilizando-se um corpo cilíndrico que tem a mesma função do êmbolo de um freio a disco, é medido o valor da sua deformação. Resistências elétricas contidos no dispositivo permitem o uso do mesmo tanto para medições a frio como para as medições a quente. 


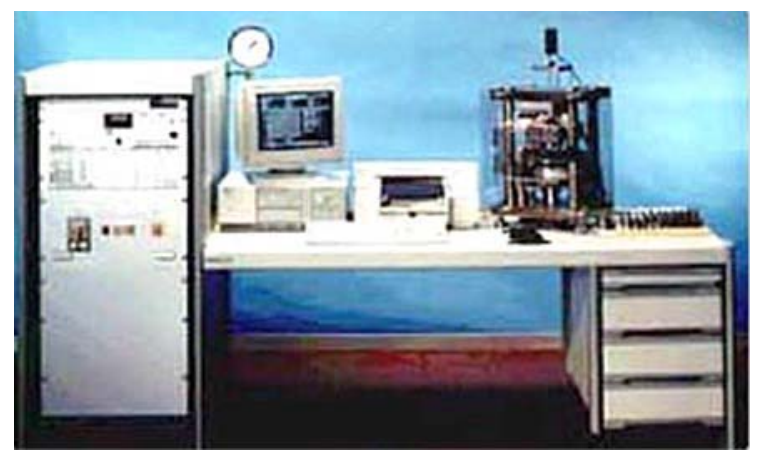

Figura 4.3 - Dispositivo de medição da compressibilidade da pastilha (Jurid, 2005).

Quanto ao desempenho da pastilha em relação ao conforto acústico, foi utilizada a norma AK Noise Test Procedure (1999), que realiza a avaliação empregando dinamômetros de inércia para análise de ruídos e vibrações, o qual se constitui de um dinamômetro de inércia com isolação acústica com dispositivo de coleta de ruído através de microfones. O sistema de freio é avaliado em conjunto com os demais componentes da suspensão, conforme a figura 4.4 .

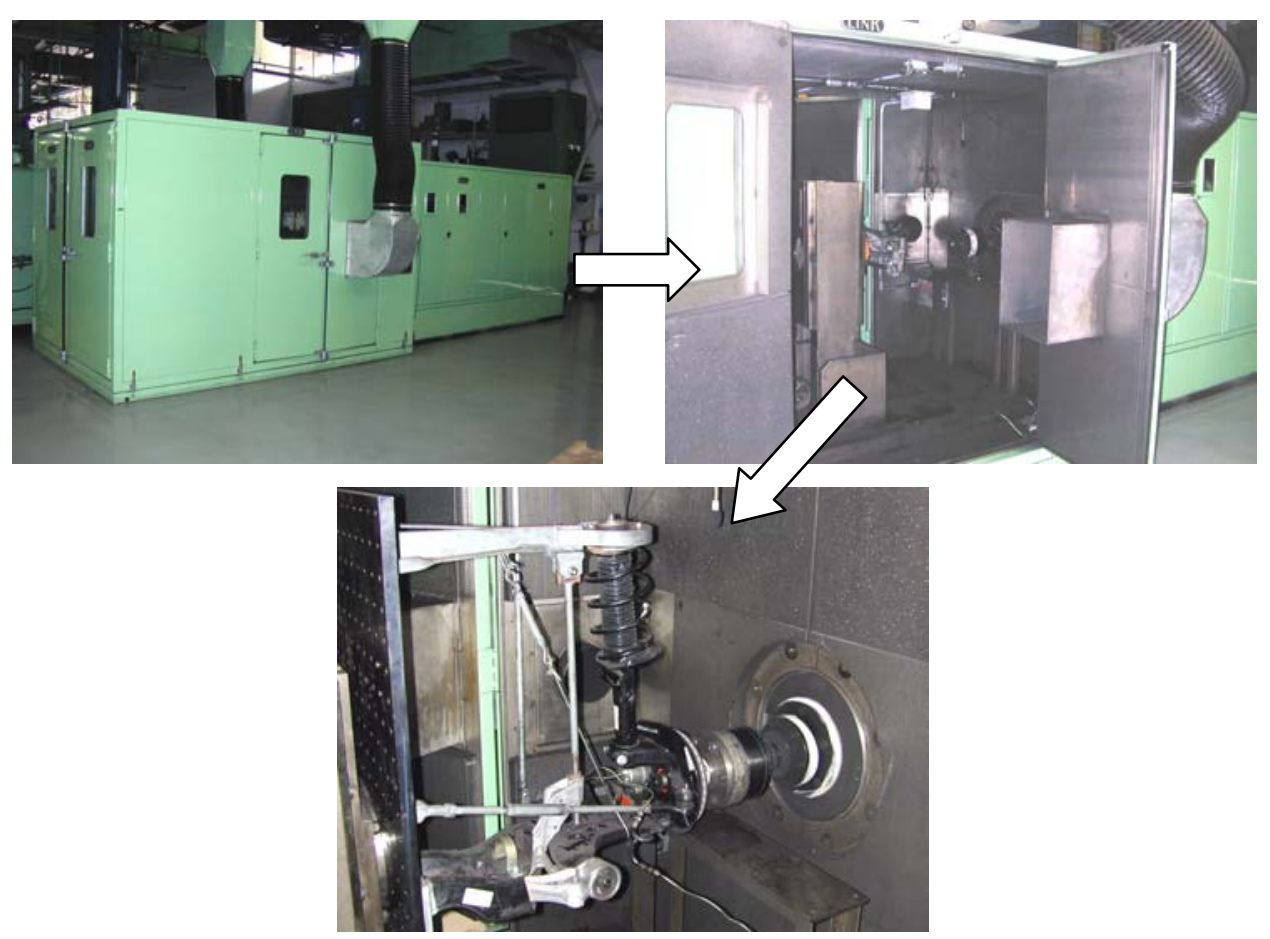

Figura 4.4 - Dinamômetro de inércia para análise de ruídos e vibrações (FRAS-LE, 2004). 
Além dos ensaios acima envolvendo o material de atrito, foi conduzido para fins de validação dos resultados de conforto de ruído, um ensaio em dinamômetro de chassis (figura 4.5), conforme procedimento baseada em norma da Montadora B, onde é realizada a medição de ruído de frenagem através do ensaio de um veículo completo numa câmara com isolação acústica e térmica.

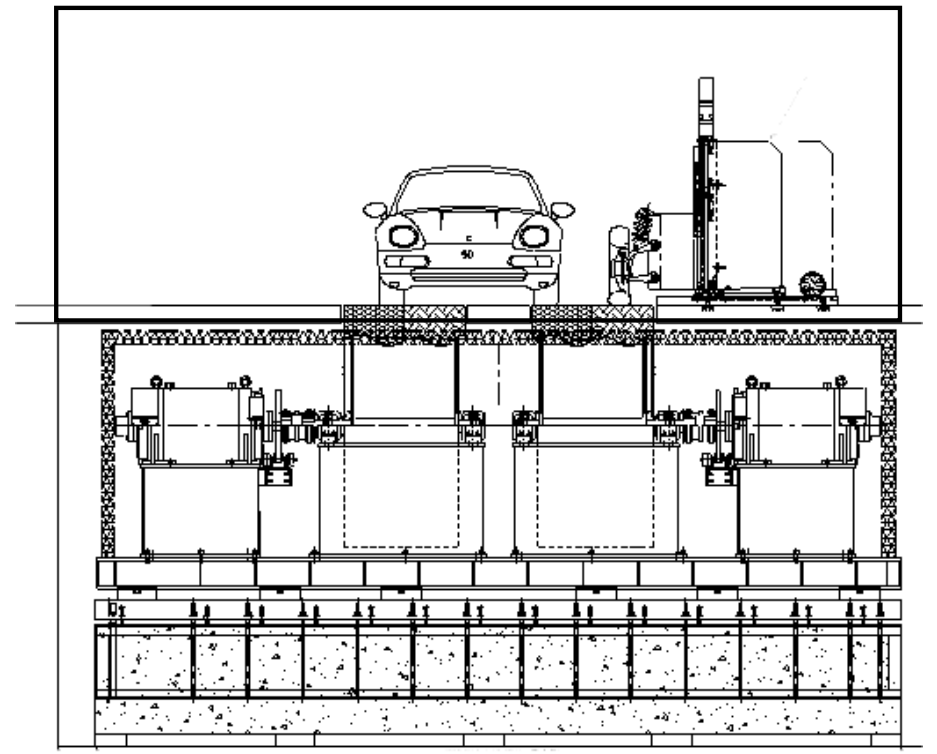

Figura 4.5 - Esquema de um dinamômetro de chassis (LINK, 2005).

A figura 4.6 mostra o fluxograma do programa de simulação utilizado e a figura 4.7 mostra a tela com os dados de entrada do programa de cálculo do sistema de freio utilizado. 


\section{Dados de entrada:}

1 - Dados do veículo: peso, distância entre eixos, massa por eixo, altura do CG, dimensões dos pneus;

2 - Dados do sistema de freio e dos componentes do freio, tais como raio efetivo, dia. êmbolos, fator de freio, etc.

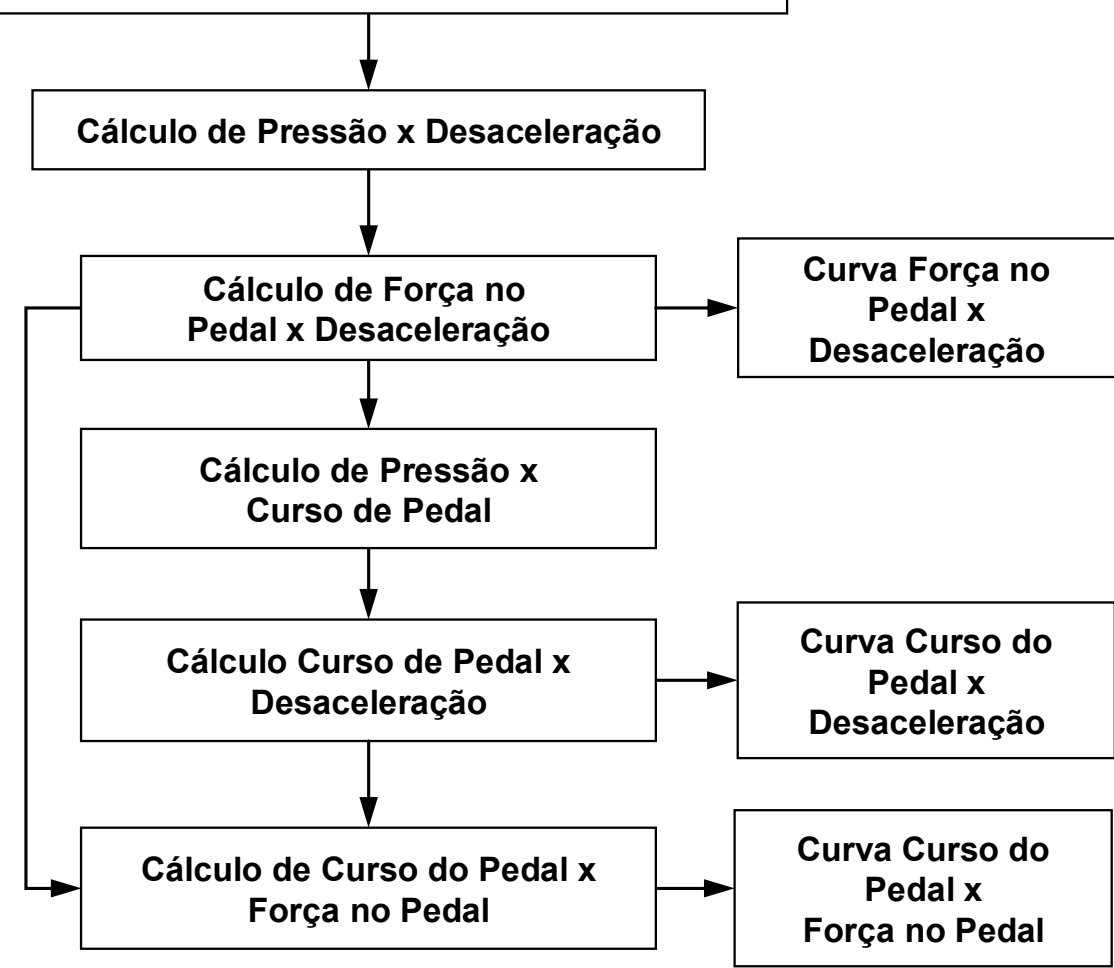

Figura 4.6 - Fluxograma do programa de simulação matemática para análise objetiva de conforto de frenagem. 

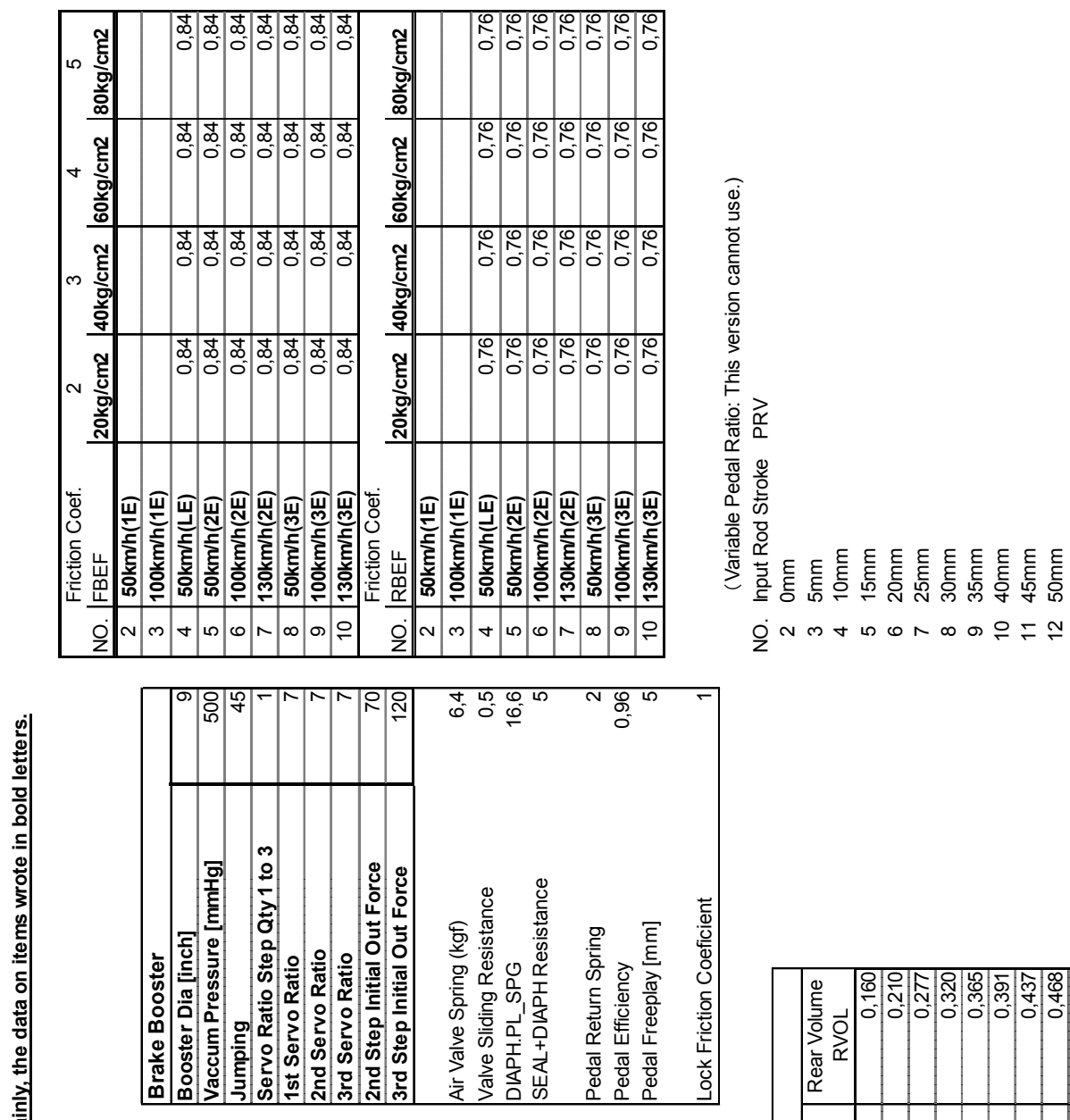

产.
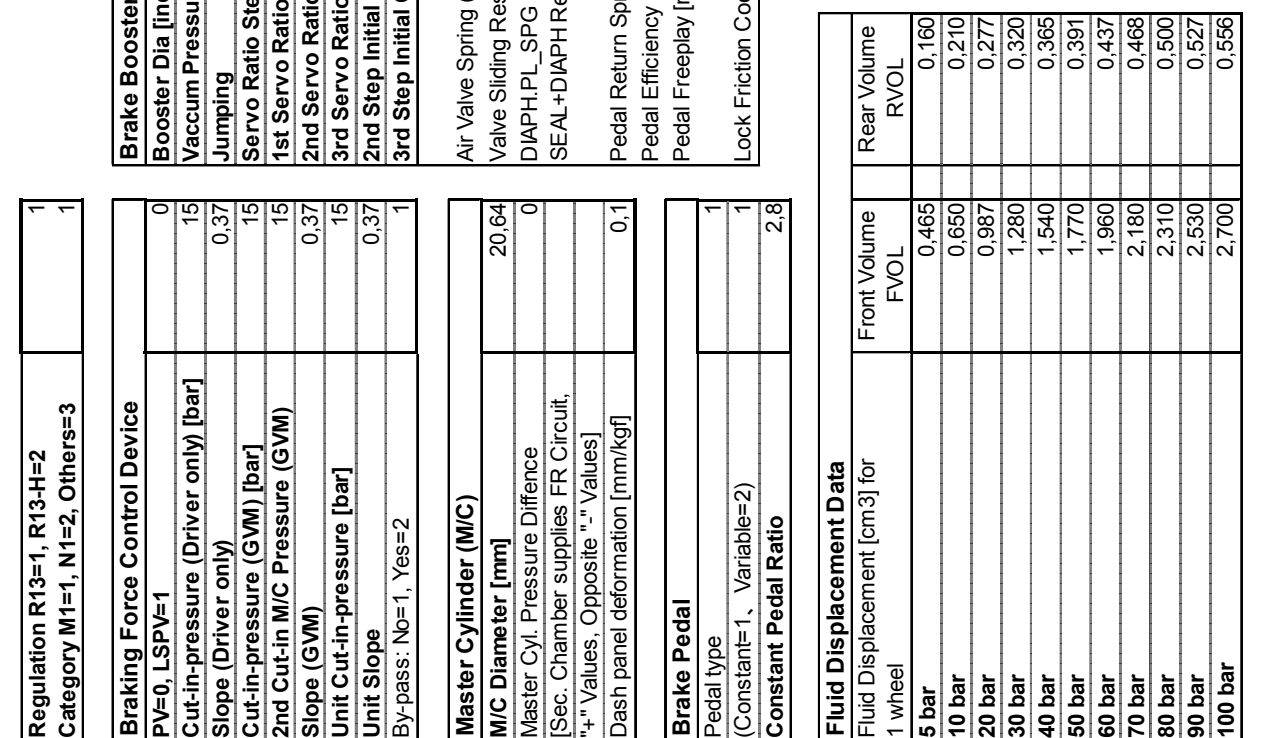

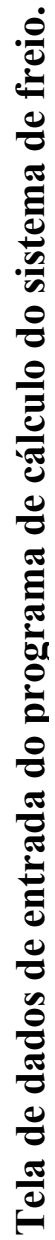


تัن 
Complementando a análise objetiva do sistema de freio, foram comparados os resultados obtidos pela simulação matemática com os critérios de aceitação utilizados pela Montadora B para que um veículo apresente um bom nível de conforto de frenagem.

Ainda no caso do veículo com a pastilha proposta, realizaram-se também medições experimentais no veículo através da utilização de equipamento de coleta de dados digital, onde os sinais foram adquiridos com uma taxa de amostragem de $1 \mathrm{kHz}$. Este ensaio foi realizado na pista de teste do fornecedor do sistema de freio, num dia com boas condições meteorológicas, sem chuva.

\subsection{Modelagem dinâmica da frenagem em linha reta}

Conforme comentado no capítulo anterior, o modelo matemático utilizado no programa de cálculo considerou somente as forças efetivas resultantes da aplicação do freio no veículo, desprezando as demais forças resistivas que de certa forma, contribuiriam a favor da força de frenagem, desacelerando o veículo.

Desta forma, para o cálculo da força de frenagem em cada eixo, têm-se as seguintes equações:

$$
\begin{aligned}
& \mathrm{F}_{\mathrm{f}}=2 \cdot\left(\mathrm{p}_{1}-\mathrm{p}_{\mathrm{o}}\right) \cdot \mathrm{A}_{\mathrm{WC}} \cdot \eta_{\mathrm{Cf}} \cdot \mathrm{BF}_{\mathrm{f}}\left(\frac{\mathrm{r}_{\mathrm{ef}}}{\mathrm{R}_{\mathrm{D}}}\right) \\
& \mathrm{F}_{\mathrm{t}}=2 \cdot\left(\mathrm{p}_{1}-\mathrm{p}_{\mathrm{o}}\right) \cdot \mathrm{A}_{\mathrm{WC}} \cdot \eta_{\mathrm{Ct}} \cdot \mathrm{BF}_{\mathrm{t}}\left(\frac{\mathrm{r}_{\mathrm{et}}}{\mathrm{R}_{\mathrm{D}}}\right)
\end{aligned}
$$


sendo que,

$\mathrm{F}_{\mathrm{f}}$ e $\mathrm{F}_{\mathrm{t}}$ :Forças de frenagem que atuam nos respectivos eixos dianteiro e traseiro

$\mathrm{p}_{1}$ :pressão hidráulica do fluido de freio que alimenta os freios de roda

$\mathrm{p}_{\mathrm{o}}$ :pressão pré - operativa, necessária para que as sapatas de freio ou as pastilhas entrem em

contato com o tambor ou o disco

$\mathrm{A}_{\mathrm{WC}}$ :área do êmbolo do cilindro de roda do freio a tambor ou do êmbolo do freio a disco

$\eta_{\mathrm{Cf}}$ e $\eta_{\mathrm{Ct}}$ :eficiência do freio a disco e do cilindro de roda do freio a tambor

$\mathrm{BF}_{\mathrm{f}}$ e $\mathrm{BF}_{\mathrm{t}}$ : fator de freio, respectivamente, do freio dianteiro e traseiro

$r_{\text {ef }}$ e $r_{\text {et }}$ :raio efetivo do freio a disco ou do tambor de freio para os eixos dianteiro e traseiro

$\mathrm{R}_{\mathrm{D}}$ :raio dinâmico do pneu

Segundo Limpert (1999), o fator de freio BF é definido como sendo a razão entre a resistência força de atrito total gerada no disco ou no tambor por um freio pela força aplicada nas pastilhas (no caso do freio a disco) ou nas lonas (no caso do freio a tambor). Deste modo, para o veículo analisado em questão, que possui freio a disco nas quatro rodas, o fator de freio BF de um freio a disco seria igual a:

$$
\mathrm{BF}=2 \mu_{\mathrm{L}}
$$

sendo que $\mu_{\mathrm{L}}=$ coeficiente de atrito da pastilha.

Da mesma forma, os fatores de freio dos freios a tambor podem ser determinados através de cálculos (LIMPERT, 1999), ou através de métodos gráficos ou ainda, obtidos experimentalmente através de ensaios em dinamômetros.

A desaceleração do veículo foi calculada considerando as forças de frenagem nos eixos e a massa do veículo, conforme a equação abaixo:

$$
\mathrm{b}=\frac{\mathrm{F}_{\mathrm{f}}+\mathrm{F}_{\mathrm{t}}}{\mathrm{m}}
$$


sendo que:

b : desaceleração devido as forças de frenagem no veículo

$\mathrm{F}_{\mathrm{f}}$ e $\mathrm{F}_{\mathrm{t}}$ :Forças de frenagem que atuam nos respectivos eixos dianteiro e traseiro

$\mathrm{m}$ : massa total do veículo

Para determinação da força de pedal, utilizou-se o mesmo equacionamento apresentado por Limpert (1999), onde se tem:

$$
\mathrm{F}_{\mathrm{p}}=\frac{\mathrm{p}_{1} \cdot \mathrm{A}_{\mathrm{MC}}}{1_{\mathrm{p}} \cdot \eta_{\mathrm{p}}}
$$

sendo que,

$\mathrm{F}_{\mathrm{p}}$ :Força do pedal de freio

$\mathrm{p}_{1}$ : pressão hidráulica do fluido de freio que alimenta os freios de roda

$\mathrm{A}_{\mathrm{MC}}$ :área do êmbolo do cilindro mestre

$1_{\mathrm{p}}$ :relação do pedal de freio

$\eta_{\mathrm{p}}$ :eficiência do pedal de freio

Para determinação do curso de pedal, utilizou-se a seguinte equação, baseada no equacionamento apresentado por Limpert (1999):

$$
\mathrm{S}_{\mathrm{p}}=\left[\left(\frac{\Sigma \mathrm{V}_{\mathrm{i}}}{\mathrm{A}_{\mathrm{MC}}}\right)+1_{\mathrm{o}}\right] \cdot 1_{\mathrm{p}}
$$

sendo que,

$\mathrm{S}_{\mathrm{p}}$ :Curso do pedal do freio

$\mathrm{V}_{\mathrm{i}}$ : perda de volume de cada componente do freio, considerado neste programa, como sendo

originário do cilindro mestre, dos freios a disco e a tambor e das mangueiras flexíveis

$\mathrm{A}_{\mathrm{MC}}$ :área do êmbolo do cilindro mestre

$1_{\mathrm{o}}$ : curso morto relativo ao curso morto do cilindro mestre, deformação do painel da carroceria onde está montado o cilindro mestre

$1_{p}$ :relação do pedal de freio 
Apesar da modelagem utilizada neste programa de cálculo não levar em consideração as demais forças resistivas, Gardinalli (2005) apresenta a modelagem matemática das forças resistivas não consideradas, mas que estão atuantes no automóvel para determinação da força total de frenagem.

\subsection{Veículo Testado}

Os veículos utilizados na avaliação subjetiva foram automóveis de passeio, do tipo sedan e do tipo perua, equipados com motor a gasolina 1,8 litros, ambos de fabricação nacional, categoria "C", que é originalmente equipado com freio a disco nas quatro rodas, com ou sem sistema ABS.

Contudo, para comparação dos resultados relativos à avaliação subjetiva e à avaliação objetiva, utilizamos os dados referentes ao veículo sedan, equipado com motor a gasolina 1.8 litros, sem ABS, devido ao seu balanceamento de frenagem ser mais crítico que os veículos equipados com sistema ABS. A tabela 4.3 mostra os dados do veículo ensaiado. 
Tabela 4.3 - Dados do veículo ensaiado.

\begin{tabular}{|c|c|}
\hline Item & Dado \\
\hline Distância entre eixos & $2600 \mathrm{~mm}$ \\
\hline Altura do Centro de Gravidade (somente motorista) & $520,0 \mathrm{~mm}$ \\
\hline Altura do Centro de Gravidade (condição carregado (GVM)) & $470,0 \mathrm{~mm}$ \\
\hline Massa do eixo dianteiro (somente motorista) & $735,0 \mathrm{~kg}$ \\
\hline Massa do eixo traseiro (somente motorista) & $450,0 \mathrm{~kg}$ \\
\hline Massa do eixo dianteiro (condição carregado (GVM)) & $810,0 \mathrm{~kg}$ \\
\hline Massa do eixo traseiro (condição carregado (GVM)) & $685,0 \mathrm{~kg}$ \\
\hline Raio dinâmico do pneu dianteiro & $288,0 \mathrm{~mm}$ \\
\hline Raio dinâmico do pneu traseiro & $288,0 \mathrm{~mm}$ \\
\hline Tipo do freio dianteiro & Freio a disco \\
\hline Diâmetro do êmbolo do freio dianteiro & $57,0 \mathrm{~mm}$ \\
\hline Raio efetivo do freio dianteiro & $104,0 \mathrm{~mm}$ \\
\hline Pressão pré-operativa do freio dianteiro & 1,0 bar \\
\hline Tipo do freio traseiro & Freio a disco \\
\hline Diâmetro do êmbolo do freio traseiro & $34,0 \mathrm{~mm}$ \\
\hline Raio efetivo do freio traseiro & $112,0 \mathrm{~mm}$ \\
\hline Pressão pré-operativa do freio traseiro & 1,0 bar \\
\hline Tipo de válvula de controle de pressão & Válvula de corte fixo \\
\hline Pressão de corte da válvula & 15,0 bar \\
\hline Relação da válvula & 0,37 \\
\hline Tipo de cilindro mestre & Tandem \\
\hline Diâmetro do êmbolo do cilindro mestre & $20,64 \mathrm{~mm}$ \\
\hline Tipo de servo-freio & Dupla câmara a vácuo \\
\hline Diâmetro do servo-freio & 9,0 pol. \\
\hline Relação do servo-freio & 7,0 \\
\hline Jump-in ${ }^{8}$ & 45 bar \\
\hline Relação do pedal de freio & 2,8 \\
\hline
\end{tabular}

${ }^{8}$ Jump-in representa o aumento inicial da força de saída do servo-freio a uma dada força de entrada, que resulta da força de reação aplicada na haste de entrada decorrente da deformação do disco de reação (HIROTA et al, 2004). 


\section{RESULTADOS}

A seguir são apresentados os resultados comparativos entre os dois materiais de atrito (original e proposta), os resultados teóricos obtidos através da modelagem matemática entre os dois materiais de atrito, os resultados experimentais obtidos durante os ensaios práticos realizados com o veículo com a pastilha proposta e os resultados da avaliação subjetiva realizada nos veículos monitores com a pastilha proposta.

\subsection{Resultados dos materiais de atrito}

Na tabela 5.1 são mostrados os resultados comparativos dos coeficientes de atrito entre as pastilhas original (Pagid 648) e proposta (Fras-le PD/939), obtidas através do procedimento de ensaio AK-Master Dynamometer Program Test realizado pelo fabricante da pastilha.

Tabela 5.1 - Coeficientes de atrito obtidos conforme AK-Master Dynamometer Program Test.

\begin{tabular}{|c|c|c|c|l|}
\hline Item & Características & $\begin{array}{c}\text { Original } \\
\text { (Pagid 648) }\end{array}$ & $\begin{array}{c}\text { Proposta } \\
\text { (PD/939) }\end{array}$ & Observação \\
\hline 3 & $\mu \mathrm{OP} 6$ & 0,46 & 0,46 & $\mu$ médio das frenagens 1 a 6. \\
\hline 4.3 & $\mu \mathrm{V} 120$ & 0,45 & 0,46 & $\mu$ médio das frenagens a 20, 30 e 40 bar. \\
\hline 4.5 & $\mu \mathrm{V}_{\max }$ & 0,40 & 0,36 & $\mu$ médio das frenagens a 20, 30 e 40 bar. \\
\hline 5 & $\mu \mathrm{OP} 6$ & 0,41 & 0,41 & $\mu$ médio das frenagens 1 a 6. \\
\hline 6 & $\mu \mathrm{t} 40$ & 0,43 & 0,41 & $\mu$ da primeira parada. \\
\hline 7 & $\mu \mathrm{MW} 2$ & 0,47 & 0,39 & $\mu$ da segunda parada. \\
\hline 8 & $\mu \mathrm{OP} 18$ & 0,41 & 0,42 & $\mu$ médio das frenagens 1 a 18. \\
\hline 9 & $\mu \mathrm{F} 1$ & 0,36 & 0,31 & $\mu$ mínimo das frenagens 1 a 15 \\
\hline 10 & $\mu \mathrm{OP} 18$ & 0,44 & 0,45 & $\mu$ médio das frenagens 1 a 18. \\
\hline 12 & $\mu \mathrm{T} 500 / \mu \mathrm{T} 300$ & 0,35 & 0,27 & $\begin{array}{l}\mu \text { mínimo das frenagens a alta temperatura } \\
\text { conforme 12.1 e 12.2 }\end{array}$ \\
\hline 13 & $\mu \mathrm{OP} 18$ & 0,42 & 0,46 & $\mu$ médio das frenagens 1 a 18. \\
\hline 14 & $\mu \mathrm{F} 2$ & 0,38 & 0,32 & $\mu$ mínimo das frenagens 1 a 15. \\
\hline 15 & $\mu \mathrm{OP} 18$ & 0,42 & 0,45 & $\mu$ médio das frenagens 1 a 18. \\
\hline
\end{tabular}


Na tabela 5.2 são mostrados os resultados comparativos dos valores médios de compressibilidade da pastilha, conforme procedimento de ensaio TRW TS 6-11-101 (1997). Os valores de compressibilidade da pastilha representam os valores de deformação ocorridos no material de atrito devido à aplicação de pressão na plaqueta sob determinadas condições de temperatura (ambiente e alta temperatura). O gráfico da figura 5.1 compara os valores encontrados entre a pastilha original e a proposta.

Tabela 5.2 - Compressibilidade da Pastilha.

\begin{tabular}{|c|c|c|}
\hline Item & $\begin{array}{c}\text { Original } \\
\text { (Pagid 648) }\end{array}$ & $\begin{array}{c}\text { Proposta } \\
(\text { PD/939) }\end{array}$ \\
\hline \hline Compressibilidade a frio $(\mu \mathrm{m})$ & 195 & 136 \\
\hline Compressibilidade a quente $(\mu \mathrm{m})$ & 226 & 179 \\
\hline
\end{tabular}

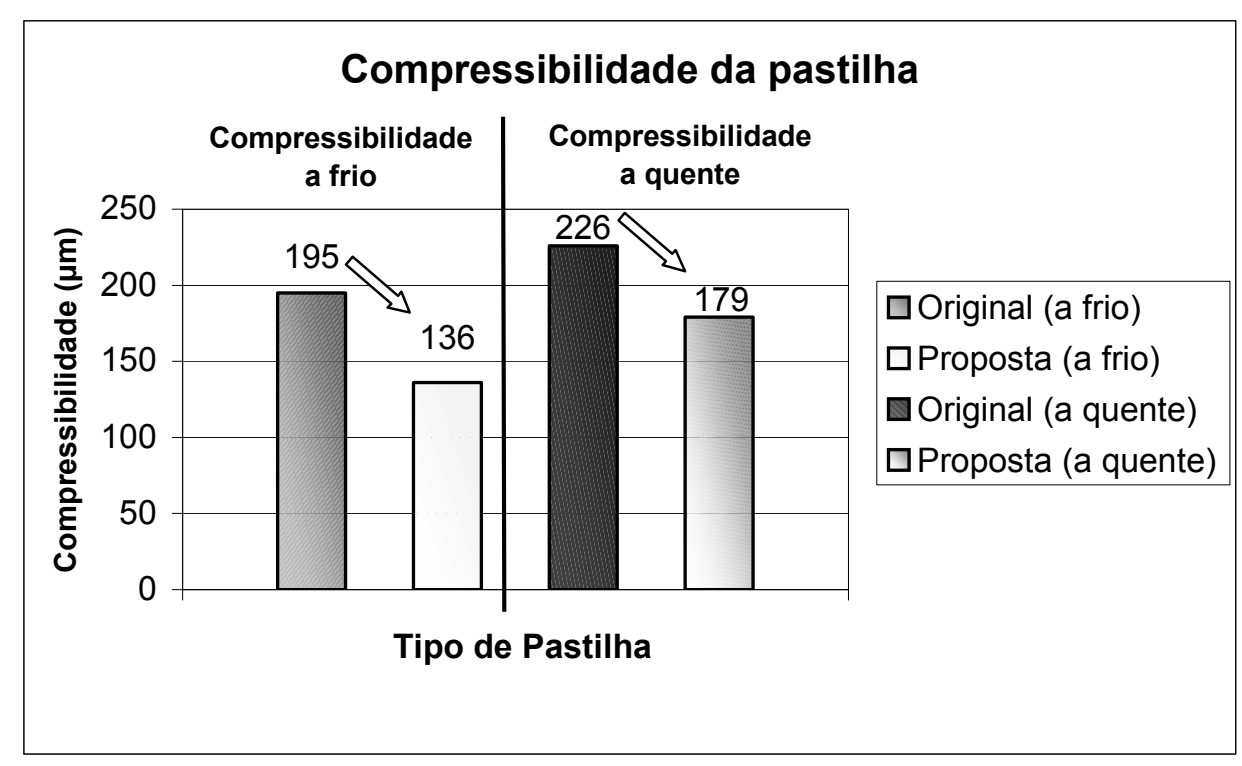

Figura 5.1 - Comparativo da compressibilidade entre a pastilha original e a proposta.

Os valores médios da compressibilidade da pastilha foram obtidos através da medição da compressibilidade a frio e a quente, para uma amostragem de quatro pastilhas de cada referência de material de atrito para cada medição. Devido à baixa quantidade do número de amostras por ensaio, pode-se perceber que a variação nos valores medidos foi relativamente grande, o que pode ser melhorado com o aumento do número de amostras a serem medidas.

Os gráficos das figuras 5.2 e 5.3 apresentam os resultados obtidos em dinamômetro inercial para avaliação de ruído, utilizando o procedimento de ensaio $A K$-Noise 
Test Procedure. Como podem ser observados, os dois materiais apresentam comportamentos diferentes na geração de ruído decorrente da frenagem.



Figura 5.2 - NPS ${ }^{9}$ máximo por freada para pastilha original.

\footnotetext{
${ }^{9}$ NPS ou Nível de Pressão Sonora são valores que indicam o total de energia sonora registrada no intervalo de freqüências do espectro selecionado.
} 


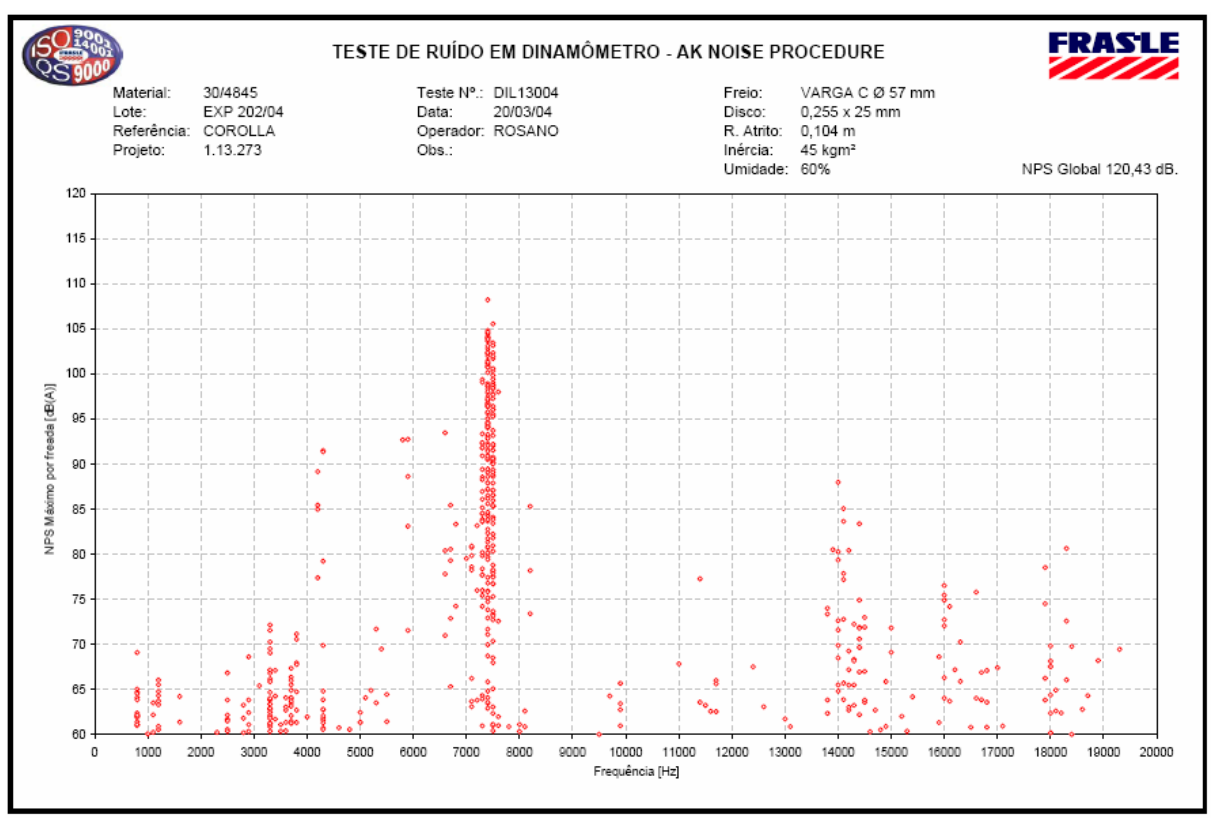

(a) Condição no início do projeto



(b) Condição no final do projeto

Figura 5.3 - NPS máximo por freada para a pastilha proposta.

Similarmente ao ensaio de dinamômetro baseado na norma AK Noise Test Procedure, realizou-se um ensaio de avaliação de ruído, baseado em procedimento de ensaio da Montadora B, simulando todas as condições de frenagem possíveis, em termos de pressão e temperatura. Os resultados do material original e proposta seguem nas figuras 5.4 e 5.5 . 


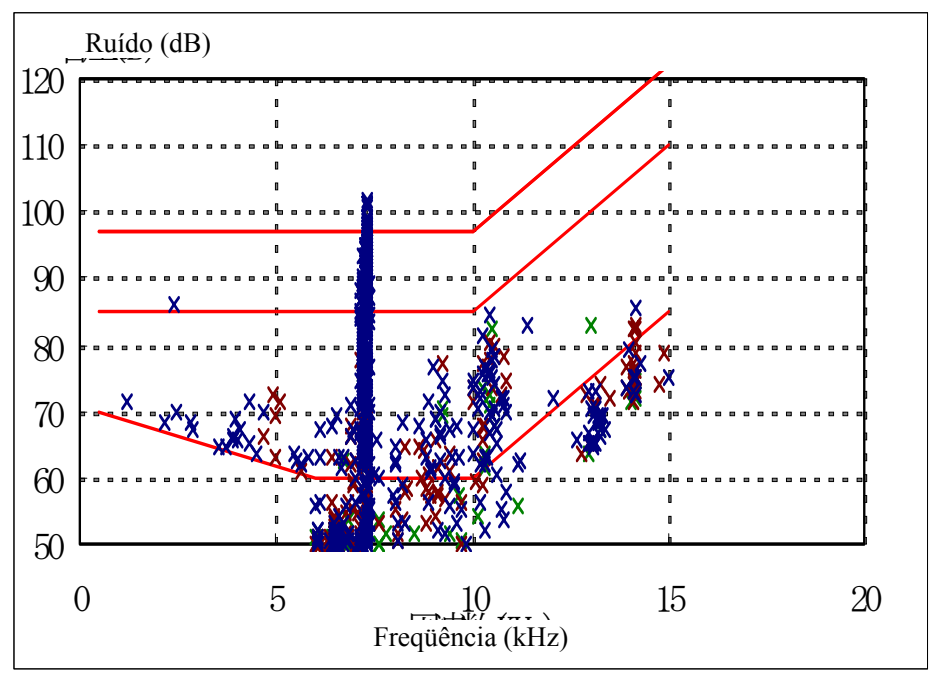

Figura 5.4 - Ensaio de ruído da pastilha original realizado conforme procedimento da Montadora B.



Figura 5.5 - Ensaio de ruído da pastilha proposta realizado conforme procedimento da Montadora B.

\subsection{Resultados da avaliação de absorção dos freios a disco}

Segue abaixo os resultados de ensaio de absorção volumétrica realizada através de aplicação de várias pressões diferentes: 30 bar, 70 bar e 100 bar, conforme procedimento padronizado da Montadora B, comparando o efeito da mudança da pastilha, da pastilha original para a pastilha proposta. Para realização deste ensaio foi utilizado um dispositivo montado em bancada de ensaio do fornecedor do sistema de freio. 
O procedimento de ensaio consiste na aplicação de uma pressão inicial de 100 bar, 5 vezes, durante $5 \mathrm{~s}$, utilizando espaçadores de $0,5 \mathrm{~mm}$ de espessura entre a pastilha e o disco para acomodação inicial. Após isso, são removidos os espaçadores e são aplicadas novamente pressões de acomodação inicial 5 vezes e com 1 min de manutenção, para em seguida realizar a medição da pressão desejada. A tabela 5.3 mostra os valores de pressão de acomodação e os respectivos valores de medição.

Tabela 5.3 - Dados de pressão de acomodação.

\begin{tabular}{|c|c|}
\hline Pressão de leitura & Pressão de acomodação \\
\hline \hline 30 bar & 10 bar \\
\hline 70 bar & 30 bar \\
\hline 100 bar & 70 bar \\
\hline
\end{tabular}

Os gráficos das figuras 5.6, 5.7 e 5.8 compara os valores de absorção volumétrica médio entre a pastilha original e a pastilha proposta, respectivamente para valores de medição de 30 bar, 70 bar e 100 bar. Foram realizadas 8 medições em 4 conjuntos de freio a disco para a pastilha proposta, enquanto, por uma limitação de disponibilidade de amostras, foram somente realizadas 4 medições em 2 conjuntos de freio a disco com a pastilha original. O requisito de projeto para o freio a disco estabelece que a absorção máxima para uma pressão de 30 bar seja de $1,77 \mathrm{~cm}^{3}$. A tabela 5.4 mostra os valores médios encontrados para cada uma das pastilhas, considerando a condição de medição de 30 bar.

Tabela 5.4 - Absorção volumétrica comparativa em função da pressão aplicada (condição de ensaio: pressão de medição de 30 bar).

\begin{tabular}{|c|c|c|c|}
\hline Pressão (bar) & $\begin{array}{c}\text { Absorção }\left(\mathrm{cm}^{3}\right) \\
\text { Pastilha Original }\end{array}$ & $\begin{array}{c}\text { Absorção }\left(\mathrm{cm}^{3}\right) \\
\text { Pastilha Proposta }\end{array}$ & Variação Percentual \\
\hline \hline 0 & 0,000 & 0,000 & $0 \%$ \\
\hline 5,0 & 0,733 & 0,802 & $+8,60 \%$ \\
\hline 10,0 & 0,973 & 0,955 & $-1,88 \%$ \\
\hline 15,0 & 1,156 & 1,083 & $-6,74 \%$ \\
\hline 20,0 & 1,321 & 1,198 & $-10,27 \%$ \\
\hline 25,0 & 1,470 & 1,309 & $-12,30 \%$ \\
\hline 30,0 & 1,611 & 1,412 & $-14,09 \%$ \\
\hline
\end{tabular}




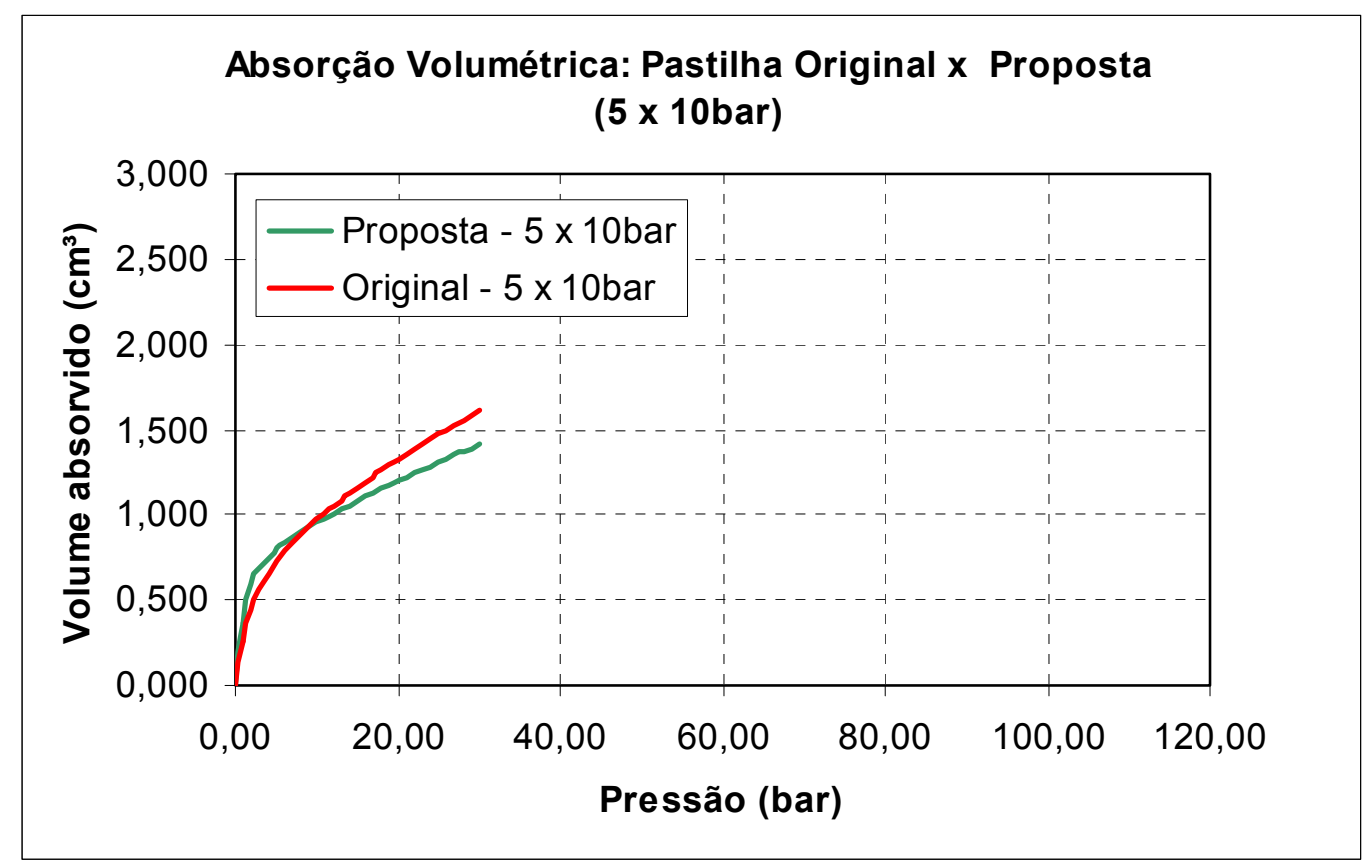

Figura 5.6 - Absorção volumétrica comparativa (pressão de leitura: 30bar).

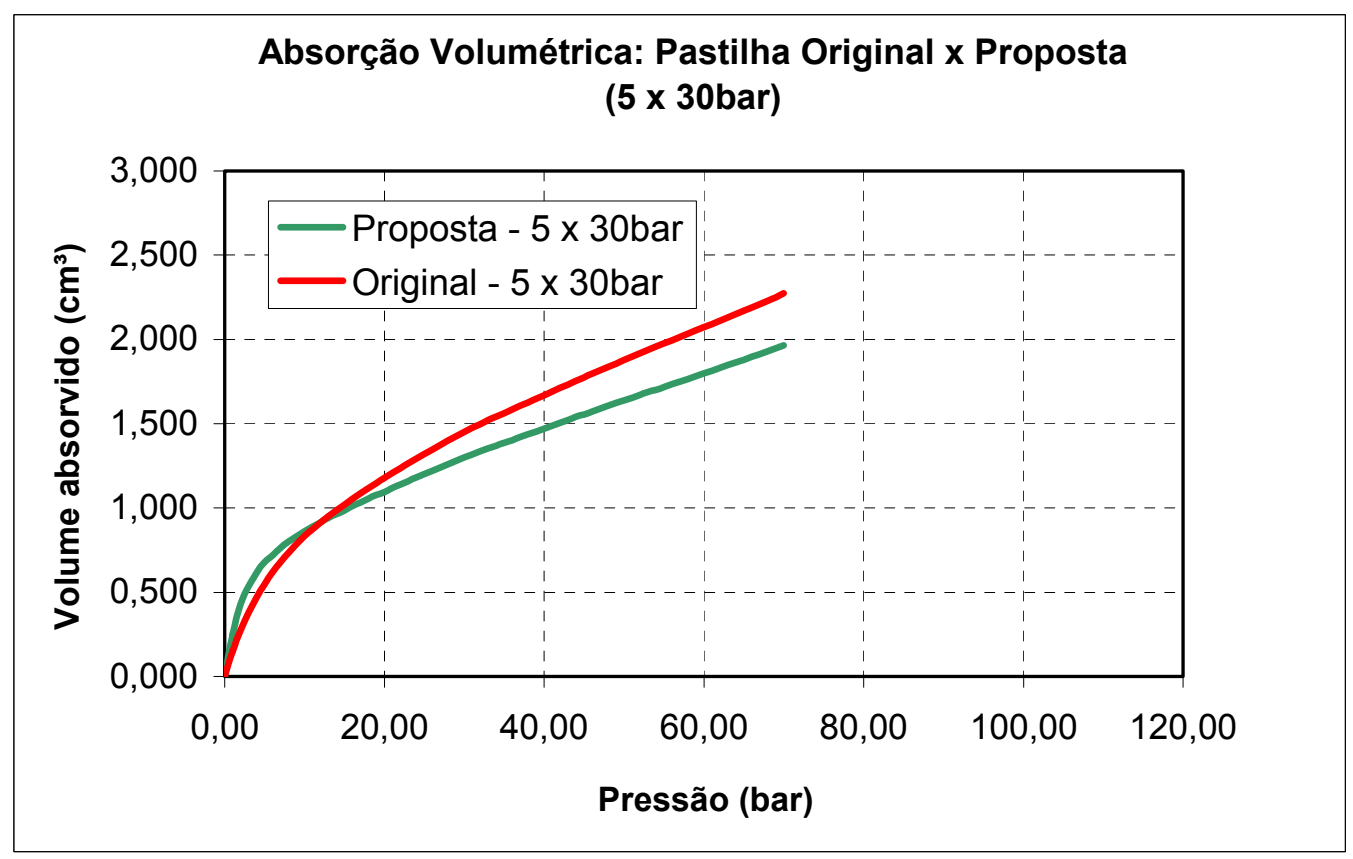

Figura 5.7 - Absorção volumétrica comparativa (pressão de leitura: 70bar). 




Figura 5.8 - Absorção volumétrica comparativa (pressão de leitura: 100bar).

A tabela 5.5 mostra os valores para cada pastilha para a pressão de leitura de 30 bar, para verificação do atendimento do requisito de projeto estabelecido para este sistema de freio.

Tabela 5.5 - Absorção volumétrica para a pressão de leitura de 30 bar.

\begin{tabular}{|c|c|c|c|}
\hline \multicolumn{4}{|c|}{ Absorção Volumétrica $\left(\mathbf{c m}^{\mathbf{3}}\right.$ ) - valores médios } \\
\hline \multicolumn{2}{|c|}{ Pressão (bar) } & $\mathbf{3 0}$ & Resultado \\
\hline \multirow{4}{*}{$\begin{array}{c}\text { Com } \\
\text { pastilhas }\end{array}$} & Amostra 1 Esq & 1,50 & Aprovado \\
\cline { 2 - 4 } & Amostra 2 Esq & 1,34 & Aprovado \\
\cline { 2 - 4 } & Amostra 3 Dir & 1,34 & Aprovado \\
\cline { 2 - 4 } & Amostra 4 Dir & 1,46 & Aprovado \\
\hline
\end{tabular}

\subsection{Resultados da modelagem matemática}

Baseado nos dados do veículo, nos valores encontrados para os coeficientes de atrito da pastilha original x proposta e nos valores de absorção encontrados entre freios a disco montados com a pastilha original $\mathrm{x}$ proposta, realizamos as seguintes análises na modelagem matemática utilizada no programa de cálculo do sistema de freio, considerando as seguintes condições: 


\subsubsection{Coeficientes de atrito equivalentes entre a pastilha original e a pastilha proposta}

Neste caso, observando que as duas pastilhas apresentam níveis de coeficiente de atrito muito similares, realizou-se a análise dos itens relacionados a conforto de frenagem força de acionamento do pedal, curso do pedal e desaceleração - considerando como hipótese, que ambas oferecessem o mesmo nível de coeficiente de atrito $\left(\mu_{\text {médio }}=0,42\right)$, mas, utilizando para cada pastilha, os respectivos resultados de absorção volumétrica que caracterizam o comportamento de cada material de atrito. As figuras 5.9, 5.10, 5.11 e 5.12 mostram os resultados obtidos nas análises das pastilhas original versus proposta, apresentando também as condições limites de aceitação considerados para avaliação de cada quesito, segundo critérios de Montadoras A e B.

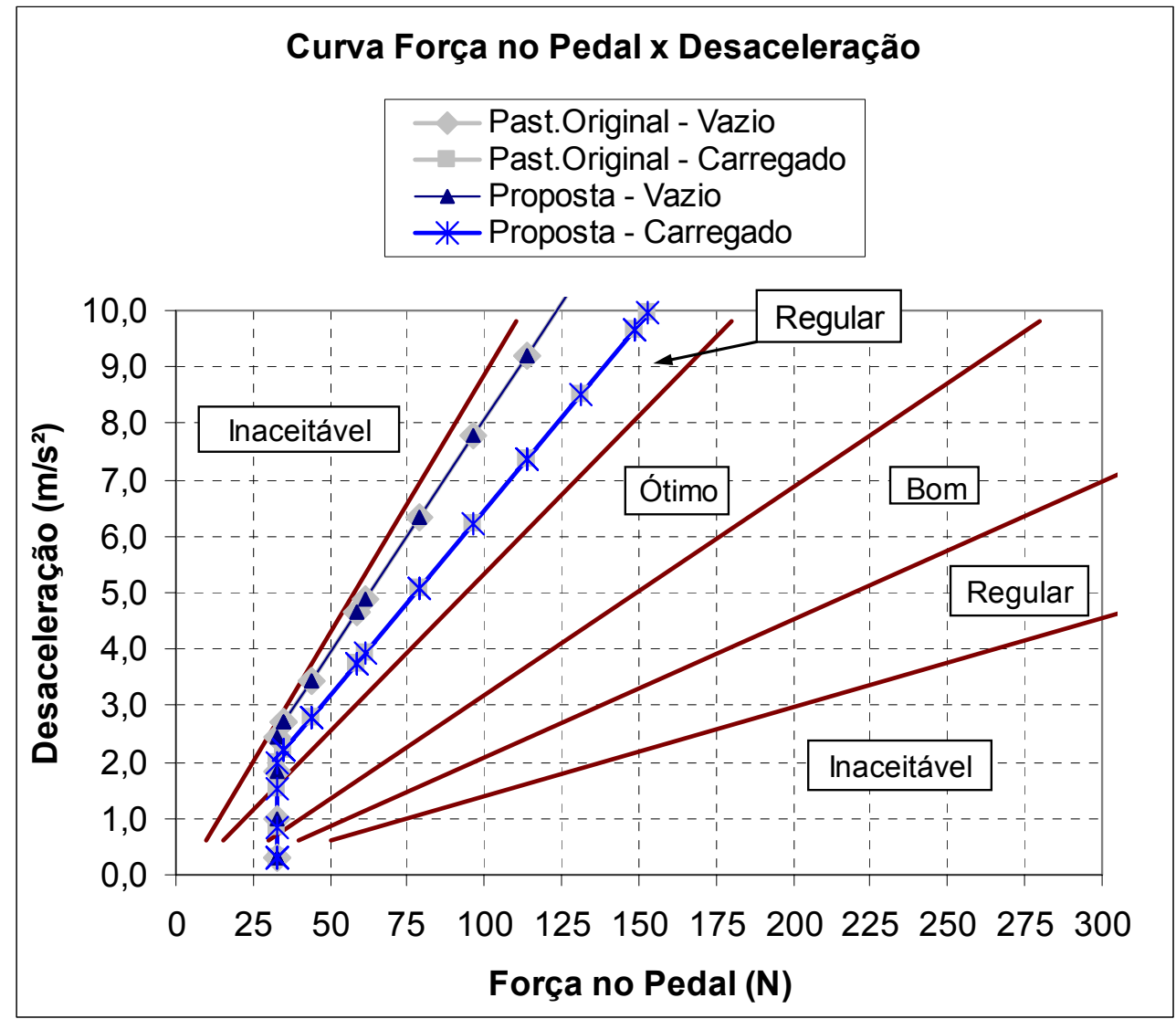

Figura 5.9 - Força no pedal $x$ desaceleração nas condições de carregamento vazio (somente com motorista) e carregado (GVM), considerando o mesmo coeficiente de atrito entre as pastilhas original e proposta (Montadora $\mathrm{A})$. 


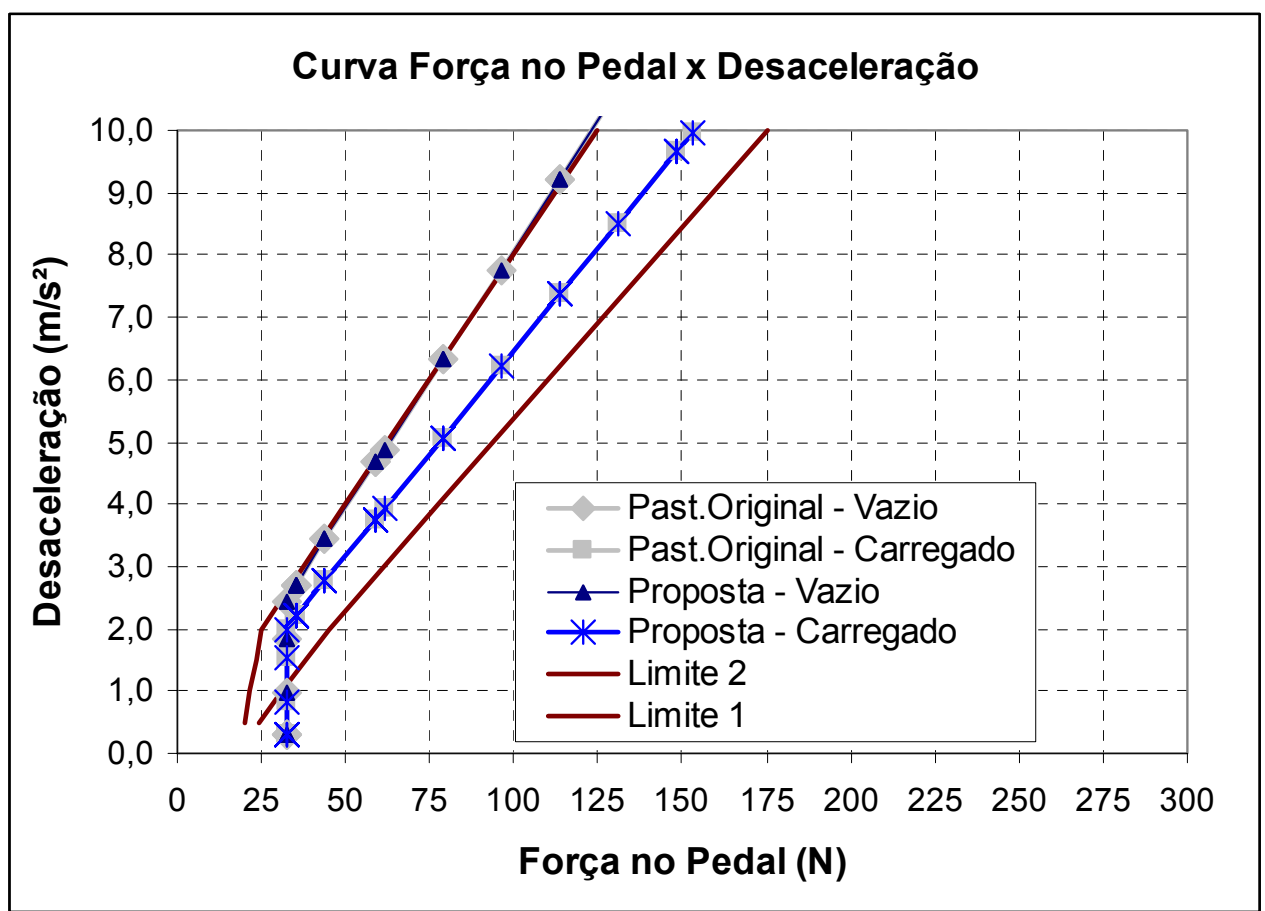

Figura 5.10 - Força no pedal $x$ desaceleração nas condições de carregamento vazio (somente com motorista) e carregado (GVM), considerando o mesmo coeficiente de atrito entre as pastilhas original e proposta (Montadora $B$ ).



Figura 5.11 - Curso do pedal $x$ desaceleração nas condições de carregamento vazio (somente com motorista) e carregado (GVM), considerando o mesmo coeficiente de atrito para a pastilha original e proposta (Montadora $B$ ). 


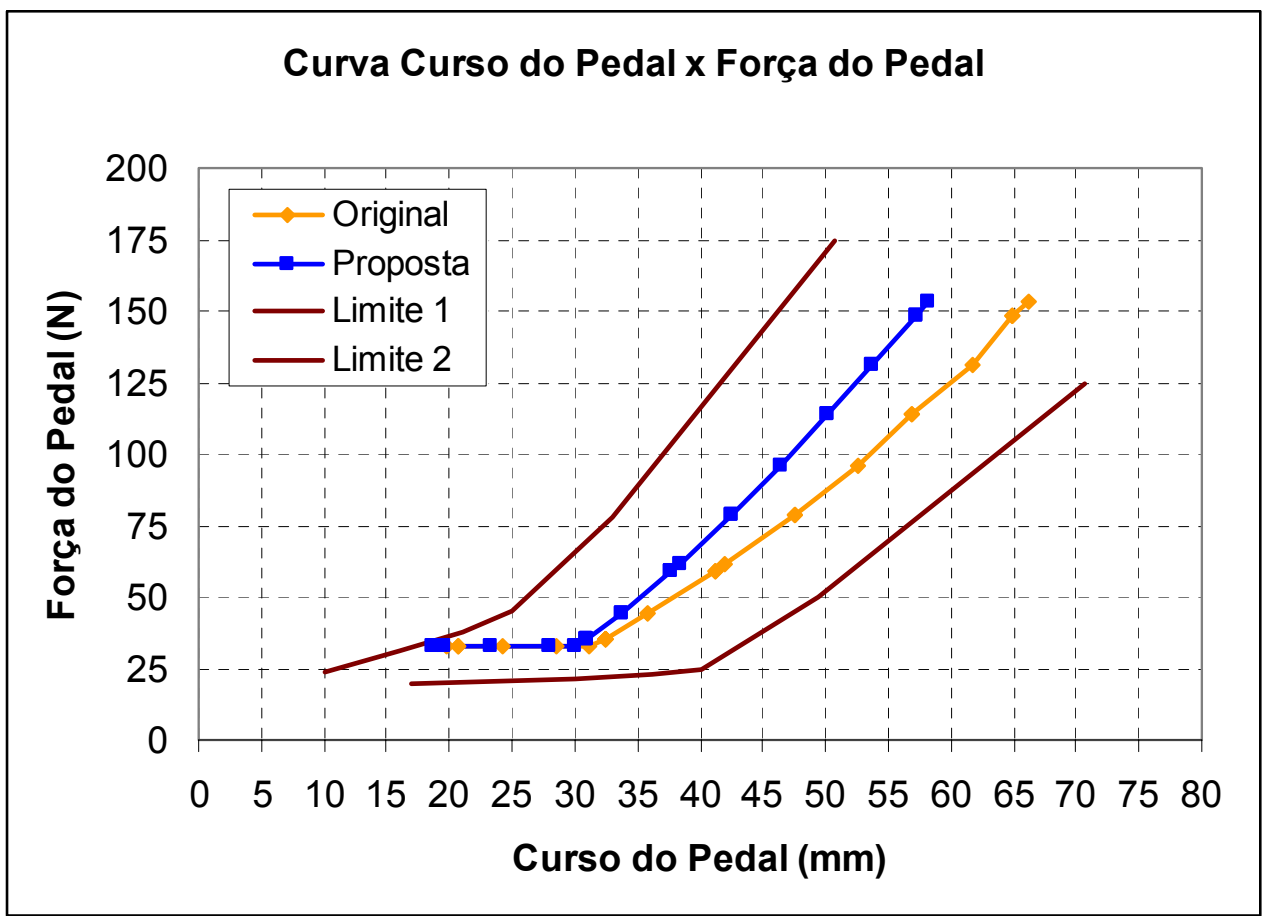

Figura 5.12 - Curso do pedal $x$ força do pedal, considerando o mesmo coeficiente de atrito entre a pastilha original e proposta (Montadora B).

\subsubsection{Coeficientes de atrito diferentes entre a pastilha original e a pastilha proposta}

Neste caso, foi realizada a mesma análise do item anterior, mas considerando que a pastilha original $\left(\mu_{\text {médio }}=0,42\right)$ e a pastilha proposta $\left(\mu_{\text {médio }}=0,46\right)$ tenham coeficientes de atrito diferentes. Em decorrência do fato de serem observados desempenhos de atrito diferentes entre os dois materiais de atrito, considerável normal em se tratando de duas formulações diversas. Foram considerados os respectivos resultados de absorção volumétrica de cada pastilha. As figuras 5.13, 5.14, 5.15 e 5.16 mostram os resultados obtidos nas análises das pastilhas originais versus proposta, apresentando também as condições limites de aceitação considerados para avaliação de cada quesito, segundo critérios de Montadoras A e B. 


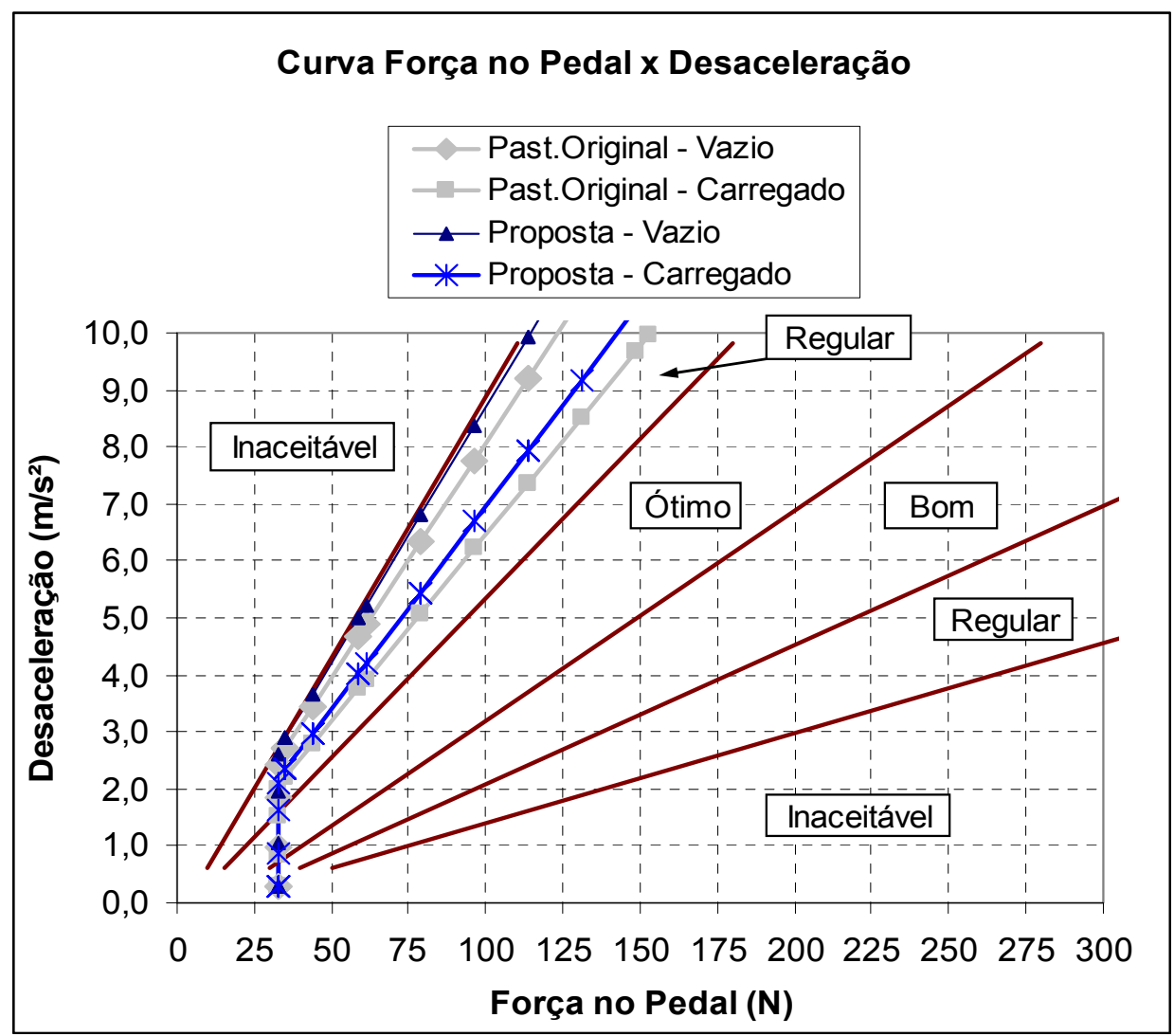

Figura 5.13 - Força no pedal $x$ desaceleração nas condições de carregamento vazio (somente com motorista) e carregado (GVM), considerando diferentes coeficientes de atrito entre as pastilhas original e proposta (Montadora $\mathrm{A})$.

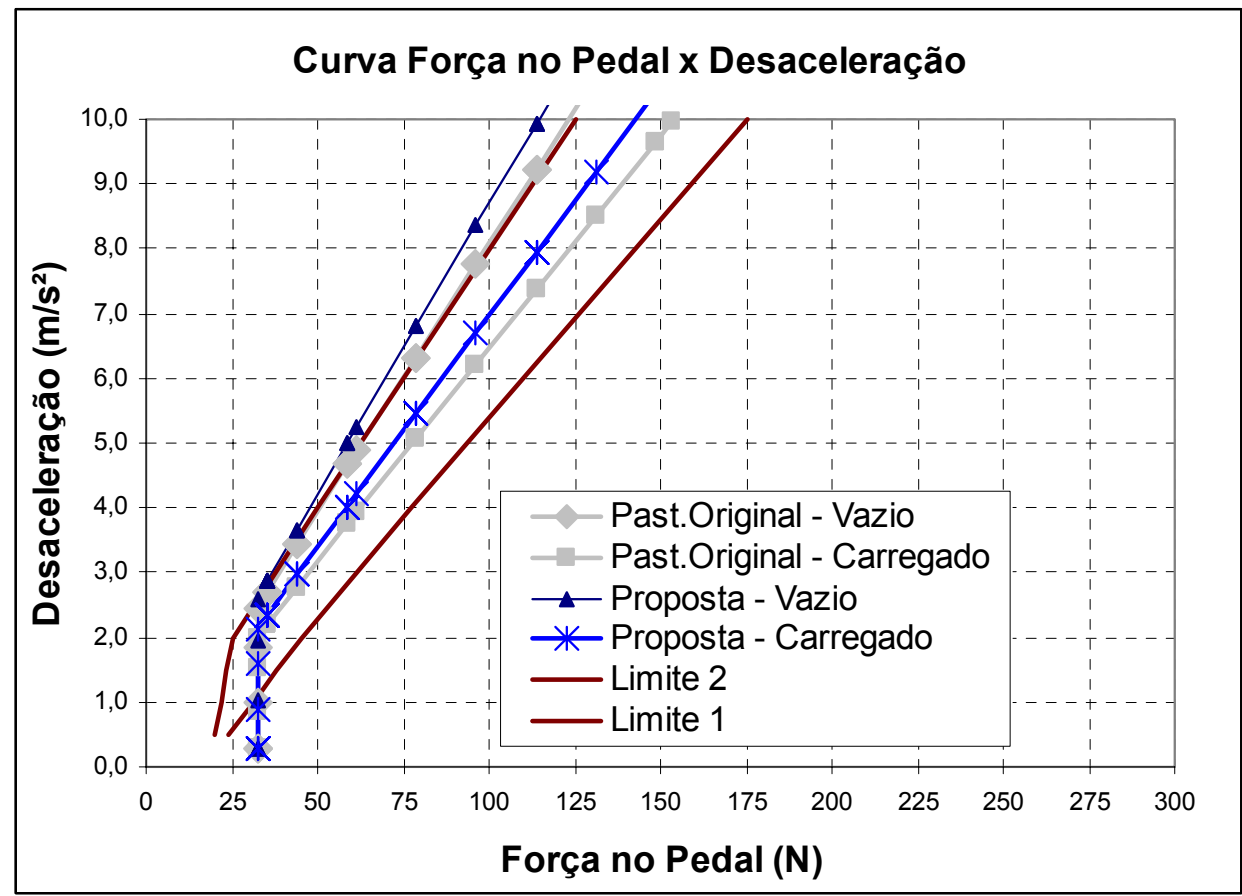

Figura 5.14 - Força no pedal $x$ desaceleração nas condições de carregamento vazio (somente com motorista) e carregado (GVM), considerando diferentes coeficientes de atrito entre as pastilhas original e proposta (Montadora B). 


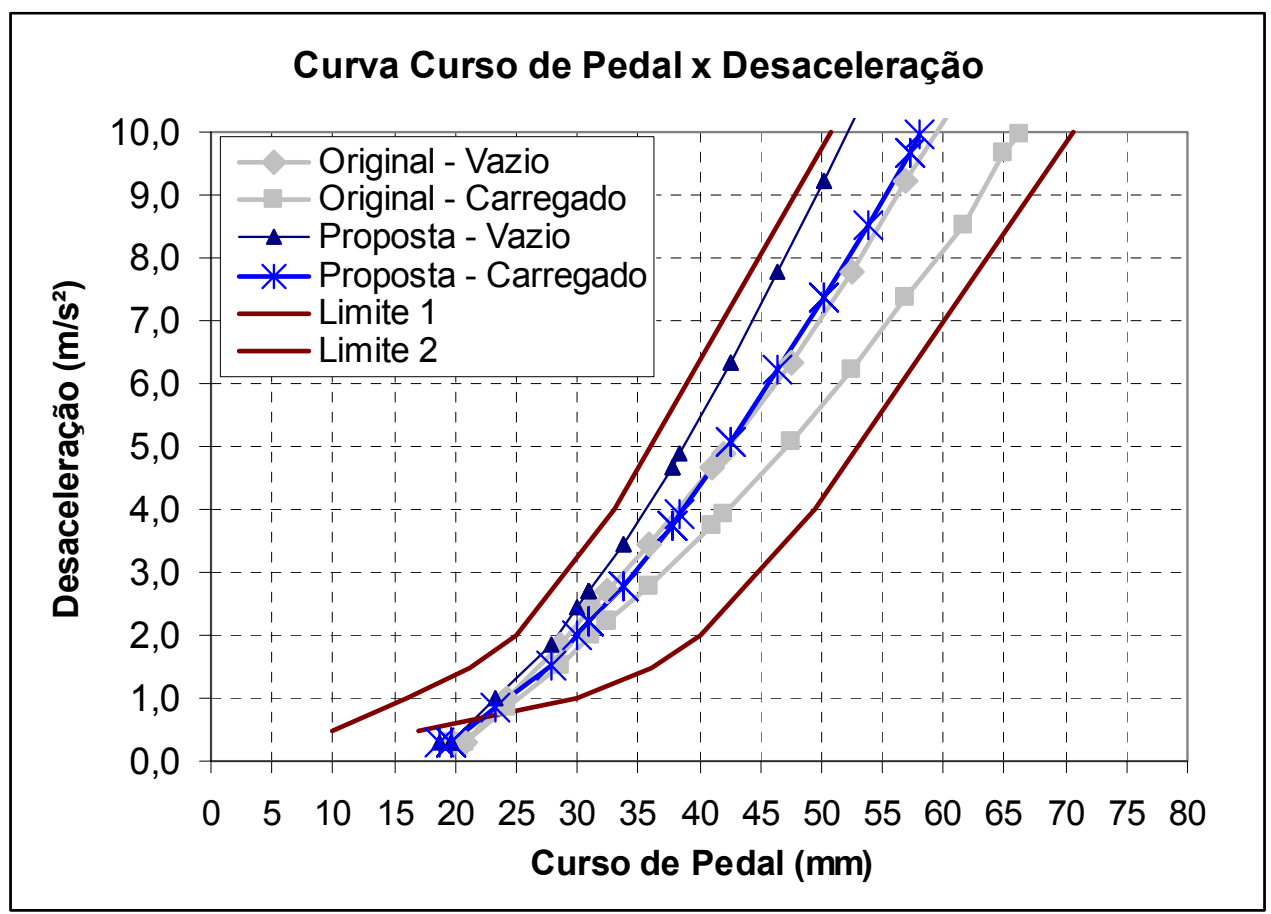

Figura 5.15 - Curso do pedal $x$ desaceleração nas condições de carregamento vazio (somente com motorista) e carregado (GVM), considerando diferentes coeficientes de atrito para a pastilha original e proposta (Montadora $B$ ).



Figura 5.16 - Curso do pedal $x$ força do pedal, considerando diferentes coeficientes de atrito entre a pastilha original e proposta (Montadora B). 


\subsection{Resultado das provas experimentais}

Foram obtidos resultados de medições experimentais com a pastilha proposta, realizados no veículo objeto da análise desse estudo de caso. As figuras 5.17 e 5.18 mostram respectivamente os resultados de desaceleração em função do esforço de pedal e do curso de pedal. Apresentam-se nos respectivos gráficos, as respectivas curvas teóricas calculadas no programa de modelagem matemática deste veículo para efeito de comparação com os dados experimentais.



Figura 5.17 - Esforço de Pedal x Desaceleração: Medições Experimentais x Modelagem Matemática. 


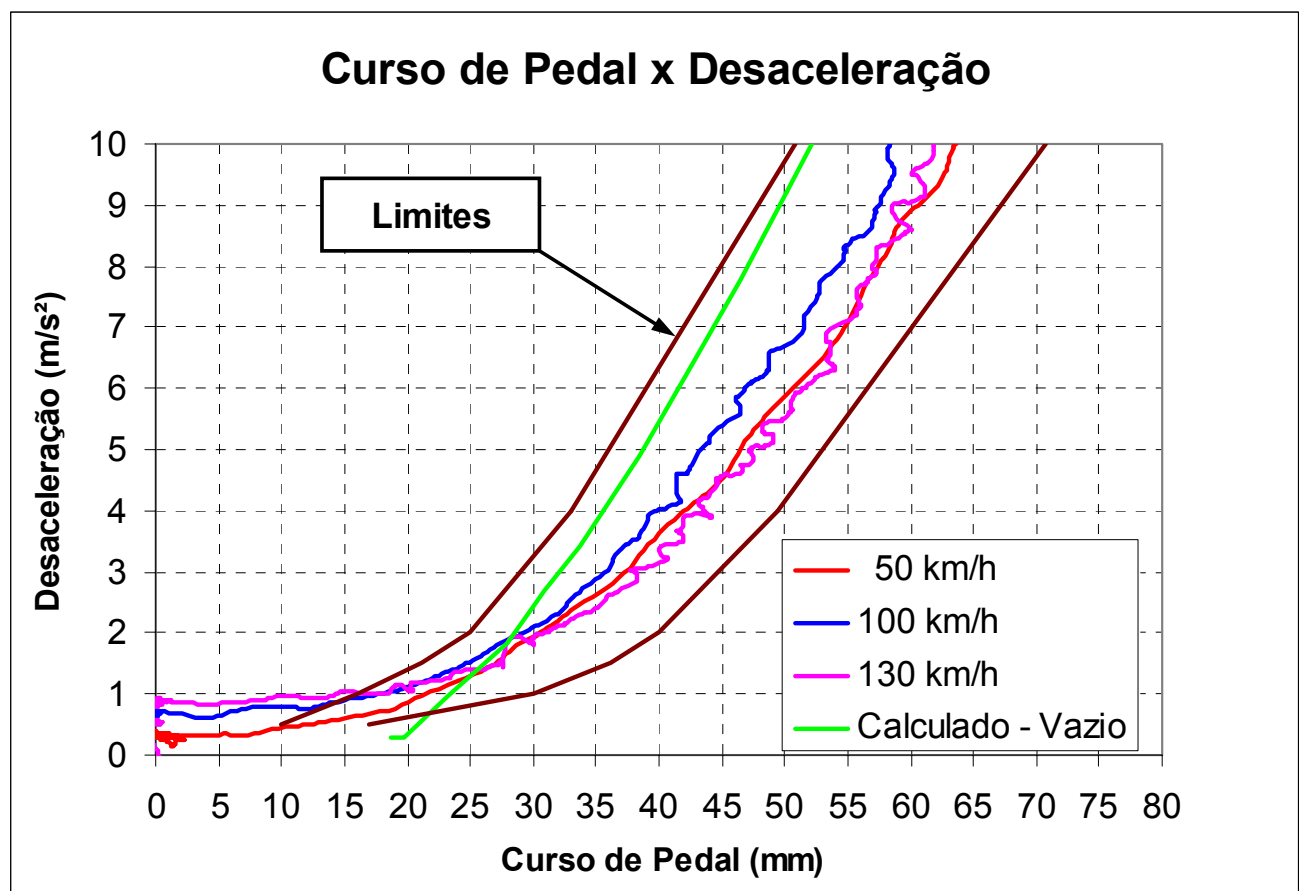

Figura 5.18 - Curso de Pedal x Desaceleração: Medições Experimentais x Modelagem Matemática.

\subsection{Resultados da avaliação subjetiva}

A tabela 5.6 mostra os resultados da avaliação subjetiva, utilizando o critério de pontuação estabelecido no procedimento "Vehicle Screening Test" utilizado pela Montadora B. Conforme mencionado no capítulo anterior, foram avaliados apenas os itens relacionados à sensação de freio, vibração e ruído de frenagem. Foram coletadas as opiniões de 10 pessoas que participaram do ensaio de monitoramento da pastilha proposta, dentre as quais 5 pessoas eram usuários normais do veículo avaliado, utilizando no translado diário entre residência e o local de trabalho. Os demais 5 participantes foram técnicos especialistas e engenheiros responsáveis pela avaliação veicular ou pelo projeto de sistemas de freio, sendo um deles representante da matriz da Montadora B, que participou na validação da pastilha proposta para o veículo objeto do estudo. 
Tabela 5.6 - Resultados da Avaliação Subjetiva.



Nota: As cores são indicações da individualidade dos participantes e os símbolos seguem as indicações conforme explanado a seguir:

$\triangle$ - Especialista técnico de avaliação de freio da matriz;

- Especialista técnico ou engenheiro de freio participante do projeto de nacionalização da pastilha;

- Usuários participantes do teste de monitoramento. 


\section{DISCUSSÃO DOS RESULTADOS}

De um modo geral, ao considerar os resultados obtidos na avaliação objetiva e na avaliação subjetiva, constataram-se resultados similares aos encontrados por Basch et al. (2002), que ao analisarem a correlação das propriedades do material de atrito das pastilhas de freio, observaram correlações sutis, mas mensuráveis com relação aos dados objetivos medidos, mas não mostraram diferenças significativas estatisticamente entre as pastilhas de freio. No estudo de caso apresentado, onde a análise objetiva foi conduzida através da simulação matemática do sistema de freio, tais correlações com as propriedades do material de atrito das pastilhas também puderam ser observadas, comparando os dados das figuras 5.6 a 5.8 com os resultados simulados das figuras 5.9 a 5.12, para pastilha original e proposta com mesmo coeficiente de atrito, e até mesmo nos resultados simulados das figuras 5.13 a 5.16.

Em relação aos resultados da análise subjetiva, a escolha do material da pastilha proposta em substituição ao material da pastilha original atende a um dos objetivos da motivação da mudança de material de atrito, descrito no Capítulo 4, de modo a proporcionar diferenças mínimas no desempenho e no conforto de frenagem do veículo, proporcionando assim, a total intercambiabilidade entre os dois materiais, uma vez que este veículo já se encontra em produção, e o propósito de utilização da pastilha proposta abrangeria não só os que fossem produzidos após a implementação da pastilha proposta, mas atender as reposições dos veículos já produzidos. Contudo, os resultados apresentados por pessoas especialistas em avaliação ou engenheiros especialistas em projetos de sistemas de freio, puderam perceber uma sensível melhora no nível de conforto de frenagem, que pode ser observada pela diminuição de curso de pedal necessário para os mesmos níveis de desaceleração, apresentados nas figuras 5.11 e 5.15 do Capítulo anterior.

Entretanto, considerando-se que na maior parte do tempo, os motoristas utilizam o sistema de freio do veículo, desacelerando-o numa faixa entre 0 a $3,0 \mathrm{~m} / \mathrm{s}^{2}$ 
(HARRIES, 1978), pode-se observar a existência de uma correlação entre os resultados simulados da análise objetiva com os dados coletados na avaliação subjetiva, devido à pequena diferença em termos de força de pedal e curso de pedal entre a pastilha original e proposta observada nesta faixa de desaceleração aplicada ao veículo. A tabela 6.1 e 6.2 apresenta os dados obtidos nesta faixa de desaceleração, para materiais de atrito com coeficientes de atrito iguais e a tabela 6.3 e 6.4, para os materiais de atrito com coeficientes de atrito diferentes.

Tabela 6.1 - Força do pedal x desaceleração (faixa de 0 a $3,0 \mathrm{~m} / \mathrm{s}^{2}$ ).

\begin{tabular}{|c|c|c|c|}
\hline $\begin{array}{c}\text { Desaceleração } \\
\left(\mathbf{m} / \mathbf{s}^{\mathbf{2}}\right)\end{array}$ & $\begin{array}{c}\text { Força do Pedal (N) } \\
\text { Pastilha Original }\end{array}$ & $\begin{array}{c}\text { Força do Pedal (N) } \\
\text { Pastilha Proposta }\end{array}$ & Diferença (N) \\
\hline $\mathbf{0 , 0}$ & $\mathbf{0 , 0}$ & $\mathbf{0 , 0}$ & $\mathbf{0 , 0}$ \\
\hline 1,0 & $\mathbf{3 2 , 5}$ & $\mathbf{3 2 , 5}$ & $\mathbf{0 , 0}$ \\
\hline $\mathbf{2 , 0}$ & $\mathbf{3 2 , 5}$ & $\mathbf{3 2 , 5}$ & $\mathbf{0 , 0}$ \\
\hline $\mathbf{3 , 0}$ & $\mathbf{3 7 , 7}$ & $\mathbf{3 7 , 7}$ & $\mathbf{0 , 0}$ \\
\hline
\end{tabular}

Tabela 6.2 - Curso no pedal x desaceleração (faixa de 0 a $3,0 \mathrm{~m} / \mathrm{s}^{2}$ )

\begin{tabular}{|c|c|c|c|}
\hline $\begin{array}{c}\text { Desaceleração } \\
\left(\mathbf{m} / \mathbf{s}^{2}\right)\end{array}$ & $\begin{array}{c}\text { Curso do Pedal }(\mathbf{m m}) \\
\text { Pastilha Original }\end{array}$ & $\begin{array}{c}\text { Curso do Pedal }(\mathbf{m m}) \\
\text { Pastilha Proposta }\end{array}$ & $\begin{array}{c}\text { Diferença } \\
(\mathbf{m m})\end{array}$ \\
\hline $\mathbf{0 , 0}$ & $\mathbf{0 , 0}$ & $\mathbf{0 , 0}$ & $\mathbf{0 , 0}(\mathbf{0 , 0} \%)$ \\
\hline 1,0 & 24,2 & 23,2 & $1,0(4,1 \%)$ \\
\hline 2,0 & 29,3 & 28,5 & $0,8(2,9 \%)$ \\
\hline 3,0 & 34,2 & 32,4 & $1,8(5,2 \%)$ \\
\hline
\end{tabular}

Tabela 6.3 - Força do pedal x desaceleração (faixa de 0 a $3,0 \mathrm{~m} / \mathrm{s}^{2}$ ).

\begin{tabular}{|c|c|c|c|}
\hline $\begin{array}{c}\text { Desaceleração } \\
\left(\mathbf{m} / \mathbf{s}^{2}\right)\end{array}$ & $\begin{array}{c}\text { Força do Pedal (N) } \\
\text { Pastilha Original }\end{array}$ & $\begin{array}{c}\text { Força do Pedal (N) } \\
\text { Pastilha Proposta }\end{array}$ & Diferença (N) \\
\hline $\mathbf{0 , 0}$ & $\mathbf{0 , 0}$ & $\mathbf{0 , 0}$ & $\mathbf{0 , 0}$ \\
\hline 1,0 & 32,5 & 32,5 & 0,0 \\
\hline 2,0 & 32,5 & $\mathbf{3 2 , 5}$ & $\mathbf{0 , 0}$ \\
\hline $\mathbf{3 , 0}$ & 37,7 & $\mathbf{3 6 , 5}$ & $\mathbf{1 , 2}(\mathbf{3 , 2} \%)$ \\
\hline
\end{tabular}


Tabela 6.4 - Curso no pedal x desaceleração (faixa de 0 a $3,0 \mathrm{~m} / \mathrm{s}^{2}$ ).

\begin{tabular}{|c|c|c|c|}
\hline $\begin{array}{c}\text { Desaceleração } \\
\left(\mathbf{m} / \mathbf{s}^{\mathbf{2}}\right)\end{array}$ & $\begin{array}{c}\text { Curso do Pedal }(\mathbf{m m}) \\
\text { Pastilha Original }\end{array}$ & $\begin{array}{c}\text { Curso do Pedal }(\mathbf{m m}) \\
\text { Pastilha Proposta }\end{array}$ & $\begin{array}{c}\text { Diferença } \\
(\mathbf{m m})\end{array}$ \\
\hline $\mathbf{0 , 0}$ & $\mathbf{0 , 0}$ & $\mathbf{0 , 0}$ & $\mathbf{0 , 0}(\mathbf{0 , 0} \%)$ \\
\hline 1,0 & 24,2 & 23,2 & $1,0(4,1 \%)$ \\
\hline 2,0 & 29,3 & 28,5 & $\mathbf{0 , 8}(2,9 \%)$ \\
\hline 3,0 & 34,2 & 32,4 & $1,8(5,2 \%)$ \\
\hline
\end{tabular}

Nota-se que as diferenças observadas, em termos de curso de pedal, quando comparadas ao efeito da mudança do material de atrito nesta faixa de desaceleração, são menores do que 2,0 $\mathrm{mm}$, ou seja, representa $1,29 \%$ do curso total disponível do pedal de freio (140 mm) seria pouco relevante para a sensibilidade do motorista, quando se observa os resultados da avaliação subjetiva.

A análise das curvas simuladas pelo modelo matemático e das tabelas anteriores demonstra que o coeficiente de atrito influencia diretamente na desaceleração observada no veículo, mesmo que sutilmente, apesar de que se deve levar em consideração a necessidade de um bom equilíbrio do sistema de freio para o seu perfeito funcionamento, sem que haja necessidade de se alterar a especificação de outros componentes, uma vez que as diferenças de $10 \%$ do coeficiente de atrito entre os dois materiais estariam dentro da faixa de tolerância geral observada na produção de materiais de atrito, segundo padrões de controle de qualidade dos fabricantes de materiais de atrito. Já a compressibilidade do material de atrito da pastilha, atua diretamente na absorção volumétrica do freio a disco, impactando diretamente nos curso de pedal do sistema de freio para as mesmas aplicações de força no pedal.

Na comparação dos resultados simulados pelo modelo matemático utilizado e dos resultados obtidos através de medições experimentais, conforme as figuras 5.17 e 5.18, observa-se que o modelo matemático utilizado apresentou uma boa aproximação com relação à variação do esforço de pedal com relação à desaceleração obtida no veículo, conforme 
podendo apresentar uma boa estimativa tanto aos projetistas de sistema de freio, quanto a aqueles que deverão adequá-lo ao veículo, o que permite de certa forma desconsiderar as outras forças resistivas ao movimento do veículo, que influenciariam o resultado das forças de frenagem atuantes no veículo, apresentado como hipótese simplificadora anteriormente. Entretanto, as demais forças resistivas além da força de frenagem justificam a ocorrência de desacelerações constantes para valores de força de pedal, entre $0 \mathrm{~N}$ e 32,5 $\mathrm{N}$, que representaria a região onde a força aplicada pelo pedal de freio estaria vencendo as resistências internas da mola de retorno do pedal, das molas de retorno do servo-freio e do cilindro mestre.

Já com relação ao curso de pedal de freio, apesar de se aproximar do comportamento dinâmico observado no veículo, os valores teóricos são um pouco menores aos valores experimentais. Este fato é decorrente da hipótese inicial, na qual o modelo matemático utilizado desconsiderava as perdas de volume decorrente da aplicação de pressão no sistema de freio devido à expansão volumétrica dos tubos de freio e no cilindro mestre, à existência de ar ou gás remanescente pós-sangria do sistema de freio e inclusive, de uma pequena parcela devido à compressibilidade do fluido de freio (Limpert, 1999). O modelo pode ser perfeitamente melhorado para que se obtenha uma maior aproximação entre os dados obtidos no veículo e os dados obtidos através de medição experimental.

Apesar de não ser objetivo principal deste trabalho, considerou-se importante analisar os resultados obtidos com relação ao ruído apresentado durante o desenvolvimento da aplicação da pastilha proposta com relação à pastilha original. Segundo os resultados das figuras 5.2 e 5.3, baseados em dados obtidos em dinamômetro, e figuras 5.4 e 5.5, obtidas em dinamômetros de chassis, com relação ao nível de ruído, o material proposta apresentou níveis de ruído superiores ao material original, resultando na necessidade de promover modificações na sua composição que melhorassem o seu desempenho. Devido ao longo trabalho realizado, 
tanto em termos de ensaios de bancada, quanto em ensaios veiculares, este fato contradiz o argumento de que a mudança de materiais de atrito sejam relativamente simples e de custo relativamente baixo, caso a proposta para a mudança de sensação de pedal seja insatisfatória por outros meios, segundo Basch et. al (2002). 


\section{CONCLUSÕES}

O desenvolvimento de sistemas de freio para veículos automotivos não se restringe somente ao atendimento de normas e regulamentos estabelecidos pelos diversos órgãos que definem a legislação de trânsito. Alguns dos itens, tais como conforto de frenagem, apesar de não serem definidos, especificamente, nas regulamentações, é parte importante na definição do projeto do sistema de freio pois estabelece a relação: sensação do motorista/resposta do veículo durante a frenagem. Os diversos parâmetros de projeto utilizados para cálculo e dimensionamento do sistema de freio permitem que cada empresa montadora de veículos apresente diversos resultados na sensação de pedal percebida nos seus diversos veículos.

A partir dos resultados obtidos neste trabalho, apresentados nas tabelas $6.1 \mathrm{a}$ 6.4, podem-se constatar uma correlação entre a avaliação subjetiva e a avaliação objetiva do conforto de frenagem, conforme a metodologia desenvolvida através de simulação matemática, observando as condições do meio e da forma como estas são realizadas (frenagens com desacelerações entre 0 a $3,0 \mathrm{~m} / \mathrm{s}^{2}$ ).

Observou-se que na literatura pesquisada, as variáveis que representam objetivamente a avaliação do conforto de frenagem através da sensação de pedal do freio são: a força no pedal, o curso do pedal e a desaceleração do veículo. O resultado da relação destas variáveis resulta na sensação boa ou ruim de frenagem percebida pelo motorista ao dirigir um automóvel.

Numa primeira avaliação, apesar da necessidade de um refinamento com relação à modelagem desenvolvida e aplicada no programa de simulação matemática, verificou-se que a simulação matemática do sistema de freio permitiu a análise do desempenho das variáveis relacionadas ao conforto e constatou as características físicas que 
apresentam maior impacto para estas variáveis, tais como compressibilidade da pastilha para curso de pedal, assim como coeficiente de atrito para esforço de pedal. Os refinamentos necessários concentram-se basicamente nas variáveis que influenciam diretamente os resultados da absorção volumétrica do sistema de freio, que por conseqüência, atuam diretamente nos resultados do curso de pedal. Mesmo assim, os resultados da simulação matemática do sistema de freio podem ajudar em muito tanto os projetistas de sistemas de freio como àqueles que deverão adequá-lo ao veículo, pois permitem estimar o comportamento do veículo não somente sob o aspecto dinâmico da frenagem, como o comportamento esperado da sensação do pedal de freio, reduzindo o tempo e os custos de desenvolvimento e a quantidade necessária de verificações em veículo para analisarmos o nível de conforto de frenagem dos diversos automóveis.

Poderemos também alterar outras características do sistema de freio e assim analisar todas as possibilidades de alteração e/ou especificação do projeto do sistema de freio a serem necessárias visando à melhoria do conforto de frenagem do usuário. Para o estudo de caso analisado, observou-se que a mudança da pastilha original para a proposta pode ser realizada pois apresentam níveis de conforto de frenagem e desempenho similares à pastilha original, sendo esta uma das premissas consideradas para modificação do material de atrito.

Para maior refinamento do modelo matemático utilizado, seguem algumas sugestões, que oferecem continuidade ao trabalho, possivelmente, num futuro doutorado:

- Revisar o modelo matemático utilizado para simulação do curso de pedal, considerando-se as variáveis desprezadas inicialmente nas hipóteses simplificadoras que influenciavam diretamente a absorção volumétrica, e outras variáveis, tais como deformação do painel da carroceria onde é montado o conjunto servo-freio e cilindro mestre, e os cursos mortos dentro de componentes e nas suas interfaces de ligação entre os componentes;

- Revisar o modelo matemático da força de pedal, considerando as cargas das molas de 
retorno do pedal de freio, do servo-freio e do cilindro mestre, que variam de acordo com o deslocamento do pedal de freio, que resultariam em forças resistivas ao movimento do pedal;

- Implantar a modelagem matemática do sistema de freio falhado, tais como um circuito falhado ou servo-freio falhado, que são normalmente avaliados nas normas de regulamentação, para verificar o atendimento dos requisitos estabelecidos em termos de desaceleração mínima a ser atendida e máximo esforço de pedal;

- Implantar a modelagem matemática do sistema de freio para que se possa realizar a análise das curvas de distribuição de frenagem entre eixos, estabelecido nas normas regulamentadoras;

- Estender a avaliação comparativa da sensação de frenagem subjetiva versus objetiva para outros veículos concorrentes, não somente para analisar o nível de correlação entre os resultados das duas análises, mas também formar um banco de dados de projetos comparativos das diferentes políticas de conforto de frenagem, utilizados por cada montadora, como sendo um bom nível de conforto de frenagem;

Por fim, a análise objetiva da sensação de frenagem poderá auxiliar na determinação da curva de conforto de frenagem ótima para os novos desenvolvimentos de sistemas de freio, que estão evoluindo dos sistemas convencionais de acionamento hidráulico para sistemas eletrohidráulicos, denominados de "brake-by-wire" (BBW). Nestes novos sistemas, a interface existente entre o motorista e o sistema de freio do veículo passaria a ser transmitido não mais de forma mecânica, através do conjunto servo-freio e cilindro mestre, mas de forma eletro-eletrônica, através da utilização de uma unidade de atuação que possui um simulador de curso de pedal e força de pedal. 


\section{REFERÊNCIAS BIBLIOGRÁFICAS}

ASSOCIAÇÃO BRASILEIRA DE NORMAS TÉCNICAS. NBR 14353: Veículos Rodoviários - Veículos motorizados equipados com sistema antibloqueio de frenagem Medida do desempenho do freio. Rio de Janeiro: 1999. 9 p.

AUGSBURG, K. Development Tools to Assist in the Objective Description of Brake Feel. In: BREUER, B.; DAUSEND, U. Advanced Brake Technology. Warrendalle: Society of Automotive Engineers, Inc., 2003.

BASCH, R. H. et al. Correlation of Lining Properties with Brake Pedal Feel. In: $20^{\text {th }}$. Annual Brake Colloquium and Exhibition, 2002, Phoenix. Proceedings of... Warrendalle: Society of Automotive Engineers, Inc., 2002. 9 p. (SAE Technical Paper Series 2002-01-2602)

BAUER, H. (Ed.). Conventional and Electronic Braking Systems. 3. ed. Plochingen: Robert Bosch GmbH, 2003. 134 p.

BOSCH. Automotive Handbook. 6. ed. Plochingen: Robert Bosch GmbH, 2004. p. 792-837.

EBERT, D. G.; KAATZ, R. A. Objective Characterization of Vehicle Pedal Feel. In: 1994 SAE International Congress \& Exposition, 1994, Detroit. ABS/TCS and Brake Technology Developments. Warrendale: Society of Automotive Engineers, Inc., 1994. 8 p. (SAE Technical Paper Series, 940331) 
FRAS-LE. Toyota.pps: Visit of TMC - Toyota. Caxias do Sul, 2004. 1 CD-ROM. Microsoft Office PowerPoint 2003 for Windows.

GARDINALLI, G. J. Comparação do desempenho de frenagem simulada x experimental de um veículo de passeio com freios hidráulicos e ABS. 2005. f. Trabalho de Conclusão (Mestrado Profissionalizante em Engenharia Automotiva) - Escola Politécnica, Universidade de São Paulo, São Paulo, 2005.

GILLESPIE, T. D. Braking Performance. In: Fundamentals of Vehicle Dynamics. Warrendalle: Society of Automotive Engineers, Inc., 1992. p. 45-77.

HARRIES, D. A. Pedal Feel with Power Braking Systems. [S.1]: Lucas Engineering Review, p. 65-67, 1978.

HIROTA, N et al. Development of Variable Technology in Performance of Brake Booster. In: 2004 SAE World Congress, 2004, Detroit. ABS/TCS, Brake Technology and Foundation Brake NVH, and Tire and Wheel Technology. Warrendale: Society of Automotive Engineers, Inc., 2004. 7 p. (SAE Technical Paper Series, 2004-01-0724)

JURID Meß- und Prüfsysteme. Glinde: Honeywell Friction Materials Germany GmbH Disponível em: $<$ http://www.jurid.de/indexmain.php?lang=1\&content=produkt_mess_und_ pruefsysteme>. Acesso em: 03 dez. 2005. 
KAKIHARA, K.; MATSUZAKI, Y. Advanced Technology of ADVICS Opposed Piston Caliper. In: BREUER, B (Ed.). XIII International $\mu$ Symposium: Brake Conference, 2003, Bad Neuenahr. Fortschritt-Berichte... Düsseldorf: VDI Verlag GmbH, 2003. p. 99-113.

KOWALSKI, M. F.; EBERT, D. G. Establishing Brake Design Parameters for Customer Satisfaction. In: 1993 SAE International Congress and Exposition, 1993, Detroit. ABS/TCS and Brake Technology. Warrendale: Society of Automotive Engineers, Inc., 1993. 12 p. (SAE Technical Paper Series, 930799)

LIMPERT, R. Brake Design and Safety. 2. ed. Warrendalle: Society of Automotive Engineers, Inc., 1999. 525 p.

LINK Engineering Company. Plymouth: Link Engineering Company. Disponível em: $<$ http://www.linkeng.com/index.htm>. Acesso em: 03 dez. 2005.

LUCAS BRAKING Theory, Brake Actuation Equipment, Brake Pressure Control Valves and Brake Pipes and Hoses. Shirley: Lucas Automotive Ltd., 1995a. 56 p. (XFB113 (EN))

LUCAS MAINTENANCE/Repair Manual: Drum Brakes. Shirley: Lucas Automotive Ltd., 1995b. 48 p. (XQB101 (EN))

MADUREIRA, O. M. Dinâmica de Veículos: Apresentação e discussão dos fatos básicos. São Paulo: EP-USP, 2004. 56 p. 
MARKUS, F. Where Does 'Good Brake Feel' Come From? : Our techies mount a quest for grail of great brake feel. Car and Driver. Ann Arbor, p. 97-101, ago. 1999.

MITSCHKE, M.; WALLENTOWITZ, H. Dynamik der Kraftfahrzeuge. 4. ed. Berlin: Springer-Verlag, 2004. 806 p.

MORTIMER, R. G. et al. Brake Force Requirement Study: Driver - Vehicle Braking Performance as a Function of Brake System Design Variables. Ann Arbor: Highway Safety Research Institute, University of Michigan, 1970. 200 p. (Relatório técnico, HuF-6)

PASCALI, L. et al. Customer Orientation: A Further Target in Brake System Design. In: 2003 SAE World Congress, 2003, Detroit. Brake, Tire \& Wheel Technology. Warrendale: Society of Automotive Engineers, Inc., 2003. 10 p. (SAE Technical Paper Series, 2003-010599)

REIMPELL, J.; STOLL, H.; BETZLER, J. W. Braking behaviour. In: . The Automotive Chassis: Engineering Principles. 2. ed. Warrendale: Society of Automotive Engineers, Inc., 2001. p. 397-402.

SCHWANKE, W. The Datasheet Program User Manual. Version 7.1. Koblenz: TRW Automotive Koblenz, 2002. 207 p.

TRW AUTOMOTIVE. T.S. 6-11-101: Brake Pads Quality Control Euro-Spec AK-Standard. Koblenz: 1997. 41 p. 


\section{BIBLIOGRAFIA CONSULTADA:}

CAVIASSO, G. et al. Customer Orientation in Advanced Vehicle Design. In: 2002 SAE Automotive Dynamics and Stability Conference and Exhibition, 2002, Detroit. Proceedings ... Warrendale: Society of Automotive Engineers, Inc., 2002. 11 p. (SAE Technical Paper Series, 2002-01-1576)

DAIROU, V. et al. An Original Method to Predict Brake Feel: A Combination of Design of Experiments and Sensory Science. In: 2003 SAE World Congress, 2003, Detroit. Brake, Tire \& Wheel Technology. Warrendale: Society of Automotive Engineers, Inc., 2003. 9 p. (SAE Technical Paper Series, 2003-01-0598)

SHERIDAN, D. C.; CHANG, H. H. A Requirements Driven Design Methodology for a Vehicle Brake System. In: 1993 SAE International Congress and Exposition, 1993, Detroit. ABS/TCS and Brake Technology. Warrendale: Society of Automotive Engineers, Inc., 1993. 7 p. (SAE Technical Paper Series, 930800) 